\title{
Mancos Shale Literature Review on the Colorado Plateau
}

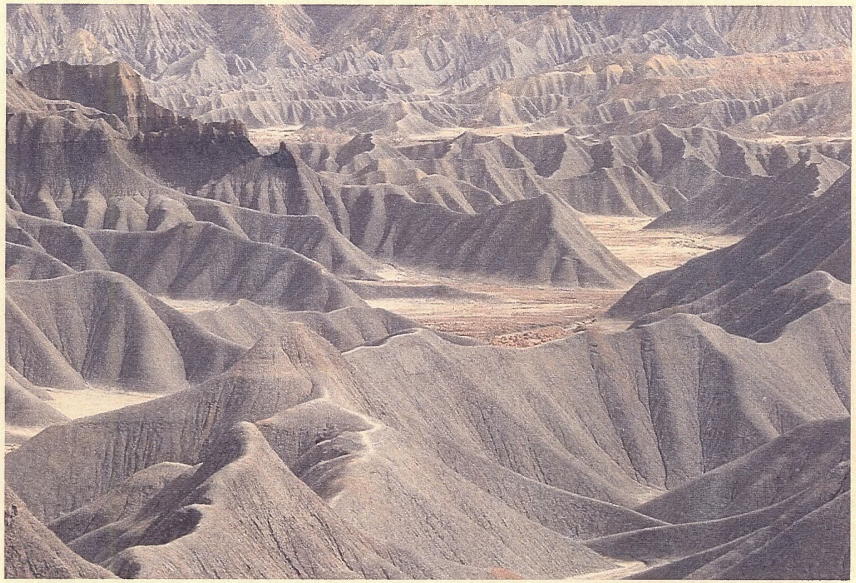

April 2005, agreement $n^{\circ}$ JSA041003

Q76.5 1a Lebron, David Chandler, and Lynn Jackson .058 I 337 thitate

2005 VERSITY

C. 2 
This publication was jointly funded by the Bureau of Land Management, Moab, UT office and Utah State University Ecology Center under agreement number JSA041003.

Front page photograph: Caineville Badlands, Blue Gate; courtesy of John C. Dohrenwend, Southwest Satellite Imaging. We gratefully acknowledge Richard Grauch, USGS, Denver, CO, for his contribution of 136 references to this review. Matt Madsen, Ecology Center, USU was instrumental in the acquisition of some of the PDF files compiled in the digital archive included as a CD ROM at the end of this report. The authors Inma Lebron and David Chandler are from Utah State University, Logan, UT; Lynn Jackson is from the Bureau of Land Management, Moab, UT. 


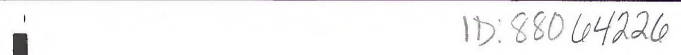

$Q H$

\section{Mancos Shale}

\section{Literature Review on \\ the Colorado Plateau}

\section{Bureau of Land Management, Moab. JSA041003. April 2005}

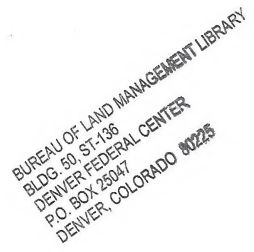

\section{Inma Lebrom. David Chandier, and Lynn Jackson}
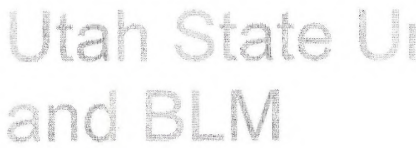
a

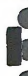

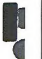

,

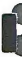

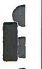

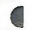

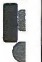

4

I

d

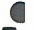

1

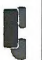

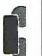

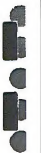

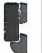

B

\&

8 


\section{Table of Contents}

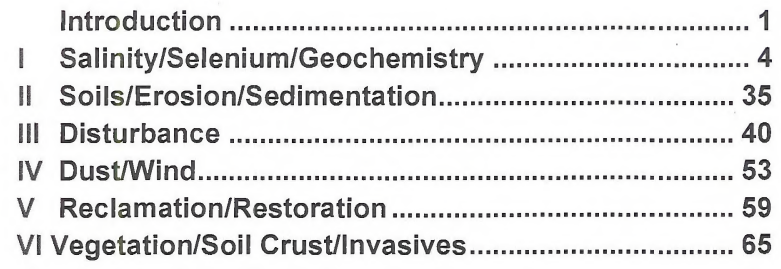




\section{INTRODUCTION}

This literature review has been prepared by Utah State University for the Bureau of Land Management under Cooperative Ecosystem Study Unit Agreement Number JSA041003. It is provided as both a hard copy and an accompanying CD-ROM. The hard copy of the Mancos Shale literature review on the Colorado Plateau is an annotated review that contains 125 references we believe pertinent to research and studies conducted on the Mancos Shale or similar types of saline, fine-grained soils on the Colorado Plateau and in the western United States. Several of the full text articles are available as PDF files on the CD-ROM, as indicated by the PDF notation after the year of publication in the hard copy reference. The CD-ROM also contains an extended literature review with almost 800 related references in EndNote format, and a WORD document of the hard copy report.

The main focus of the literature review project was to identify available information directly related to research in the Mancos Shale on the Colorado Plateau. The literature review was further focused on salinity and disturbance effects to the Mancos, in an effort to get relevant information into the hands of regional land manager's dealing with an array of management issues on Mancos landscapes.

In some instances it was difficult to determine which of the $800+$ citations should go into the hardcopy reference, and which should be relegated to the CD ROM version. It was clear that any research that dealt specifically with the Mancos Shale should go into the hard copy. The majority of these citations deal with salinity and geochemistry, and to a lesser degree the others deal principally with erosion or sedimentation. Since one of the objectives of the project was to identify research related to disturbance, dust issues and reclamation associated with the Mancos, and our review identified only minimal references for this type of research directly on the Mancos, it was decided to include additional citations that deal with disturbance, dust and reclamation in other arid western US areas, principally in the Mojave Desert.

Not placed in the hard copy report were multiple citations dealing with salinity and selenium related to agricultural lands on the Mancos since this review is focused primarily on natural landscape management issues. Additionally the hard copy list of citations does not include multiple geologic references and mineral assessment reports where the Mancos was involved, however, these citations were placed on the CD ROM. 


\section{Hard Copy Reference}

The references are organized alphabetically under six categories in the hard copy report. There are multiple citations which could appear under more than one heading, however, efforts were made to place each citation under the most appropriate heading for the paper. The categories are:

- Salinity/selenium/geochemistry

- Soils/erosion/sedimentation

- Disturbance

- Dust

- Reclamation/ restoration

- Vegetation/soil crust/invasives.

Salinity, selenium and geochemistry papers focus primarily on issues of water quality, salt transport mechanisms, speciation and dissolution paths, salt quantities and sources, effects on soils and other biota, geomorphic influences, surface runoff and erosional relationships to salt mechanics, and case examples of impact assessments.

The soil, erosion and sedimentation group has overlap with other groups, principally disturbance, however the focal point of this section considers the natural dynamics of these features as they apply to the Mancos or mancos-like formations. These papers primarily discuss water infiltration and runoff rates, sediment yield, mass movement, vegetation cover, geomorphic features and effects, and fluvial mechanics.

The facets of disturbance research presented include damage to natural soil stabilizers, soil displacement, damage to vegetation, increased mechanical erosion, soil compaction (increased bulk density), reduced soil moisture, increased soil temperature, increased runoff, increased sediment loading and effects on fauna (mammals and fish). There are multiple citations of direct measurements from various forms of disturbance on arid desert soils in the Mancos and in other areas of the southwestern US.

Dust research presented focuses primarily on characteristics of dust sources and the mechanisms of movement, influence of biotic and physical crusts in dust suppression, relationships of dust to disturbance, particle sizes, distribution and wind velocities required to move dust, nutrient input and losses to soil biota from dust, and geomorphic effects.

Reclamation and restoration citations presented in the hard copy reference primarily consider reclamation of saline soils, treatment effects on soil biota, soil amendments and effects on run-off and sediment yield, natural revegetation patterns, and a paper on the role of mycorrhizae in revegetation in arid areas. 
Vegetation, soil or microbiotic crust and invasives consider new plant species on the Mancos, the role of competition in arid environments, plant community relationships, soil characteristics and nutrient impacts related to invasive species, and a paper on the new concept of state and transition modeling of ecological sites and potential applications for management.

\section{CD-ROM}

The CD-ROM contains, in addition to the hard copy references, an extended literature review with 700 + references in EndNote format, PDF copies of more than 260 of the papers, and a WORD document of the hard copy report.

EndNote is a widely utilized bibliographic reference software in the academic and research community. BLM is currently in the process of reviewing and approving EndNote software for use on our network system. Until that occurs, we decided to prepare this hard copy report of the more pertinent citations, along with providing access to those papers with an associated PDF file.

If you have EndNote software, specific keyword searches may be performed on the complete data set in the CD-ROM with this software. The software will also link to PDF files so the full manuscript can be read. For those with the software, this linkage occurs by placing the folder with the PDF files on the $\mathrm{C}$ drive. If you wish to place the PDF folder in a different location in your computer you can do so and access to it by changing the URL address in the End Note file. 


\section{SALINITY - SELENIUM - GEOCHEMISTRY}

Apodaca, L.E. (1998 (PDF)). "Analysis of ground-water-quality data of the upper Colorado River Basin, water years 1972-92." U.S. Geological Survey WaterResources Investigations Report 97-4240.

As part of the U.S. Geological Survey's National Water-Quality Assessment program, an analysis of the existing ground-water-quality data in the Upper Colorado River Basin study unit is necessary to provide information on the historic water-quality conditions. Analysis of the historical data provides information on the availability or lack of data and water-quality issues. The information gathered from the historical data will be used in the design of groundwater-quality studies in the basin. This report includes an analysis of the groundwater data (well and spring data) available for the Upper Colorado River Basin study unit from water years 1972 to 1992 for major cations and anions, metals and selected trace elements, and nutrients. The data used in the analysis of the ground-water quality in the Upper Colorado River Basin study unit were predominantly from the U.S. Geological Survey National Water Information System and the Colorado Department of Public Health and Environment data bases. A total of 212 sites representing alluvial aquifers and 187 sites representing bedrock aquifers were used in the analysis. The available data were not ideal for conducting a comprehensive basin wide water quality assessment because of lack of sufficient geographical coverage. Evaluation of the groundwater data in the Upper Colorado River Basin study unit was based on the regional environmental setting, which describes the natural and human factors that can affect the water quality. In this report, the groundwater-quality information is evaluated on the basis of aquifers or potential aquifers (alluvial, Green River Formation, Mesaverde Group, Mancos Shale, Dakota Sandstone, Morrison Formation, Entrada Sandstone, Leadville Limestone, and Precambrian) and land-use classifications for alluvial aquifers. Most of the ground-water-quality data in the study unit were for major cations and anions and dissolved-solids concentrations. The aquifer with the highest median concentrations of major ions was the Mancos Shale. The U.S. Environmental Protection Agency secondary maximum contaminant level of 500 milligrams per liter for dissolved solids in drinking water was exceeded in about 75 percent of the samples from the Mancos Shale aquifer. The guideline by the Food and Agriculture Organization of the United States for irrigation water of 2,000 milligrams per liter was also exceeded by the median concentration from the Mancos Shale aquifer. For sulfate, the U.S. Environmental Protection Agency proposed maximum contaminant level of 500 milligrams per liter for drinking water was exceeded by the median concentration for the Mancos Shale aquifer. A total of 66 percent of the sites in the Mancos Shale aquifer exceeded the proposed maximum contaminant level. Metal and selected trace-element data were available for some sites, but most of these data also were below the detection limit. The median concentrations for iron for the selected aquifers and land-use classifications were below the U.S. Environmental Protection Agency secondary maximum contaminant level of 300 micrograms per liter in drinking water. Median concentration of manganese for the Mancos Shale exceeded the U.S. Environmental Protection Agency secondary maximum contaminant level of 50 micrograms per liter in drinking water. The highest selenium concentrations were in the alluvial aquifer and were associated with rangeland. However, about 22 
percent of the selenium values from the Mancos Shale exceeded the U.S. Environmental Protection Agency maximum contaminant level of 50 micrograms per liter in drinking water. Few nutrient data were available for the study unit. The only nutrient species presented in this report were nitrate-plus-nitrite as nitrogen and orthophosphate. Median concentrations for nitrate-plus-nitrite as nitrogen were below the U.S. Environmental Protection Agency maximum contaminant level of 10 milligrams per liter in drinking water except for 0.02 percent of the sites in the alluvial aquifer and 0.03 percent of the sites in the Mancos Shale. Concentrations of orthophosphate did not vary significantly among aquifers or land-use classifications. Historic water-quality data from wells and springs helped to characterize the regional distribution of ground-water quality information in the Upper Colorado River Basin study unit. The historical ground-water data summarized in this report will be used in the design of a groundwater-quality network. Because ground-water quality issues in the study unit are related to high dissolved solids, sulfate, selenium, and nutrients, this report discusses some of the important findings related to these issues.

Azimi, Z.A. and C.J. Duffy (1993). "Modeling transport of subsurface salinity from a Mancos Shale hillslope." Ground Water 31(6): 972-981.

In the Upper Colorado River Basin, irrigated agriculture is associated with increasing stream salinity. In areas targeted for control of salinity transport to streams, as much as $90 \%$ of stream salinity has been estimated to originate from ground water flowing through salt-bearing stratum. Primary salt sources are the marine shales and the shale residuum that underlie the soils throughout much of the basin. Shallow subsurface flow systems, created by seepage from canals and deep percolation of irrigation water, are believed to be the primary agents leaching the salts from underlying shale deposits and carrying them to streams. This study attempts to determine the relative importance of advective, dispersive, and diffusive salt transport processes from the alluvium covered, shale hillslopes of the region. The results of various irrigation management schemes for appraising the possibility of controlling salt loading to streams are presented.

Bauch, N.J. and N.E. Spahr (1998). "Salinity trends in surface waters of the upper Colorado River Basin, Colorado." Journal of Environmental Quality 27(3): 640-655.

Dissolved-solids data collected in the Upper Colorado River Basin upstream from Cameo, Colorado, and in the Gunnison River Basin were analyzed for trends in flow-adjusted dissolved-solids concentrations and loads for water years 1970 to 1993,1980 to 1993 , and 1986 to 1993 . Trend results for flow-adjusted periodic dissolved-solids concentrations for the Colorado River Basin upstream from Cameo, $\mathrm{CO}$, generally were downward or no trend was indicated. Trends in flowadjusted monthly and annual dissolved-solids loads primarily were downward or absent. These trend results partly agree with the downward trends reported by a previous investigation for the Colorado River near Cameo site. In the Gunnison River Basin, trends in flow-adjusted dissolved-solids concentrations and loads were not detected for more than one-half of the site/analysis-period combinations. Of the trends that were present, most indicated decreases in concentrations and loads rather than increases. In both the Colorado River Basin upstream from Cameo, CO, and the Gunnison River Basin, trends in flowadjusted dissolved-solids concentrations and flow-adjusted monthly and annual 
dissolved-solids loads may be affected by a variety of factors. These include channel evolution and hydrologic variation, water quality and flow rate of groundwater discharges and springs, sample size and period of record of dissolved-solids data, and changes in land use in the basin.

Benhur, M.,P. Clark and J. Letey (1992). "Exchangeable Na, polymer, and waterquality effects on water infiltration and soil loss." Arid Soil Research and Rehabilitation 6(4): 311-317.

Increasing exchangeable sodium percentage (ESP) contributes to increased soil dispersion and swelling of clay, which reduces the infiltration rate and increases run off. Synthetic polymers are available that may decrease soil dispersion. A study was conducted to determine the effect of three polymers dissolved in water at 10 or $50 \mathrm{mg} \mathrm{L}-1$ concentrations and applied through a rainfall simulator on the infiltration rate, erosion, and soil migration through the layer of a soil at ESP equal to 8.5 and 30.6 The polymers were a cationic polysaccharide and two anionic polyacrylamides with different negative charge densities. The infiltration rate decreased with time and approached a final steady-state infiltration rate (FIR). The runoff water and associated sediment were captured and measured. Water coming through the soil layer and the amount of particulates contained in the water were measured. The FIR was significantly lower for the soil at ESP equal to 30.6 than at ESP equal to 8.5. There was no statistically significant effect of the polymer type or concentration on FIR. The amount of soil loss through erosion was significantly affected by the soil ESP, polymer type, and polymer concentration of the polymer application. More soil was in the runoff for the higher ESP than for the lower ESP The polymer treatment effects on soil loss were in the following order: cationic polysaccharide > untreated > low anionic PAM > higher-charged anionic PAM. Soil loss from application of the polymer at $50 \mathrm{mg} \mathrm{L}-1$ was significantly less than at $10 \mathrm{mg} \mathrm{L}-1$. The amount of soil migrating through the soil layer with the percolate was significantly higher for the higher ESP soil, whereas there was no significant effect of polymer treatment on this parameter.

Butler, D.L., W.G. Wright, K.C. Stewart, B.C. Osmundson, R.P. Krueger, and D.W. Crabtree (1993). "Detailed study of selenium and other constituents in water, bottom sediment, soil, alfalfa and biota associated with irrigation drainage in the Uncompahgre project area and in the Grand Valley, west-central Colorado, 1991-93." Sources and fate of pollution.

In 1985, the U.S. Department of the Interior began a program to study the effects of irrigation drainage in the Western United States. These studies were done to determine whether irrigation drainage was causing problems related to human health, water quality and fish and wildlife resources. Results of a study in 199193 of irrigation drainage associated with the Uncompahgre Project area, located in the lower Gunnison River Basin and of the Grand Valley, located along the Colorado River, are described in this report. The focus of the report is on the sources, distribution, movement and fate of selenium in the hydrologic and biological systems and the effects on biota. Generally, other trace-constituent concentrations in water and biota were not elevated or were not at levels of concern. Soils in the Uncompahgre Project area that primarily were derived from Mancos Shale contained the highest concentrations of total and waterextractable selenium. Only 5 of 128 alfalfa samples had selenium concentrations 
that exceeded a recommended dietary limit for livestock. Selenium data for soil and alfalfa indicate that irrigation might be mobilizing and redistributing selenium in the Uncompahgre Project area. Distribution of dissolved selenium in ground water is affected by the aqueous geochemical environment of the shallow ground-water system. Selenium concentrations were as high as 1,300 micrograms per liter in water from shallow wells. The highest concentrations of dissolved selenium were in water from wells completed in alluvium overlying the Mancos Shale of Cretaceous age; selenium concentrations were lower in water from wells completed in Mancos Shale residuum. Selenium in the study area could be mobilized by oxidation of reduced selenium, adsorption from aquifer sediments, ion exchange and dissolution. Infiltration of irrigation water and, perhaps nitrate, provide oxidizing conditions for mobilization of selenium from alluvium and shale residuum and for transport to streams and irrigation drains that are tributary to the Gunnison, Uncompahgre and Colorado Rivers. Selenium concentrations in about 64 percent of water samples collected from the lower Gunnison River and about 50 percent of samples from the Colorado River near the Colorado-Utah State line exceeded the U.S. Environmental Protection Agency criterion of 5 micrograms per liter for protection of aquatic life. Almost all selenium concentrations in samples collected during the no irrigation season from Mancos Shale areas exceeded the aquatic-life criterion. The maximum selenium concentrations in surface-water samples were 600 micrograms per liter in the Uncompahgre Project area and 380 micrograms per liter in the Grand Valley. Irrigation drainage from the Uncompahgre Project and the Grand Valley might account for as much as 75 percent of the selenium load in the Colorado River near the Colorado-Utah State line. The primary source areas of selenium were the eastern side of the Uncompahgre Project and the western one-half of the Grand Valley, where there is extensive irrigation on soils derived from Mancos Shale. The largest mean selenium loads from tributary drainages were 14.0 pounds per day from Loutzenhizer Arroyo in the Uncompahgre Project and 12.8 pounds per day from Reed Wash in the Grand Valley. Positive correlations between selenium loads and dissolved-solids loads could indicate that salinitycontrol projects designed to decrease dissolved-solids loads also could decrease selenium loads from the irrigated areas. Selenium concentrations in irrigation drainage in the Grand Valley were much higher than concentrations predicted by simple evaporative concentration of irrigation source water. Selenium probably is removed from pond water by chemical and biological processes and incorporated into bottom sediment. The maximum selenium concentration in bottom sediment was 47 micrograms per gram from a pond on the eastern side of the Uncompahgre Project. Selenium concentrations in some aquatic plants and aquatic invertebrates exceeded a dietary guideline of 3 micrograms per gram dry weight for protection of fish and wildlife resources. More than 75 percent of whole-body fish samples collected from rivers and tributaries throughout the study area had selenium concentrations that exceeded the 1984 National Contaminant Biomonitoring Program 85th-percentile concentration of 0.73 microgram per gram wet weight. Whole-body fish samples from the Gunnison River had significantly higher geometric mean selenium concentrations than fish samples from the Uncompahgre and Colorado Rivers. Based on a risk assessment using selenium data for five Grand Valley streams, the selenate form of selenium could be a moderate risk to the swim-up life stage (less than 99 days old) of the endangered Colorado squawfish and to three tested life stages of the endangered razorback sucker. Zinc concentrations in Adobe Creek, Leach Creek 
and Indian Wash were in the high-risk category for the swim-up life stage of Colorado squawfish. Selenium concentrations in food items of migratory birds collected at wetlands in the Uncompahgre Project area exceeded the dietary guideline for protection of consumer wildlife. Fathead minnows from ponds had high selenium concentrations and the maximum concentration was 110 micrograms per gram dry weight. Selenium concentrations in bird eggs and livers generally were in the range of uncertainty regarding biological risk; however, some samples from the Uncompahgre Project area had selenium concentrations in the high-risk category. Of 65 bird eggs incubated, only one had any visual deformity. Five recently hatched birds and two embryos that were found dead at two ponds in the Uncompahgre Project area had selenium concentrations ranging from 19 to 43 micrograms per gram dry weight, but no abnormalities or deformities were observed. Toxicity tests on irrigation-drainage water from five Grand Valley streams indicated no significant toxicity differences between control and test samples, except for the test on fathead minnows exposed to water from Leach Creek. Bioaccumulation of selenium from water to biota was significant in the study area and the highest bioaccumulation factor was about 20,900 from water to bird livers. Selenium accumulates in fish and birds in the study area to levels that would limit human consumption if eaten on a daily basis. It is unlikely that fish and birds taken in the study area are consumed by humans on a daily basis.

Butler, D.L., R.P. Krueger, B.C. Osmundson, and E.G. Jensen (1994). "Reconnaissance investigation of water quality, bottom sediment, and biota associated with irrigation drainage in the Dolores Project Area, southwestern Colorado and southeastern Utah, 1990-91." US Geological Survey, Earth Science Information Center, open-file reports section, Box 25286, MS 517. Denver, CO 80225 (USA), 1994, 126 pp.

Water, bottom-sediment, and biota samples were collected in 1990-91 to identify water-quality problems associated with irrigation drainage in the Dolores Project area. Concentrations of cadmium, mercury, and selenium in some water samples exceeded aquatic-life criteria. Selenium was associated with irrigation drainage from the Dolores Project, but other trace elements may be transported into the area in the irrigation water supply. Selenium concentrations exceeded the chronic aquatic-life criterion in water samples from lower McElmo Creek and Navajo Wash, which drain the Montezuma Valley, from newly irrigated areas, and from the Mancos River. The maximum selenium concentration in water was 88 micrograms per liter from Navajo Wash. Concentrations of herbicides in water were less than concentrations harmful to aquatic life. Selenium concentrations in four bottom-sediment samples exceeded the baseline concentrations for soils in the Western United States. The largest selenium concentrations in biota were in samples from Navajo Wash, from newly irrigated areas north of the Montezuma Valley, and from the Mancos River basin. Selenium concentrations in aquaticinvertebrate samples from the newly irrigated areas exceeded a guideline for food items consumed by fish and wildlife. Selenium concentrations in whole-body suckers were larger in the San Juan River downstream from the Dolores Project than upstream from the project at Four Corners. Selenium concentrations in fathead minnow samples from two sites were at adverse-effect levels. Mercury concentrations in warm-water game fish in reservoirs in the study area may be of concern to human health. Some concentrations of other trace elements 
exceeded background concentrations, but the concentrations were not toxicologically significant or the toxicologic significance is not known.

Butler, D.L., B.C. Osmundson, and R.P. Krueger (1994). "Field screening of water, soil, bottom sediment and biota associated with irrigation drainage in the Dolores Project and the Mancos River Basin, southwestern Colorado." USGS Water-Resources Investigations Report. $43 \mathrm{pp}$. Available from the U.S. Geological Survey, Branch of Information Services, Box 25286, Mail Stop 517, Denver Federal Center, Denver, CO 80225 (USA).

A reconnaissance investigation for the National Irrigation Water Quality Program in 1990 indicated elevated selenium concentrations in some water and biota samples collected in the Dolores Project in southwestern Colorado. High selenium concentrations also were indicated in bird samples collected in the Mancos Project in 1989. In 1994, field screenings were done in parts of the Dolores Project and Mancos River Basin to collect additional selenium data associated with irrigation in those areas. Selenium is mobilized from soils in newly irrigated areas of the Dolores Project called the Dove Creek area, which includes newly (since 1987) irrigated land north of Cortez and south of Dove Creek. Selenium was detected in 18 of 20 stream samples and the maximum concentration was 12 micrograms per liter. The Dove Creek area is unique compared to other study areas of the National Irrigation Water Quality Program because selenium concentrations probably are indicative of initial leaching conditions in a newly irrigated area. Selenium concentrations in nine shallow soil samples from the Dove Creek area ranged from 0.13 to 0.20 micrograms per gram. Selenium concentrations in bottom sediment from six ponds were less than the level of concern for fish and wildlife of 4 micrograms per gram. Many biota samples collected in the Dove Creek area had elevated selenium concentrations when compared to various guidelines and effect levels, although selenium concentrations in water, soil and bottom sediment were relatively low. Selenium concentrations in 12 of 14 aquatic- invertebrate samples from ponds exceeded 3 micrograms per gram dry weight, a dietary guideline for protection of fish and wildlife. The mean selenium concentration of 10.3 micrograms per gram dry weight in aquatic bird eggs exceeded the guideline for reduced hatchability of 8 micrograms per gram dry weight. Two ponds in the Dove Creek area had a high selenium hazard rating based on a new protocol for assessing selenium hazard in the environment; however, waterfowl were reproducing at the two ponds. Three tributary streams of Mc Elmo Creek that drain irrigated areas of the Montezuma Valley south of the creek were sampled in 1994. Mud Creek probably is the largest source of selenium to Mc Elmo Creek. Most biota samples from Mud Creek had elevated selenium concentrations when compared to guidelines for dietary items and freshwater fish. Selenium concentrations in water samples collected in the Mancos River Basin upstream from Navajo Wash, which includes the Mancos Project, ranged from less than 1 to 10 micrograms per liter. Mud Creek contributed about 74 percent of the selenium load to the upper Mancos River in March 1994. Selenium concentrations were much higher in Navajo Wash; a sample collected in March had 97 micrograms per liter of selenium. Bottom-sediment samples from two ponds in the Mancos Project exceeded the concentration of concern of 4 micrograms per gram. The highest selenium concentrations in biota samples from streams in the Mancos River Basin were for samples from Navajo Wash. Most concentrations in biota in the 
upper Mancos River Basin were less than guidelines. Mean selenium concentrations in eggs from aquatic birds collected at three ponds in the Mancos Project slightly exceed the guideline associated with reduced hatchability. Five bird livers had a mean selenium concentration of 32.6 micrograms per gram dry weight, which slightly exceeded the mean concentration of 30 micrograms per gram dry weight that is associated with reproductive impairment. Two of the ponds had a high selenium hazard rating; however, mallard reproduction was observed in 1994 at one of the ponds that had a high selenium-hazard rating.

Butler, D.L. and P. von Gerard (1996 (PDF)). "Salinity in the Colorado River in the Grand Valley, Western Colorado, 1994-95." US Geological Survey, Fact Sheet FS-215-96.

Salinity, or the dissolved-solids concentration, is the measure of salts such as sodium chloride, calcium bicarbonate, and calcium sulfate that are dissolved in water. About one-half of the salinity in the Colorado River Basin is from natural sources (U.S. Department of the Interior, 1995), such as thermal springs in the Glenwood-Dotsero area, located about 90 miles upstream from Grand Junction. Effects of human activities, such as irrigation, reservoir evaporation, and transbasin diversions, have increased the levels of salinity in the Colorado River. High salinity can cause lower crop yields by reducing water and nutrient uptake by plants and can increase agricultural production costs because of higher leaching and drainage requirements. Agricultural losses might occur when salinity reaches about 700-850 milligrams per liter (U.S Department of the Interior, 1994). The Colorado River is the major source of irrigation water to the Grand Valley and also is one source of water for the Clifton Water District, which supplies domestic water to part of the eastern Grand Valley. During spring and early summer in 1994, the Colorado River in the Grand Valley had lower than average streamflow. There was concern by water users about the effect of this low Streamflow on salinity in the river. In 1994, the U.S. Geological Survey (USGS), in cooperation with the Colorado River Water Conservation District, began a study to evaluate salinity in the Colorado River. Salinity in the Colorado River in 1994-95 was dependent to varying degrees on streamflow. The less than average runoff in 1994 probably caused unusually high salinity in the Colorado River in July 1994. However, salinity in the Colorado River for August through November 1994 was not unusual when compared to historical data that have been collected at the Cameo and State line gauging stations. Reservoir releases in the Colorado River Basin upstream from the Grand Valley augmented river flows with dilute water and partially offset the f low natural streamflow on salinity. The high and prolonged runoff in 1995 seemed to have affected salinity in the Colorado River more noticeably than the low-flow period of 1994. Salinity in July and August 1995 was much lower than in July and August 1994 at six sampling sites on the Colorado River from Cameo to the Colorado-Utah State line. Salinity during July-October 1994 near the diversion points on the Colorado River for the Government Highline Canal and Grand Valley Canal did not exceed a threshold level at which crop productivity may be adversely affected. Salinity increased in the Colorado River from Palisade (site 2) to the Gunnison River (site 5) and from the Redlands Parkway (site 6, downstream from the Gunnison River to the Colorado-Utah State line (site 8 ) because of salt loading from surface and subsurface irrigation return flows. During 1994-95, the highest salinity in the Colorado River between the Redlands Parkway and the State line occurred 
during August-November of 1994 , which probably coincides with the maximum salt loading to the river from irrigation drain water and return flows.

Butler, D.L. (2001 (PDF)). "Effects of piping irrigation laterals on selenium and salt loads, Montrose Arroyo Basin, Western Colorado." U.S Geological Survey Water-Resources Investigations Report 01-4204.

Selenium and salinity are water-quality issues in the Upper Colorado River Basin. Certain water bodies in the lower Gunnison River Basin, including the lower Gunnison River and the Uncompahgre River, exceed the State standard for selenium of 5 micrograms per liter. Remediation methods to reduce selenium and salt loading in the lower Gunnison River Basin were examined. A demonstration project in Montrose Arroyo, located in the Uncompahgre River Basin near Montrose, was done during 1998-2000 to determine the effects on selenium and salt loads in Montrose Arroyo from replacing 8.5 miles of openditch irrigation laterals with 7.5 miles of pipe. The participants in the project were the National Irrigation Water Quality Program, the Colorado River Basin Salinity Control Program, the Uncompahgre Valley Water Users Association, and the U.S. Geological Survey. The placing of five laterals in pipe significantly decreased selenium loads in Montrose Arroyo. The selenium load at the outflow monitoring site was about 194 pounds per year less (28-percent decrease) in the period after the laterals were placed in pipe. More than 90 percent of the decrease in selenium load was attributed to a decrease in ground-water load. Salt loads also decreased because of the lateral project, but by a smaller percentage than the selenium loads. The salt load at the outflow site on Montrose Arroyo was about 1,980 tons per year less in the post-project period than in the preproject period. All of the effects of the demonstration project on selenium and salt loads probably were not measured by this study because some of the lateral leakage that was eliminated had not necessarily discharged to Montrose Arroyo upstream from the monitoring sites. A greater decrease in selenium loads relative to salt loads may have been partially the result of decreases in selenium concentrations in ground water in some areas.

Butler, D.L., and K.J. Leib (2002 (PDF)). "Characterization of selenium in the lower Gunnison River Basin, Colorado, 1988-2000." USGS Water-Resources Investigations Report. 02-4151, 30p.

Selenium concentrations in certain water bodies in the lower Gunnison River Basin, including the lower Gunnison River and lower Uncompahgre River, have exceeded the Colorado water-quality standard of 5 micrograms per liter for selenium. A task force was formed in 1998 that consists of various government agencies, private irrigation companies, and local residents to address the selenium concerns in the lower Gunnison River Basin. The task force, working with the National Irrigation Water Quality Program, needed more detailed information on selenium loading in the basin to develop viable alternatives for remediating selenium in the lower Gunnison River Basin. In 1999-2000, the U.S. Geological Survey collected selenium data for tributaries of the Gunnison River downstream from the North Fork of the Gunnison and in the North Fork Basin. The largest selenium load in a tributary stream was in the Uncompahgre River, which accounted for about 38 percent of the selenium load in the Gunnison River at Whitewater. The North Fork of the Gunnison River accounted for about 7 percent of the selenium load in the Gunnison River. Two tributaries east of Delta, 
Sunflower Drain and Bonafide Ditch, consist primarily of irrigation return flows and were other major selenium sources to the Gunnison River. Some tributaries in the lower North Fork Basin had selenium concentrations exceeding 5 micrograms per liter. Except for several streams draining the Uncompahgre Plateau, many tributaries to the Gunnison River downstream from the North Fork had selenium concentrations exceeding 5 micrograms per liter. Except during occasional rain and snowmelt events, selenium loading from nonirrigated desert areas was minimal. Detailed characterization studies were done in 1999-2000 on Cedar Creek and Loutzenhizer Arroyo, which contribute the largest tributary selenium loads to the Uncompahgre River. Selenium concentrations in Cedar Creek downstream from Miguel Road ranged from 12 to 28 micrograms per liter in November 1999. Montrose Arroyo was the largest selenium source to Cedar Creek. On an annual basis, about 20 percent of the selenium load in Cedar Creek originates in the basin upstream from Miguel Road. Selenium concentrations in Loutzenhizer Arroyo ranged from 157 to 347 micrograms per liter in February 2000. A significant increase in selenium concentrations occurred in the stream reach between the Selig Canal and Falcon Road (LZU7). Although selenium concentrations in the west tributary of Loutzenhizer Arroyo were lower than in the main stem, the west tributary contributed about 41 percent of the selenium load. Downstream from the confluence with the west tributary to the mouth, selenium concentrations in the arroyo gradually decreased, and the increase in selenium load in the lower reach was small.

Dane, J.H. and A. Clute (1977 (PDF)). "Salt effects on the hydraulic properties of a swelling soil." $42 \mathrm{nd}$ annual meeting, Soil Science Society of America, Chicago, III. United States, Dec. 3-8, 1978, Soil Science Society of America Journal 41(6): 1043-1049.

The effects of soil solution composition on the hydraulic conductivity $(K)$ and the volumetric soil solution content were measured with mixed $\mathrm{NaCl}-\mathrm{CaCl} 2$ solutions. The total electrolyte concentration (C) and the sodium adsorption ratio (SAR) characterized the applied solutions. Steady-state flow cells were constructed with provision for (i) measurement of the volumetric flux of the solution phase during saturated and unsaturated flow conditions, (ii) measurement of the volumetric soil solution content by gamma attenuation, (iii) tensiometers for hydraulic gradient and pressure head (h) measurement, (iv) application of an external load on the soil, and ( $v$ ) measurement of bulk volume changes. Soil samples were subjected to sequences of solutions varying in $C$ from $1,000 \mathrm{meq} / \mathrm{liter}$ to $10 \mathrm{meq} / \mathrm{liter}$ at constant SAR values of $0,5,15,25$, and 40 , respectively. Hydraulic conductivity decreases occurred during the first sequence of decreasing $C$ at fixed SAR values equal to or $>5$. The higher the SAR value, the greater the decrease in $\mathrm{K}$ with decreasing $\mathrm{C}$. The $\mathrm{K}$ decreases at all volumetric soil solution contents within the range of experimental data. Increases in volumetric soil solution content, at given $\mathrm{h}$ values, and decreases in bulk density, occurred simultaneously with the decreases in $\mathrm{K}$. Greater changes in $\mathrm{K}$ and water content, and smaller changes in bulk density occurred in the soil subjected to a higher external load. The $\mathrm{K}$ and bulk density, decreases and the water content increases were to a great extent irreversible, i.e. when $C$ was subsequently increased at a fixed SAR value, $K$, bulk density, and water content did not regained their initial values. Substantial increases in $\mathrm{K}$ were obtained, however, if the soil was air dried, sieved, and repacked into the flow cell. 
Deacon, J.R., and V.C. Stephens (1998 (PDF)). "Trace elements in streambed sediment and fish liver at selected sites in the upper Colorado River Basin, Colorado,1995-96." U.S. Geological Survey Water-Resources Investigations Report 98-4124.

Trace elements were analyzed in streambed-sediment samples collected from 16 sites and in fish-liver samples collected from 14 sites in the Upper Colorado River Basin in Colorado as part of the National Water-Quality Assessment program. Sites sampled represented agricultural, mining, mixed, and urban/recreation land uses and background conditions. The results for 15 trace elements in streambedsediment and in fish-liver samples are presented in this report. Fourteen of the selected trace elements were detected in streambed-sediment samples collected at all sites. Twelve of the selected trace elements were detected in fish liver at more than 50 percent of the sites. Cadmium, copper, selenium, and zinc were selected for a more detailed analysis. Cadmium, copper, and zinc concentrations in streambed sediment were highest at mining land-use sites in the Southern Rocky Mountains physiographic province. Selenium concentrations in streambed sediment were highest at an agricultural land-use site in the Colorado Plateau physiographic province. The concentration of trace elements in streambed sediment generally increased as particle size decreased. Concentrations of trace elements in fish liver generally did not follow the same relation to land use as concentrations in streambed sediment; however, cadmium concentrations in fish liver were highest at a mining land-use site in the Southern Rocky Mountains physiographic province, and selenium concentrations in fish liver were highest at an agricultural land-use site in the Colorado Plateau physiographic province. Copper and zinc concentrations in fish liver were highest at mixed land-use sites. Comparison of streambed-sediment and fish-liver concentrations to two other similar NAWQA studies in the Rocky Mountain region generally indicated similar patterns in relation to land use for streambed sediment, but not for fish liver. Cadmium, copper, and zinc concentrations in streambed sediment were highest at sites affected by mining in all three study units. Selenium concentrations in streambed sediment did not indicate relations among the three study units when compared to land use. Cadmium in fish liver was highest at sites affected by mining in all three study units. Copper, selenium, and zinc in fish liver did not indicate relations among the three study units when compared to land use.

Deacon, J.R., S.V. Mize, and N.E. Spahr (1999 (PDF)). "Characterization of selected biological, chemical, and physical conditions at fixed sites in the upper Colorado River Basin, Colorado, 1995-98." Water Resources Investigations Report 99-4181 U.S Geological Survey.

Biological community samples were collected at 15 sites in the Upper Colorado River Basin (UCOL) in Colorado as part of the National Water-Quality Assessment (NAWQA) Program. Sites sampled in two physiographic provinces, the Southern Rocky Mountains and the Colorado Plateau, represented agriculture, mining, urban and recreation, and mixed land uses and background conditions. Nine measures of water quality, which include information on nutrients, specific conductance (a surrogate for salinity), trace elements in streambed sediment, pesticides in fish tissue, fish communities, and macroinvertebrate richness and composition and stream habitat were used for comparisons among sites within the two physiographic provinces. Sampling sites from three other NAWQA study units- the Rio Grande Valley, the South Platte 
River Basin, and the Upper Snake River Basin study units-were categorized on the basis of land use and stream size in order to develop a larger data set for comparison to sites in the UCOL. Three categories of land use-forested (includes mining, urban and recreation, and background), agriculture, and mixed-were used for comparison to the UCOL fixed sites. Results indicated that all sites other than the Colorado River below Baker Gulch (a background site) showed some water-quality characteristics to be significantly affected. Results indicated that the concentrations of cadmium and zinc in streambed sediment at mining land-use sites in the Southern Rocky Mountains physiographic province generally were orders of magnitude higher than streambed-sediment concentrations at the background site. Streambed-sediment concentrations at mining land-use sites in the UCOL were greater than the 75th percentile of concentrations from sites in the three other NAWQA study units. Fish communities and habitat conditions were degraded at mining land-use sites compared to the background site. Ephemeroptera, Plecoptera, and Trichoptera (EPT) richness and the percentage of EPT were lower at mining land-use sites than at the background site and were less than the 50th percentile of those for sites from the three other NAWQA study units. Nutrient concentrations at urban and recreation sites in the Southern Rocky Mountain physiographic province generally were greater than concentrations at the background site and generally were between the 25th and 90th percentile of concentrations for sites from the three other NAWQA study units. Habitat conditions and fish communities at urban and recreation sites were slightly degraded compared to the background site. EPT richness and the percentage of EPT were lower at urban and recreation sites than at the background site and were between the 25 th and 75 th percentile of those for sites from the three other NAWQA study units. The percentage of Chironomidae, which may be indicative of pollutant-tolerant organisms, was higher at urban and recreation sites than at the background site. Mixed land-use sites in the Southern Rocky Mountains physiographic province had similar 2 Characterization of Selected Biological, Chemical, and Physical Conditions at Fixed Sites in the Upper Colorado River Basin, Colorado, 1995-98 nutrient concentrations and similar cadmium and zinc streambed-sediment concentrations. Fish community degradation index values were very different among the three mixed land-use sites in the Southern Rocky Mountains physiographic province. Larger percentages of omnivores and anomalies such as lesions and deformities at two mixed land-use sites resulted in higher degradation values of the fish community. Agriculture land-use sites had higher concentrations of nutrients and selenium than the background site in the Colorado Plateau physiographic province. Concentrations of p,p'-DDE in fish tissue at agriculture sites were higher than the 75 th percentile of concentrations for sites from the three other NAWQA study units. Fish communities had degradation values near the 75 th percentile for agriculture sites. The percentage of EPT was low at agriculture sites when compared to the background site. Two mixed land-use sites in the Colorado Plateau physiographic province had similar concentrations of nutrients, selenium, and p,p'-DDE, and similar EPT richness and composition. These two sites were located downstream from agricultural and urban activities. Some water quality measures at these two sites indicated degradation compared to a mixed land-use site upstream from most of the agriculture and urban activities in the Colorado Plateau physiographic province. 
Deyo, A. E. (1984 (PDF)). "Salinity investigations of Mancos landforms and springs in the upper Colorado River Basin." University of California, Davis. Davis, CA, United States. PhD.184p.: 184

This investigation was aimed at assessment of the potential contribution of dissolved mineral salts to the Colorado River by representative watersheds in the Upper Colorado River Basin. The Mancos, Sego and Mount Garfield formations, which were formed in the late Cretaceous Mancos Sea, are identified as important contributions of soluble salts. The occurrence of springs within the study area is highly localized, resulting in significant differences in water quality and discharge between nearly identical watersheds. In some areas the springs reach salinity levels of $80 \mathrm{dSm}-1$. It was determined that the predominance of the salts leave the watershed by groundwater flow through buried stream channels. Salt efflorescence associated with Mancos springs contain ten different $\mathrm{Ca}, \mathrm{Na}$, and $\mathrm{Mg}$ sulfate evaporite species. Four additional evaporites were identified associated with the Sego and Mount Garfield springs. The hydrated sulfates of $\mathrm{Na}$ and $\mathrm{Mg}$, as very labile salts, are subject to change in response to relatively minor changes in temperature and moisture. The Mancos landforms are interrelated by an erosional cycle that is initiated by a lowering of the local base level. During the cycle, previously stable non-saline pediment surfaces are initially dissected to form steeply sloping saline badlands. As the local relief decreases through erosion, soils form, surface salinity decreases and the rate of erosion decreases. Erosion and leaching continue until the landscape becomes graded to the local base level, forming a new planation or pediment surface with electrical conductivity levels $1 / 20$ that of the sloping Mancos badlands. To decrease the salinity contributions from the wild lands requires a multi-level approach. It is proposed that: 1) good quality ground water be intercepted and used locally or transported past highly saline areas; 2) saline groundwater, which reaches as high as $80 \mathrm{dSm}-1$, be intercepted and transported to evaporation ponds; and 3) erosion resulting in sediment and salt production be controlled through use of gully plugs and sediment retention dams, reversing the present dissection of the pediments. This program would decrease erosion, sediments yield and salt yield while increasing wild land water and vegetation.

Duffy, C., J.J. Jurinak, S. Korom, P. Corey (1989). "Groundwater investigation of SO4(2-) diffusion from a Cretaceous shale hillslope: upper Colorado River basin." Available from National Technical Information Service, Springfield VA 22161 as PB90-129156/AS. Completion Report, September 1989. 150p, 35 fig, 40 ref, 4 append. USGS Contract 14-08-0001-G1308.

This research examines the role of advection, diffusion, and dispersion in the generation and transport of groundwater salinity from hillslopes to streams of the Upper Colorado River Basin. The study coordinated field experiments and theoretical-computer experiments to gain insight into the way that subsurface salinity fronts are mobilized and transported from hillslopes of the region, and to better understand the mechanics of the groundwater system within surficial deposits which generate the observed accumulation of salinity in the Colorado River system. The field situation is that excess irrigation water from snowmelt runoff infiltrates, generates a shallow saturated zone and ultimately produces stream salinization as return flow. The following two mechanisms are proposed: (1) The formation of a shallow aquifer and accelerated displacement of salts from alluvial sediments on the lower portion of hillslopes. This displacement is a 
natural consequence of excess irrigation and canal seepage. (2) The diffusion of saline pore fluids from a low permeability marine shale which underlies the shallow aquifer. Since the marine, Mancos Shale, underlies most of the irrigated land of the basin, the potential for diffusive salt loading from this formation constitutes a major nonpoint source of downstream salinity.

El-Ashry, M.T. (1980). "Ground-water salinity problems related to irrigation in the Colorado River basin." Ground Water 18(1): 37-45.

The groundwater system in many of the irrigated areas of the Colorado River Basin is derived almost entirely from deep percolation of irrigation water and seepage from irrigation conveyance and tailwater collection systems. Salt pickup rates from irrigated soils in the basin vary in the different areas. Among the high salt pickup areas is the Grand Valley in western Colorado, estimated at 8 tons/acre/year. Water entering the groundwater supply from irrigation practices in the valley amounts to about 145,000 acre-feet/year and contributes about 690,000 tons/year to the salt load of the Colorado River. Samples of base-flow water from the weathered Mancos Shale aquifer in the valley vary in salinity from about 1,500 to about $9,000 \mathrm{mg} / \mathrm{l}$ with a mean of $4,100 \mathrm{mg} / \mathrm{l}$; while water samples from alluvial aquifers range from 305 to $124,000 \mathrm{mg} / \mathrm{l}$ with a mean of about $11,500 \mathrm{mg} / \mathrm{l}$. Base-flow returning to the river in the drains and washes has concentrations that average about $4,200 \mathrm{mg} / \mathrm{l}$. Water losses and quantities of irrigation return flows can be reduced by improving farm irrigation efficiencies and by partial or complete lining of canals, laterals, and ditches. Increasing on-farm irrigation efficiency through system improvements and irrigation scheduling is the most cost-effective measure. However, achievement of higher efficiencies will require changes in water laws to encourage conservation and revised water pricing policies that discourage waste.

Evangelou, V.P. (1981). "Chemical and mineralogical composition and behavior of the Mancos Shale as a diffuse source of salts in the upper Colorado River basin." Available from the National Technical Information Service, Springfield VA 22161 as PB81-197626, March 26 Tab. (Water Resources Center Project UCALWRC-W-562). OWRT-B-201-CAL(1).

Previous investigations relative to salinity in the upper Colorado River Basin have mostly dealt with the total quantities of dissolved solids moving into the Colorado River. Soluble components resulting from dissolution of mineral species have been studied as separate physical entities in the Colorado River, in tributaries of the river and in the Mancos Shale formation. Thus, the Mancos shale itself has been treated basically as an inert material without consideration of possible interactions between soluble and insoluble phases. The purpose of this investigation is to conduct a thorough study of mineralogical and chemical characteristics of Mancos Shale within the West Salt Creek watershed, Colorado. The investigation focuses on the Mancos Shale as a source of soluble components contributing to salinity of the Colorado River including interactive relationships between the more soluble and less soluble mineral phases. The overall investigation has revealed the primary source of salts. Salts are derived from carbonates, calcite and dolomite, which upon contact with sulfuric acid (produced by the biological oxidation of pyrite), produce gypsum and magnesium sulfates. A second source is gypsum as a product of the marine environment left after evaporation had occurred. A third source is the continuous release of ions 
from such sources as dolomite, feldspars and micas. Finally, a fourth source is the leaching of ions of sodium and magnesium coming off the exchange complex of the unweathered Mancos Shale formation.

Evangelou, V.P., L.D. Whittig, and K.K.Tanji (1984). "Dissolved mineral salts derived from Mancos Shale." Journal of Environmental Quality 13(1): 146-150.

The Mancos Shale, a sedimentary Upper Cretaceous marine formation exposed over extensive areas in the Upper Colorado River Basin, is recognized as a major contributor to the dissolved mineral salt load in the Colorado River system. It contains gypsum and alkaline earth carbonates, and its clay mineralogy is mica, kaolin, smectite, and interstratified mica-vermiculite. Selected surface samples of partially weathered Mancos shale were also found to contain from 281 to $345 \mathrm{~g} / \mathrm{kg}$ clay ( $\leq 2 \mu \mathrm{m}$ diameter) and to exhibit cation exchange capacities (CEC) ranging from 13.25 to $19.96 \mathrm{cmol} / \mathrm{kg}$. Water suspension extracts from partially weathered shale (1:5 and $1: 10$ shale: water) were saturated with respect to gypsum (electrical conductivity $(E C)$ values up to $3.16 \mathrm{dS} / \mathrm{m}$ and soluble $\mathrm{Ca}$ and SO4 up to 25.90 and $40.95 \mathrm{mmol} / \mathrm{L}$ respectively. Additional $\mathrm{Na}, \mathrm{K}$, and $\mathrm{Mg}$ released by water indicated sources of soluble ions other than gypsum. Water extracts from unweathered shale yielded much higher quantities of $\mathrm{Na}$ (and higher $\mathrm{Mg}$ in most cases) than did comparable extracts from partially weathered shale. Barium chloride released larger quantities of $\mathrm{Mg}$ from both partially weathered and unweathered shale and large quantities of $\mathrm{Na}$ from unweathered shale than did water at comparable dilutions. The data substantiate the important role of the cation exchange complex in retention and release of soluble ions in Mancos Shale. Sodium and magnesium were preferentially adsorbed by phyllosilicates within the shale and $\mathrm{Ca}$ was precipitated as calcite and gypsum following emergence after deposition in the Cretaceous sea. This cycle is essentially reversed in the present environment. Dispersed gypsum and alkaline earth carbonates provide soluble $\mathrm{Ca}$ to displace adsorbed $\mathrm{Na}$ and $\mathrm{Mg}$ that add to the dissolved mineral salt load of the Colorado River system.

Evangelou, V.P., L.D. Whittig, and K.K. Tanji (1985). "Dissolution and desorption rates of calcium and magnesium from Mancos Shale." Soil Science 139(1): 5361.

The magnitude and rates of dissolution of $\mathrm{Ca}$ and $\mathrm{Mg}$ from alkaline earth carbonates and of desorption of $\mathrm{Ca}$ and $\mathrm{Mg}$ from the cation exchange complex of Mancos shale were studied. Samples of surficial, partially weathered Mancos shale were selectively preconditioned prior to leaching. Selective preconditioning treatments included removal of readily soluble ions, removal of calcite, and exchange saturation with $\mathrm{Na}, \mathrm{Ca}$ and $\mathrm{Mg}$, respectively. Preconditioned samples were leached by a continuous, constant-rate, flow-through system and $\mathrm{Ca}$ and $\mathrm{Mg}$ were measured in incremental leachates. The rates of release of $\mathrm{Ca}$ and $\mathrm{Mg}$ indicate that both emanate from more than 1 source. Selective removal of calcite resulted in an increase in $\mathrm{Mg}$ release to a rate approximately 2.7 times higher than when calcite was present. The rate of release of $\mathrm{Ca}$ from $\mathrm{Ca}$-saturated shale was remarkably constant over the 8 -h leaching period. Only a slight deviation from linearity was observed for release of $\mathrm{Mg}$ from $\mathrm{Mg}$-saturated shale. Rates of release of $\mathrm{Mg}$ from Ca-saturated shale and of $\mathrm{Ca}$ from $\mathrm{Mg}$-saturated shale both increased noticeably with leaching duration. These data demonstrate a significant influence on ion release rates by the cation exchange complex and 
interactive relationships between the exchange complex and alkaline earth carbonates in the system.

Glas, T.K., A. Klute, D. B. McWhorter and L. M. Walsh (1979 (PDF)). "Dissolution and transport of gypsum in soils; II, Experimental." Proceedings of the 43rd annual meeting. Soil Science Society of America, Fort Collins, CO. United States, Aug. 5-10, 1979; Soil Science Society of America Journal 43(2): 268-273.

Experimental information on the dissolution of gypsum and the subsequent transport of the dissolved species in a soilwater system was obtained by adding distilled water to the top of $30-\mathrm{cm}$ long columns containing a soil-gypsum mixture and by measuring the calcium concentration in the solution phase as a function of time at different positions in the columns. The measured concentration-time curves are compared with results from two models - the first based on equilibrium chemical principles and the mixing-cell concept, and the second based on a combination of the one-dimensional convection dispersion equation and a firstorder kinetic expression describing the dissolution process. Under the specific experimental conditions studied, the dissolution process appeared to be kinetically controlled and could not be described by the solubility-product relationship.

Gurdak, J.J., A.l. Greve, and N.E. Spahr (2002 (PDF)). "Water-quality data analysis of the upper Gunnison River watershed, Colorado, 1989-99." U.S. Geological Survey Water-Resources Investigations Report 02-4001.

Water-quality data from October 1969 to December 1999 for both surface water and ground water in the upper Gunnison River watershed were retrieved and compiled from the U.S. Geological Survey National Water Information System and the U.S. Environmental Protection Agency Storage and Retrieval databases. Analyses focused primarily on a subset of these data from October 1989 to December 1999. The upper Gunnison River watershed is located west of the continental divide in the Southern Rocky Mountains physiographic province. Surface-water-quality data were compiled for 482 sites in the upper Gunnison River watershed. Most values of surface-water temperature, dissolved oxygen, and $\mathrm{pH}$ were within Colorado Department of Public Health and Environment (CDPHE) in-stream standards. Calcium bicarbonate type water was the most spatially dominant water type in the basin. Nutrients were most commonly sampled along the Slate River and East River near Crested Butte and along the Gunnison River from the confluence of the East and Taylor Rivers to the western edge of the watershed. Median ammonia concentrations were low, with many concentrations less than laboratory reporting levels. All nitrate concentrations met the CDPHE in-stream standard of 10 milligrams per liter. More than 30 percent of stream sites with total phosphorus data (23 of 61 sites) had concentrations greater than the U.S. Environmental Protection Agency (USEPA) recommendation for controlling eutrophication. Ammonia concentrations at a site on the Slate River near Crested Butte had a statistically significant upward trend for the 1995-99 period. The Slate River near Crested Butte site is located immediately downstream from the towns of Crested Butte and Mount Crested Butte and may reflect recent population growth or other land-use changes. However, the rate of change of the trend is small $(0.017$ milligram per liter per year). Although a multiple comparison test showed nitrate concentrations were statistically different between agriculture and forest sites and between agriculture 
and urban land-use classified sites, median concentrations were low among all land-use settings. Median concentrations of total phosphorus were greatest in rangeland areas and least in urban areas. No significant differences were identified for median concentrations of total phosphorus in agriculture and forest land-use areas. Median concentrations of arsenic, lead, mercury, selenium, and silver were low or below reporting levels throughout the watershed. Aluminum, cadmium, copper, lead, manganese, and zinc concentrations were elevated near the town of Crested Butte and on Henson Creek upstream from Lake City, which may be explained by upstream areas of historical mining. Samples for six trace elements exceeded standards: cadmium, copper, lead, manganese, silver, and zinc. A downward trend ( 3 micrograms per liter per year) was identified for the dissolved iron concentration at a site on the Gunnison River at County Road 32 downstream from the city of Gunnison. Streambed-sediment samples from areas affected by historical mining also had elevated concentrations of some trace elements. Chlorophyll-a concentrations in samples from Blue Mesa Reservoir and streams in the Crested Butte and Gunnison areas were typical of unenriched to moderately enriched conditions. Median concentrations of 5-day biochemical oxygen demand concentrations for sites between Crested Butte and Blue Mesa Reservoir were less than 2 milligrams per liter. Occasional high (greater than 200 counts per 100 milliliters).

Hamilton, S.J., K.M. Holley, K.J. Buhl, F.A. Bullard, L.K. Weston, S.F. McDonald (2004). "Evaluation of flushing of a high-selenium backwater channel in the Colorado River." Envionmental Toxicology 19(1): 51-81.

Concern has been raised that selenium contamination may be adversely affecting endangered fish in the upper Colorado River basin. The objective of the study was to determine if operation of a water control structure (opened in December 1996) that allowed the Colorado River to flow through a channel area at Walter Walker State Wildlife Area (WWSWA) would reduce selenium and other inorganic elements in water, sediment, aquatic invertebrates, and forage fish. Endangered Colorado pikeminnow were collected and muscle plug samples taken for selenium analysis. Selenium concentrations in filtered water were 21.0 $\mathrm{g} / \mathrm{L}$ in $1995,23.5 \mathrm{~g} / \mathrm{L}$ in $1996,2.1 \mathrm{~g} / \mathrm{L}$ in 1997 , and $2.1 \mathrm{~g} / \mathrm{L}$ in 1998 . Selenium concentrations in sediment cores and sediment traps were $8.5 \mathrm{~g} / \mathrm{g}$ in $1995,8.2$ $\mathrm{g} / \mathrm{g}$ in $1996,4.8 \mathrm{~g} / \mathrm{g}$ in 1997 , and $1.1 \mathrm{~g} / \mathrm{g}$ in 1998 . Selenium concentrations in aquatic invertebrates were $27.4 \mathrm{~g} / \mathrm{g}$ in $1996,15.5 \mathrm{~g} / \mathrm{g}$ in 1997 , and $4.9 \mathrm{~g} / \mathrm{g}$ in 1998. Selenium concentrations in forage fish were $27.2 \mathrm{~g} / \mathrm{g}$ in $1996,20.2 \mathrm{~g} / \mathrm{g}$ in 1997 , and $8.6 \mathrm{~g} / \mathrm{g}$ in 1998 . Selenium concentrations in muscle plugs of Colorado pikeminnow were $9.8 \mathrm{~g} / \mathrm{g}$ in $1995,9.5 \mathrm{~g} / \mathrm{g}$ in $1996,9.0 \mathrm{~g} / \mathrm{g}$ in 1997 , and $10.3 \mathrm{~g} / \mathrm{g}$ in 1998. Although selenium concentrations in water, sediment, aquatic invertebrates, and forage fish decreased substantially after operation of the water control structure, a corresponding change in Colorado pikeminnow did not seem to occur. Selenium concentrations in muscle plugs decreased with increasing fish total length and weight, did not change between repeat sampling in the same year or recapture in subsequent years, and seemed to be most closely associated with the mean monthly river flow for the March-July period.

Jackson, W., and R.P. Julander (1982). "Runoff and water quality from three soil landform units on Mancos Shale." Water Resources Bulletin Vol 18, No 6, p 9951001, December, 1982. 7 Fig, 4 Tab. 10 Ref. 
Simulated rainfall was applied to three landforms underlain by Mancos shale in the Price River Basin, Utah, to determine the relative yields of water, sediment, and salt from this saline sedimentary formation. The three types of soil were: (1) soil A-shale pediment/recent alluvium, (2) soil D-shale pediment/recent alluvium, and (3) soil A and weathered shale dissected Mancos shale uplands. Final infiltration rates on residual shale derived soils were $0.13-0.50 \mathrm{~cm}$ per hour. No runoff was generated on cracked soils derived from eolian deposits. A steep dissected Mancos shale upland produced 180 times the suspended sediment concentrations and 68 times the EC (indicating salinity) compared to a low relief shale pediment and recent alluvial surface. Rilling was responsible for $80 \%$ of the sediment produced on the steep dissected shales. Channel scour and soil creep were also significant contributors to sediment. An estimated 1.35 million g per ha per year of sediment is produced by the steep dissected shale uplands. Sediment plugs were effective in trapping sediments on a local basis to improve quality of water for stock ponds and irrigation canals.

Johnson, R.K., and S.A. Schumm (1982). "Geomorphic and lithologic controls of diffuse-source salinity, Grand Valley, western Colorado." Available from the National Technical Information Service, Springfield VA 22161 as PB82-256587. April 1 Append. OWRT B-203-COLO(1). 14-34-0001-0210.

Grand Valley Mancos Shale, composed of a thick sequence of interbedded shale and sandstone, is a significant contributor of dissolved solids to the upper Colorado River. Research was carried out to describe the area geomorphology and soluble mineral content relationships of surficial materials in erosionallyunstable landforms, to relate geomorphic stability to salt release processes from the area, and to recommend land use and/or salt control measures for reducing salt load alluvial valley floors, and badlands, with the latter having the greatest surface area. The badlands are the least stable landform, releasing more sediment and salt into runoff than the other landforms. Pediments are capped by cemented gravels and are the most stable landform, while the alluvial valley floors are generally also stable to sediment/salt production. Recommendations for understanding erosional and salinity characteristics of runoff from the badlands and for reducing erosion/salinity related to current land use include examining the effectiveness of existing sediment retention structures, comparing sediment load and salinity of runoff from two drainage basin lithologies, and reducing gully erosion caused by road drainage ditches/culverts.

Jurinak, J.J., J.C. Whitmore, and R.J. Wagenet (1977 (PDF)). "Kinetics of salt release from a saline soil." Science Society of America Journal 41(4): 721-724.

The kinetics of salt release from simulated saline sediments was studied to ascertain the potential of sediments as a diffuse source of salinity. Two rate equations were derived, both based on the premise that dissolution is a diffusion controlled process. The equations were $1 n(1-C / C$ sub $s)=-k t$ and $C=k$ ' $t(1 / 2)$, where $\mathrm{c}$ is the concentration at any point in the bulk solution, $\mathrm{c}$ sub $\mathrm{s}$ is the equilibrium concentration of the soluble soil minerals, $t$ is time, $k$ is the first-order rate constant, and $\mathrm{k}$ ' a proportionality constant. Kinetic data were obtained from a saline typic torriorthent soil derived from Mancos shale in the Price River Basin, Utah. During the initial 72 hours of reaction, dissolution can be described by three diffusion controlled reactions. Increasing particle size decreased the rate of reaction. Both derived equations were equally effective in describing salt release. 
Korte, N.E. (2000 (PDF)). "Selenium poisoning of wildlife and western agriculture: cause and effect." U.S. Department of Energy Office of Science Budget Activity Number 264200000.

This project examined the hypothesis that selenium contamination is not the principal cause of the decline of endemic fish species in the Upper Colorado Basin. Activities employed to test this hypothesis included a reconnaissance of locations altered by recent road construction, a reinterpretation of available literature regarding selenium toxicity, and the interpretation of unpublished data obtained from the Upper Colorado Basin Fish Recovery Program. The project demonstrates that most of the evidence implicating selenium is circumstantial. Specifically, this research demonstrates that neither the historical record nor the technical literature consistently supports the emphasis given selenium toxicity. For example, many locations in the intermountain region have elevated selenium in water and sediments without obvious consequences for wildlife. Consequently, biological and geochemical studies are required to understand the cycling, relative abundance, and bioavailability of selenium and other constituents so that causal agents in the Upper Colorado Basin can be identified with greater certainty. The project also demonstrates the need for subcellular indicators of selenium poisoning. Unfortunately, most potential biomarkers are not specific for selenium. A potential candidate based on the mammalian literature is glutathione peroxidase (GPx) activity and/or the cellular levels of reduced glutathione and hydrogen selenide (Greeley, M.S., Oak Ridge National Laboratory, personal communication, Jan. 22, 1999). Evidence of increased lipid peroxidation and related glutathione peroxidase activity has been found in aquatic birds at sites such as Kesterson (Hoffman and Heinz 1988; Ohlendorf et al. 1988). Selenium has an antimutagenic effect so genomic research is not feasible. However, the activity of the GPx gene could be explored as a potential selenium biomarker. Little is known regarding the mechanistic relationships between GPx and selenium, which of itself is an area where additional research would provide important information. Studies also are needed with the endangered fish and other species to develop predictive tools regarding the manner in which selenium cycles geochemically and biologically in riverine and backwater environments. Finally, hydrological investigations and modeling are needed to further examine the coordination of dam operation and water diversions to determine whether modifications can provide the habitat necessary to ensure survival of the endangered species. The performance of this project has developed the relationships and knowledge required to advance proposals in the specific areas just described. Within the Environmental Sciences Division (ESD), a seminar and several group discussions were held to identify team members for proposals. Potential funding sources within and outside of the U.S. Department of Energy (DOE) have been identified, and ESD staff members are approaching these informally. The preparation of one or two proposals is anticipated during FY 2000. Finally, the journals Bioscience and Reviews in Fisheries Science were selected as appropriate venues for publishing this work, and a manuscript is in preparation.

Laronne, J.B. and S.A. Schumm (1977). "Dissolution potential of surficial Mancos Shale and alluvium." Available from the National Technical Information Service, Springfield VA 22161 as PB-291 464, Price codes: A07 in paper copy, A01 in 
microfiche. PhD Dissertation, 1977. 128 p, 21 fig, 13 tab, 53 ref, append. OWRT B-121-COLO(1), 14-31-0001-5061.

The objectives were to determine the salt content of Mancos Shale and associated alluvium and the release mechanisms of salt from these deposits. When mixed with distilled water, the time necessary to approach equilibrium decreased with an increase of salt content and with a decrease of sediment concentration, and the time span required for equilibrium ranged from a few minutes to several days. The chemical quality of the aqueous mixtures was of the $\mathrm{Ca} 2+-M G 2+-\mathrm{Na} 1+-\mathrm{SO} 42--\mathrm{HCO} 31$ - type. Sodium and magnesium hydrated sulfates appeared to dissolve faster than gypsum or calcite and the relative abundance of $\mathrm{Na} 1+, \mathrm{Mg} 2+$ and SO42- decreased with increased dilution. There is a large inherent variability in the salt content of sampled sediments. Soluble mineral content of Mancos Shale from hillslopes (2 percent) is significantly larger than that of terrace alluvium (0.62-0.29 percent) and bed materials $(0.93-0.81$ percent) of North Miller and West Salt Creeks respectively. The most saline deposits (10 percent) are efflorescent bed crusts. Terrace and bed materials in narrow valleys where shallow alluvium overlies shale are highly saline (1.6 percent) and show an increase in salt content with depth. The results also show that major areas of diffuse sources of salts are also the major sediment contributors in the Upper Colorado River Basin.

Laronne, J.B., and S.A. Schumm (1982). "Soluble mineral content in surficial alluvium and associated Mancos Shale." Water Resources Bulletin 18(1): 27-35.

Most arid and semiarid regions experience problems resulting from high salt content in soils and from high solute concentrations in runoff. The rate of salt pickup under varying hydrologic conditions depends on net dissolution and sediment removal rates and on soluble mineral content and its spatial and temporal variations. The Mancos Shale terrain is a source of considerable solute contribution to the Colorado River. The spatial variability of soluble mineral content in weathered Mancos Shale and its associated alluvium was studied in an effort to understand the mechanism of salt production and to determine the source of salinity. Soluble mineral content was found to be highly variable in the alluvium and in associated surficial Mancos Shale. However, it was possible to identify lithomorphological units based on the soluble mineral content. Study results show that crusts are leached in deep alluvial fills, and that they have somewhat lower soluble mineral contents than underlying Mancos Shale on hillslopes. The crusts were found to be saline, sometimes efflorescent, in shale bedrock channels or where channels abut against the shale. Soluble mineral content increases in alluvium with decrease in depth of alluvial fill, does not vary significantly with depth in deep alluvial fills, and increases with depth in shallow fills. Soluble mineral content trends identified by this study can be used in the development of mathematical models and land management programs in areas of the Colorado River basin experiencing salinity problems.

Laronne, J.B., and H.W. Shen (1982). "The effect of erosion on solute pickup from Mancos Shale hillslopes, Colorado, USA." Journal of Hydrology 59.

Sediment concentration has been shown to be statistically related to solute concentration. A causal relationship is demonstrated between these water quality variables. Solute concentration, which for a constant discharge is linearly related to solute production, increases with increases in sediment yield during rilling and 
rill entrenchment due to dissolution of transported sediment particles. Moreover, solute release increased as the power per unit width of surface area increased, thereby causally explaining the high correlation between runoff salinity and slope inclination. The regression between these two variables may be used as a tool to assess salinity hazard. The proportions of solute yield derived entirely from contact with the soil surface or from dissolution of transported sediment have not been determined. It is assumed that a significantly larger proportion of solute yield from Mancos Shale hillslopes originates from transported sediment than that demonstrated herein. Direct runoff rather than rainfall induced runoff was generated on the studied hillslopes.

Lemly, A.D. (1997). "Environmental hazard of selenium in the Animas La Plata water development project." Ecotoxicology and Environmental Safety 37(1): 9296.

A hazard assessment of selenium was conducted for the Animas La Plata Project, a multiple-use water development proposed for Colorado and New Mexico by the United States Bureau of Reclamation. A published protocol for aquatic hazard assessment of selenium was applied to environmental monitoring data to assess current threats to biota in the water supply rivers (Animas, La Plata, and Mancos Rivers). Hazard evaluations were also made for two proposed reservoirs (Ridges Basin and Southern Ute Reservoirs) based on estimated concentrations of selenium. The assessment protocol indicated moderate hazard in the Animas and La Plata Rivers, and high hazard in the Mancos River and both of the proposed reservoirs. These ratings indicate that the risk of selenium poisoning in fish and aquatic birds is substantial. Moreover, the geology and climate of this site make it prone to irrigation-induced selenium contamination of water and biota. The water supplies already contain dangerously high concentrations of selenium that may increase further due to agricultural irrigation drainage. The stage is set for significant environmental problems unless a development scenario can be devised that will effectively reduce ecological risks.

Lin, A. (1983). "Study of salinity production from wildlands of Price River Basin, Utah." Salinity in Watercourses and Reservoirs. Proceedings of the 1983 International Symposium on State-of-the-art control of salinity, July 13-15, 1983 , Boston.

The importance of hillslope erosion in sediment and salinity production of the Price River Basin, Utah is confirmed. In investigating hillslope erosion processes, it is necessary to consider (1) the difference between the ' first event ' and the others in a running sequence, and (2) the separation of mass wasting, if it exists, from overland flow processes. The Universal Soil Loss Equation (USLE) could be useful in western wildland if the coverage factor is properly calibrated. Additionally, to use USLE effectively for individual events should be applied to runoff source areas. In-channel solute pick-up could be important where Mancos Shale is exposed. For a fixed amount of exposure of Mancos Shale in a watershed, there should be an upper limit for the salt encrustation along the exposed part. It is postulated that given sufficient time for salt crust to mature, the amount of in-channel solute pick-up for a 'first event ' is more or less a fixed quantity. Thunderstorms in the summer and fall produce an estimated $11 \%$ of total salt load in the basin. There is no data to assess salt production generated from erosion associated with spring snowmelt runoff. 
Lin, A., W.L. Jackson, and K.D. Knoop (1984). "Storm runoff and water quality on three ephemeral washes in the Price River Basin, Utah." Journal of Soil and Water Conservation Vol.39, May-June 16 Ref. Bureau of Land Management Contract YA553-CT1-1064

Eighteen late summer runoff events were monitored in 1981 on three small watersheds in the Price River Basin, Utah. Surface runoff contributes significant quantities of sediment and salt to the Colorado River system. Total dissolved solids/total solids ratios and the correlation between average storm total dissolved solids and surface soil loss potential, as indexed by the Universal Soil Loss Equation parameters supports the hypothesis that surface erosion of Mancos Shale hillslopes is an important salt-contributing process. Watershed activities, such as vegetation management, contour furrows, or small retention structures that reduce erosion of highly erosive Mancos Shale hillslopes and channels or that retain runoff on these sites, can help reduce salinity in the Colorado River. Less actively eroding shale features are more likely to be leached of soluble salts at the soil surface and are less important sources of salinity in surface runoff. Salinity in these areas would be less manageable through surface runoff and erosion control practices.

Montague, K. (2004 (PDF)). "Price River, San Rafael River, and Muddy Creek TMDLs for total dissolved solids Eastern Utah watershed management unit, Utah." Utah Division of Water Quality.

This TMDL study has been prepared for the Price River, San Rafael River, and Muddy Creek watersheds. These three watersheds encompass a large portion of the Eastern Utah Watershed Management Unit located in east-central Utah. Water quality assessments completed by the Utah Department of Environmental Quality, Division of Water Quality (DEQ) in 1997, resulted in several stream segments in these watersheds being listed on the Utah's 303 (d) list for impaired waters in 2000 . The DEQ determined that primarily due to high concentrations of total dissolved solids (TDS) several portions and/or tributaries of the Price River its headwaters and the Green River are non-supporting or partially supporting of their agricultural use classifications. Additionally, for certain smaller river sections, $\mathrm{pH}$, dissolved oxygen (DO), and dissolved iron ( $\mathrm{Fe}$ ) are also cited as causing impairment. The water quality assessment performed by the $D E Q$, which was also supported by water quality sampling performed by the Emery County Water Conservancy District (EWCD), also revealed that agricultural use classifications are not being supported in several stream segments in the San Rafael and Muddy Creek watersheds as a result of high concentrations of TDS in these waters. The impaired stream segments in the watershed are listed in Table $1-1$. Section 303 (d) of the Clean Water Act requires states to identify water bodies not currently meeting water quality standards after technology-based controls are in place. Consequently, states are required to have TMDLs established in order to attain water quality standards for impaired waters. The TMDL establishes allowable loadings for pollutants for a given water body. Although $\mathrm{pH}$, dissolved oxygen (DO), and iron ( $\mathrm{Fe}$ ) have also been cited as causing water quality impairments in the Price River and one tributary (see Table 1-1), the focus of this TMDL study is TDS. As described in Section 3.1 of this report, analyses of available data indicate that there are no impairments attributable to $\mathrm{DO}$ and $\mathrm{pH}$ (Toole 2003). This section of the report describes the purposes of this TMDL study, the watersheds studied, and the associated water 
quality impairments. Section 2 of this report describes the applicable water quality standards and the establishment of target sites and a TMDL endpoint. Section 3 discusses the assessment of the current water quality in the watersheds and impairment analysis. Section 4 addresses the sources of TDS loading in the watersheds. Section 5 describes the methods that were used to establish TDS loading capacity, and Section 6 describes the TMDL allocations required to meet established TMDL endpoints.

Osmundson, B.C., T.W. May, and D. B. Osmundson (2000 (PDF)). "Selenium concentrations in the Colorado Pike minnow (Ptychocheilus lucius): relationship with flows in the Upper Colorado River." Archives of Environmental Contamination and Toxicology 38(4): 479-485.

A Department of the Interior (DOI) irrigation drain water study of the Uncompahgre Project area and the Grand Valley in western Colorado revealed high selenium concentrations in water, sediment, and biota samples. The lower Gunnison River and the Colorado River in the study area are designated critical habitat for the endangered Colorado pikeminnow (Ptychocheilus lucius) and razorback sucker (Xyrauchen texanus). Because of the endangered status of these fish, sacrificing individuals for tissue residue analysis has been avoided; consequently, little information existed regarding selenium tissue residues. In 1994, muscle plugs were collected from a total of 39 Colorado pikeminnow captured at various Colorado River sites in the Grand Valley for selenium residue analysis. The muscle plugs collected from 16 Colorado pikeminnow captured at Walter Walker State Wildlife Area (WWSWA) contained a mean selenium concentration of $17 \mathrm{7g} / \mathrm{g}$ dry weight, which was over twice the recommended toxic threshold guideline concentration of $87 \mathrm{~g} / \mathrm{g}$ dry weight in muscle tissue for freshwater fish. Because of elevated selenium concentrations in muscle plugs in 1994 , a total of 52 muscle plugs were taken during 1995 from Colorado pikeminnow staging at WWSWA. Eleven of these plugs were from fish previously sampled in 1994. Selenium concentrations in 9 of the 11 recaptured fish were significantly lower in 1995 than in 1994. Reduced selenium in fish may in part be attributed to higher instream flows in 1995 and lower water selenium concentrations in the Colorado River in the Grand Valley. In 1996, muscle plugs were taken from 35 Colorado squawfish captured at WWSWA, and no difference in mean selenium concentrations were detected from those sampled in 1995. Colorado River flows during 1996 were intermediate to those measured in 1994 and 1995.

Peterson, S.R., J.J. Jurinak, and R.J. Wagenet (1980). "Salt release from suspended sediments: A simulation model." Available from the National Technical Information Service, Springfield VA 22161 as PB81-231839, December 14-34-0001-9047.

The effects of particles size, soil to water ratio and time on the rate of release of salts from Mancos Shale derived soils were studied by taking four different size fraction at three different dilutions of soil to water. The kinetic model was formulated using data obtained from a soil dominated by highly soluble salts (evaporites) and using dimensional analysis. The chemical equilibrium model developed in this project was based on ion association theory, with equilibrium constants chosen as the data base. The requisite chemical equations programmed were solved by iterative techniques (successive approximations). 
The chemical model was interfaced with the kinetic model, thus all input data necessary for the chemical model were produced by the kinetic model; these input data were the total concentrations of individual ions. The equilibrium model accepted these input data and calculated the concentrations, activities, and activity coefficients for all ions and their soluble complexes. The model also predicted which salts were dissolving and by determining the saturation indices how quickly individual mineral salts approached equilibrium.

Pliler, R. and J. A. S. Adams (1962). "The distribution of thorium, uranium, and potassium in the Mancos Shale." Geochimica et Cosmochimica Acta 26: 11151135.

Over 135 samples of the upper Cretaceous Mancos Shale have been analyzed for $U, T h$, and $K$ by chemical and radiometric means. These samples were collected from 16 localities in Colorado, Utah, Arizona, and New Mexico. The average concentrations in the Mancos Shale samples are $10.2 \mathrm{ppm}$ Th, $3.7 \mathrm{ppm}$ $\mathrm{U}$, and $1.9 \% \mathrm{~K}$ as metal. The average $\mathrm{Th} / \mathrm{U}$ ratio is 3.1 . For the most part, the variations in the Th, $\mathrm{U}$, and $\mathrm{K}$ concentrations are gradual and take place over large distances. Th, Th/ $U$ ratio, and $K$ tend to decrease and $U$ tends to increase with distance from the Upper Cretaceous shoreline. The K/Th ratio in the shale, including sandy intertongues, shows remarkably little variation on a regional basis. Laboratory studies indicate that the $U$ in the Mancos Shale is present largely in the fine-grained primary resistate minerals, and the Th occurs in the fine-grained secondary resistates or fixed in or on clays.

Ponce, S.L., R.H. Hawkins, J.J. Jurinak, G.F. Gifford, and J.R. Riley (1975). "Surface runoff and its effect on diffuse salt production from Mancos Shale members." Watershed Management Watershed Management, Proceedings, Irrigation and Drainage Division American Society of Civil Engineers, August 1113, 1975, Logan, Utah.

A study was done within the Price River Basin, one of the major sources of salinity to the Colorado River, located in East-Central Utah. Results indicated that alluvial deposits very near the channel of a perennial stream tend to yield runoff water of high salinity. The Blue Gate and Mancos undivided Shale members are the prime salt producers in the Basin. No simple relation was found between soil salinity and salinity of the runoff water over the soil. A slight correlation was noted between geologic type and the ratio of surface runoff to precipitation, while hydrologic soil-complex numbers showed no distinct separation between types. Strong linear relations exist between electrical conductivity and $\mathrm{Ca}(++)$ and $\mathrm{SO}_{4}$ (-) while poor correlations exist between the ratio of surface runoff to precipitation and surface runoff to total solids for runoff from the Mancos members.

Riley, J. P., D. G. Chadwick, Jr., L. S. Dixon, L. D. James, W. J. Grenney and E. K. Israelsen (1982 (PDF)). "Salt uptake in natural channels traversing Mancos shales in the Price River basin, Utah." Utah Water Research Laboratory. Utah State University.

Field and laboratory measurements of process rates for runoff and salt movement were used to develop and calibrate a hydrosalinity model of outflows from the Price River Basin at Woodside, Utah. The field measurements were specifically used to formulate a model for estimating surface flow (both overland 
and from small ephemeral channels) in the Coal Creek Basin on the valley floor of the Price River Basin. The basin simulation assessment model (BSAM) was used to combine local flows and model total outflow from the Price River. The results must be regarded as a first generation model that, while giving ostensibly reasonable results, needs much additional refinement and validation by collecting additional field data. As to field data, observed salt loading rates reached 518 pounds per square mile daily, groundwater inflow declined steadily throughout the summer but maintained constant salt concentrations, channel efflorescence varied more than 100 fold with the largest concentrations occurring in saturated bed material, and turbulent mixing and cyclic drying added to salt dissolution rates. Extrapolation of the results with the Coal Creek model showed only a very small percentage of the salt loading from the valley floor to originate from natural lands. BSAM showed average annual salt leaving the Basin at Woodside to be 190,000 tons, 114,000 tons coming from the mountain area and 76,000 from the valley floor. Of the valley floor contribution, only 3,500 tons are produced by surface runoff from nonirrigated areas. Topics to be emphasized in further model development include salt contribution from percolation snowmelt on natural lands, ground-water movement, the formation and dissolution of efflorescence, and salt-sediment transport by the sharp hydrographs on small ephemeral streams.

Rao, B.K., D.S. Bowles, and R.J. Wagenet (1984). "Salt efflorescence in Price River Basin." Journal of Environmental Engineering 110: 457-471.

Salt efflorescence has been hypothesized to be an important nonpoint source of salinity in the Price River basin which is a major salt contributor, relative to its contribution of water, to the Colorado River system. Efflorescent salt loading was investigated through field studies, aerial photography, laboratory experiments, and mathematical modeling. The conditions favorable to the formation of salt efflorescence crusts are highly saline soil water near the soil surface and a source of heat above the soil for evaporating the soil water. Field data indicate that the salt efflorescence crust forms over the first 10-15 days after a storm runoff washes off the earlier efflorescence. After this period, the efflorescence crust apparently acts as a physical barrier to further soil water evaporation. Observation from aerial photography suggest that the major source of salt for efflorescence is the water that infiltrates saline geological formations and returns to ephemeral streams with dissolved salts. An expected value of salt efflorescence crust density at the time of a storm was computed by fitting an exponential probability distribution for the time interval between consecutive summer storms in the Price River basin. This density, which was estimated as $1.40 \mathrm{~kg} / \mathrm{sq} \mathrm{m}$, was used with an average number of four storms per year and the fraction of the total basin area underlain by marine Mancos shale to obtain the estimate that salt efflorescence contributes approximately $8.5 \%$ of the total salt loading in the Price River basin. It was assumed that all the salt efflorescence crust is washed off during each storm, and that no salt is leached back into the soil. Therefore, the foregoing percentage may be expected to be an upper bound estimate. Also, it neglects efflorescent salt loading outside the summer season. This study adds to the previous studies in the Price River basin in concluding that the surface salt sources produce a relatively small fraction of the total loading. This conclusion suggests that subsurface sources of salt pickup are significant and future salt loading studies in the basin should consider subsurface processes. 
Shirinian-Orlando, A.A., and C.G. Uchrin (2000). "A method for determining salt sources in surface waters." Journal of the American Water Resources Association 36(4): 749-757.

This paper presents a method for determining the causes of salinization of surface waters, in this case the upper Colorado River and its tributaries. The analysis, which includes a combination of statistical analysis and graphical methods, indicates that among the sources of salt (e.g., saline ground water discharge into surface waters and storm runoff both surface and shallow subsurface, and washing minerals into surface waters) the major contributor is saline ground water, which discharges into the river and streams. Data also points to salt plume intrusion into the river and streams from sources of salt in the aquifers.

Scott, C. and C. Hayden. (1992). Clay mineralogy of the upper Cretaceous Mancos Shale near Mesa Verde National Park, southwestern Colorado; clues to the paleoceanography of the western Interior Seaway. Department of Geology and Geography, University of Massachusetts, Amherst: 225

During Late Cretaceous time, marine shales and mudstones accumulated in the Western Interior Seaway, covering much of the southern Colorado Plateau and adjacent areas. The history of the sea is well preserved in the San Juan Basin, located in the eastern portion of the Colorado Plateau. In a stratigraphic section near Mesa Verde National Park, Colorado, the Mancos Shale records a series of four transgressions and regressions during the Greenhorn and Niobrara Cyclothems (late Cenomanian to early Campanian). These sea level changes were controlled by tectonic and/or eustatic events. X-ray diffraction (XRD), scanning electron microscopy (SEM) and an energy dispersive system (EDS) were used in this extensive study of the clay minerals in the 700 meter stratigraphic section of the Mancos Shale. The relative abundances of kaolinite, illite, chlorite and illite/smectite vary throughout the stratigraphic section, as do other mineralogical characteristics, such as the percent of illite within illite/smectite. SEM analyses suggest that the clay minerals have not undergone recrystallization during burial diagenesis. Additional information, such as percent carbonate, was also incorporated into this study. Changes in clay mineralogy correlate with transgressive and regressive events of the Greenhorn and Niobrara seaways. Because of its large particle size, kaolinite is generally a good near-shoreline position indicator, but an exception to this rule occurred during maximum transgression of the Greenhorn Sea in early Turonian time. The increase in kaolinite abundance during this transgression reflects climatic change in the source area. Illite, because of its small particle size, is also a good shoreline position indicator. Using variations in peak-width at half height, illite can also serve as a source area indicator. Relatively small amounts of chlorite are a source area indicator, because its presence may have been dependent on the position of the Frontier delta in Wyoming and paleocirculation patterns on the western side of the interior seaway. Variable amounts of detrital mixed-layered illite/smectite are present in the Mancos Shale at Mesa Verde, indicating the presence of altered volcanic ash in the source area. The proportion of illite in the illite/smectite also varies throughout the stratigraphic section, further serving as evidence for multiple source areas. 
Spahr, N.E., L.E. Apodaca, J.R. Deacon, J.B. Bails, N.J. Bauch, C.M. Smith, and N.E. Driver (2000 (PDF)). "Water quality in the Upper Colorado River Basin, Colorado, 1996.98." U.S. Geological Survey. Circular 1214.

This report summarizes major findings about water quality in the Upper Colorado River Basin that emerged from an assessment conducted between 1996 and 1998 by the U.S. Geological Survey (USGS) National Water-Quality Assessment (NAWQA) Program. Water quality is discussed in terms of local and regional issues and compared to conditions found in all 36 NAWQA study areas, called Study Units, assessed to date. Findings are also explained in the context of selected national benchmarks, such as those for drinking water quality and the protection of aquatic organisms. The NAWQA Program was not intended to assess the quality of the Nation's drinking water, such as by monitoring water from household taps. Rather, the assessments focus on the quality of the resource itself, thereby complementing many ongoing Federal, State, and local drinking-water monitoring programs. The comparisons made in this report to drinking-water standards and guidelines are only in the context of the available untreated resource. Finally, this report includes information about the status of aquatic communities and the condition of instream habitats as elements of a complete water-quality assessment. Many topics covered in this report reflect the concerns of officials of State and Federal agencies, water-resource managers, and members of stakeholder groups who provided advice and input during the Upper Colorado River Basin assessment. Basin residents who wish to know more about water quality in the areas where they live will find this report informative as well. The NAWQA Program seeks to improve scientific and public understanding of water quality in the Nation's major river basins and groundwater systems. Better understanding facilitates effective resource management, accurate identification of water-quality priorities, and successful development of strategies that protect and restore water quality. Guided by a nationally consistent study design and shaped by ongoing communication with local, State, and Federal agencies, NAWQA assessments support the investigation of local issues and trends while providing a firm foundation for understanding water quality at regional and national scales. The ability to integrate local and national scales of data collection and analysis is a unique feature of the USGS NAWQA Program. The Upper Colorado River Basin is one of 51 water-quality assessments initiated since 1991, when the U.S. Congress appropriated funds for the USGS to begin the NAWQA Program. As indicated on the map, 36 assessments have been completed, and 15 more assessments will conclude in 2001. Collectively, these assessments cover about one-half of the land area of the United States and include water resources that are available to more than 60 percent of the U.S. population.

Stephens, D.W., B. Waddell, A. Peltz, and J.B. Miller (1992). "Detailed study of selenium and selected elements in water, bottom sediment, and biota associated with irrigation drainage in the Middle Green River Basin, Utah 1988-90." Available from Books and Open File Report Section, USGS, Box 25425, Denver, CO 80225. USGS Water-Resources Investigations Report 92-4084, 1992. 164p, 64 fig, 48 tab, 96 ref.

Studies completed at Stewart Lake Waterfowl Management Area, lower Ashley Creek, Ouray National Wildlife Refuge, and Pariette Wetlands, Utah identified several areas where selenium was adversely affecting water quality and creating 
a hazard to wildlife. The source of contamination at Stewart Lake is drainwater and shallow groundwater from soils derived from Mancos Shale. Median concentrations of selenium in all drainwater discharged to Stewart Lake exceeded the State standard of $5 \mathrm{micro} / \mathrm{L}$ established for wildlife protection. Selenium concentrations of all biological tissues sampled at Stewart Lake Waterfowl Management Area were large compared to concentrations in biota from most other sites in the middle Green River basin. Selenium concentrations in Ashley Creek upstream of the City of Vernal generally were less than 1 micro/L but 12 miles downstream averaged $73 \mathrm{micro} / \mathrm{L}$. The source of the contamination was believed to be from inflows of shallow groundwater and surface water originating as seepage from a sewage-lagoon system that flows through Mancos Shale and mobilizes selenium. Waterflow from the area contained selenium concentrations as large as $27.2 \mathrm{micro} / \mathrm{g}$ in muscle tissue, and an eared grebe egg contained 71 micro/g. Selenium contamination of ponds at Ouray National Wildlife Refuge was limited to a small area on the western part of the refuge and was apparently due to seepage of shallow groundwater into waterfowl ponds. Geometric mean concentrations of selenium in plants, invertebrates, bird eggs, and fish from the North and South Roadside Ponds were larger than concentrations known to cause reproductive failure in mallards.

Sunday, G. (1979). "Role of rill development in salt loading from hillslopes." Available from the National Technical Information Service, Springfield VA 22161 as PB80-199540. MS Thesis, Fall, 1979. 117 p, 54 Fig, 13 Tab, 17 Ref, 1 Append. OWRT B-170-COLO(2).

A field study, a computer simulation, and flow velocity experiments were used to identify the major contributing factors in salt loading of the Colorado River from hillslopes above the river. The field study of artificially induced runoff over Mancos shale was conducted on sites with little vegetation located north of the Grand Junction, Colorado, airport and in the West Salt Creek Basin near Mack, Colorado. The longitudinal slopes ranged from 7 to 41 degrees with lengths of from 40 to 225 feet. Two sources of water were used: (1) direct runoff applied from a perforated pipe, and (2) runoff from a rain sprinkler system. Rill formation was recorded with careful field notes and movie films. Results show a welldefined relationship between salinity of runoff and slope for direct runoff. Major factors in salt loading were identified as (1) amount of runoff, (2) suspended sediment concentrations associated with rill flow, (3) degree of slope, (4) salt potential of the soil, and (5) method of introduction of flow. In the study of rill development by computer simulation, a hypothetical drainage area is represented by a square $(100 \times 100)$ matrix, and rill patterns are generated by a series of moves between adjacent points in the matrix. Drainage patterns resulting from the simulation are checked against Horton's laws of drainage composition. In a laboratory control situation, three loading factors were studied: (1) increased flow velocities, (2) different layers of Mancos shale (unweathered and weathered), and (3) particle size of shale. Unweathered shales were found to yield more salt than weathered shales if equally exposed surface area is considered.

Utah Department of Environmental Quality Division of Water Quality TMDL Section (2003 (PDF)). "Ashley Creek Selenium and total dissolved solids TMDL." 
This document addresses water quality impairments within the lower Ashley Creek watershed through the establishment of Total Maximum Daily Loads (TMDLs) for Selenium (Se) and Total Dissolved Solids (TDS). The purpose of this TMDL is to improve water quality and protect or restore designated beneficial uses. Lower Ashley Creek, from the confluence with the Green River upstream approximately 8 miles, is listed on the State's 303D list of impaired waters and has been designated as not meeting its warm water fishery beneficial use (3B) due to high concentrations of Se and its agricultural beneficial use (4) due to high concentrations of TDS. The source of impairment originates primarily from seepage from the Ashley Valley Sewage Lagoons through an outcrop of Mancos shale, a naturally occurring geologic formation that borders the east side of Ashley Creek. Permitted point source discharges in the watershed include the Ashley Valley Water Reclamation Facility, a mechanical waste water treatment plant, and five oil wells in the Ashley Oil Field. The Ashley Creek Watershed is located in the northeast corner of the State of Utah and encompasses 393 square miles. Elevations range from over 9,500 feet in the Uinta Mountains to the north, down to 5,000 feet at the confluence with the Green River. Vegetation types are characteristic of the Rocky Mountains and Colorado Plateau with coniferous forests dominating the high elevations, pinyon-juniper forests at mid elevations and sagebrush-grass and agricultural lands in the valley bottom. Ashley Creek is the primary drainage in the watershed flowing from the Uinta Mountains in the north, through Ashley Valley and into the Green River forty-five miles to the southeast. Flows in Ashley Creek vary widely due to spring snow melt, irrigation diversions, and occasional thunderstorms. During spring runoff stream flows average 195 cubic feet per second (cfs), 24 cfs during irrigation season and 34 cfs during the winter near Jensen above the confluence with the Green River. Approximately 12,000 people reside within the watershed with the majority living in the city of Vernal. The economy of the watershed is based upon tourism, fossil fuel production and agriculture. Recreational opportunities abound on nearby National Forest lands, Dinosaur National Monument and Green River. Because of the natural geologic sources of $\mathrm{Se}$ and TDS that underlie Ashley Valley there will always be some Se and TDS non-point source loading into Ashley Creek. However, several projects currently underway within the watershed will improve the water quality and riparian habitat of Ashley Creek. A locally led watershed planning effort, the Ashley Creek Restoration and Stabilization Committee, is addressing chronic flooding, water quality and riparian habitat issues on Ashley Creek. The Army Corps of Engineers is about to begin implementation on a riparian restoration project on Ashley Creek above the Steinaker diversion, the Ashley Valley Sewer Improvement District has recently constructed a new wastewater treatment plant, and the Uintah County Water Conservancy District, in cooperation with the Bureau of Reclamation and Natural Resources Conservation Service, is implementing salinity control projects on irrigated lands throughout the watershed. It is important to recognize that data collection in support of this TMDL is an ongoing effort and that as new data is collected this TMDL will be revised as needed.

Wagenet, R.J. and J. Jurinak (1978). "Spatial variability of soluble salt content in a Mancos Shale watershed." Soil Science 126(6): 342-349.

A study was conducted to examine data collected in the micro watershed land process studies with regard to quantifying spatially variable soil properties. All 35 
sampling sites were classified as occurring on the Mancos shale formation within a $777 \mathrm{sq} \mathrm{km} \mathrm{(} 300 \mathrm{sq} \mathrm{mi}$ ) area of the Price River Basin. Samples were taken at 0$2.5,2.5-7.5$, and $7.5-15.0-\mathrm{cm}$ depths. Using the electrical conductivity (EC) of either the $1: 1$ or saturation extract as the salinity index parameter, it was found that EC values were distributed log-normally about the mean EC value of 35 observations. The coefficient of determination for the log-normal statistical plots was 1.00 for all three depths sampled at the 35 sites. The variance in the EC values increased with depth.

Whittig, L.D., A.E. Deyo, K.K. Tanji, and C.E. Higgins (1986). "Delineation and correlation of salinity to landforms and geologic formations, upper Colorado River Basins." Available from the National Technical Information Service, Springfield VA 22161, as PB86-176244/AS. Land, Air and Water Resources Paper No. 100012, July 1986. 143 p. 46 fig, 3 tab, 57 ref, 2 append. USGS Contract No. 1434-0001-0521.

This investigation was aimed at assessment of the potential contribution of dissolved mineral salts by natural lands in the Grand and Gunnison River Valleys in the Upper Colorado River Basin. The Mancos, Sego and Mount Garfield formations, are important contributors of soluble salts. Springs and seeps within the study area are highly localized, but result in significant differences in water quality and discharge between nearly identical adjoining watersheds. Active saline seeps and springs are common within the Grand Valley study section, but they are limited within the Gunnison River Valley study section. In some areas the springs reach salinity levels of $80 \mathrm{dSm}-1$. The majority of salts leave some local watersheds by groundwater flow through buried stream channels. The close correspondence between salinity and landforms provided the basis for construction of landform-salinity maps covering approximately $1070 \mathrm{sq} \mathrm{km}$ within the Grand Valley and Gunnison River Valleys. Salt-contributing seeps and springs were also located on a map of the Grand Valley section of the study area. To decrease the salinity contributions from the wildlands, it is proposed that: (1) good quality groundwater be intercepted and used locally or transported past highly saline areas; (2) saline groundwater, which reaches as high as 80 $\mathrm{dSm}-1$, be intercepted and transported to evaporation ponds; and (3) erosion resulting in sediment and salt production be controlled through use of gully plugs and sediment retention dams, reversing the present dissection of the pediments. This program would decrease erosion, sediment yield and salt yield while increasing wildland water and vegetation.

Whittig, L.D., A.E. Deyo and K.K. Tanji (1982 (PDF)). "Evaporite mineral species in Mancos Shale and salt efflorescence, Upper Colorado River basin." Soil Science Society of America Journal 46(3): 645-651.

Evaporite mineral species associated with Late Cretaceous marine sedimentary formations in a selected region of the Upper Colorado River Basin were identified by $x$-ray diffraction analysis. Mancos Shale, a major contributor of dissolved mineral salts to the Colorado River and several of its tributaries in the Upper Basin, contains abundant gypsum as the only detectable evaporite mineral. Salt efflorescence associated with the Mancos Shale, however, contains variable quantities of $\mathrm{Ca}, \mathrm{Na}$, and $\mathrm{Mg}$ sulfate evaporite species, including gypsum (CaSO4 2H2O), epsomite ( $\mathrm{Mg} 2 \mathrm{SO} 410 \mathrm{H} 2 \mathrm{O}$ ), hexahydrite (MgSO4 6H2O), pentahydrite (MgSO4 5H2O), starkeyite (leonhardtite) (MgSO4 4H2O), kieserite 
(MgSO4 H2O), loewite [Na4Mg2(SO4)4 5H2O], bloedite [ $\mathrm{Na2Mg}\left(\mathrm{SO}_{4}\right) 2$ o $4 \mathrm{H} 2 \mathrm{O}$ ], mirabilite $\left(\mathrm{NaSO}_{4} 10 \mathrm{H} 2 \mathrm{O}\right.$ ), and thenardite [Na2SO4). The hydrated sulfates of $\mathrm{Na}$ and $\mathrm{Mg}$, as very labile salts, are subject to change in response to relatively minor changes in temperature and moisture status. Dominant evaporite mineral species associated with a few localized seeps and springs emanating from the Late Cretaceous Mount Garfleld formation of the Mesaverde group, overlying the Mancos Shale, include soda $(\mathrm{Na} 2 \mathrm{CO} 3 \mathrm{10H} 2 \mathrm{O}$ ), trona ( $\mathrm{Na} 2 \mathrm{CO} 3$ $\mathrm{NaHCO} 32 \mathrm{H} 2 \mathrm{O}$ ), nahcolite $(\mathrm{NaHCO}$ ), and halite $(\mathrm{NaCl})$. Origin of the evaporite mineral species and their significance in relation to salt loading of the Colorado River are discussed.

Whittig, L.D., K.K. Tanji, J.W. Biggar, V.P. Evangelou, and A.E. Deyo (1983). "Salinity investigations in West Salt Creek, Colorado." Available from the National Technical Information Service, Springfield VA 22161 as PB83-203406, Price codes: A09 in paper copy, A01 in microfiche. California Water Resources Center Completion Report, Univ. of California, Davis, March 1983. 161 p. 46 Fig, 19 TTab, 87 Ref. OWRT B-201-CAL(2).

This investigation was aimed at assessment of the potential for contribution of dissolved mineral salts to the Colorado River by natural forces for contribution of dissolved mineral salts to the Colorado River by natural forces acting within a small, representative watershed in the Upper Colorado River Basin. The $440 \mathrm{~km}$ super 2 West Salt Creek watershed in west central Colorado was chosen for the study. Certain geologic strata and geomorphic landforms were identified as major contributors of dissolved mineral salts, whereas others within the watershed contribute little to the salt load of streams of the area. The Late Cretaceous marine Mancos Shale, in particular, is a principal contributor of soluble salts. In many areas, however, the saline Mancos shale is effectively protected from erosion and salt release by surface coverings of sandstone cuestas and pediment surfaces. High salt-hazard areas within the watershed are delineated and mapped.

Wright, W. G., and D.L. Butler (1993 (PDF)). "Distribution and mobilization of dissolved selenium in ground water of the irrigated Grand and Uncompahgre Valleys, western Colorado." in Allen, R.G., and Neale, C.M.U. (Eds.), Management of Irrigation and Drainage Systems--Integrated Perspectives: American Society of Civil Engineers, New York, p. 770-777.

Distribution of dissolved selenium in ground water of the irrigated Grand and Uncompahgre Valleys is affected by the aqueous geochemical environment of the shallow ground-water system composed of alluvium and shale residuum. Selenium concentrations are as high as 1300 micrograms per liter in water from shallow wells. The highest concentrations of dissolved selenium were in water from wells completed in alluvium overlying the Mancos Shale of Cretaceous Age, and the lowest concentrations were in water from wells completed in terrace deposits on the western side of the Uncompahgre Valley and in the water from wells completed in Mancos Shale residuum. Factors controlling the mobilization of dissolved selenium in the Grand and Uncompahgre Valleys could include oxidation/reduction, adsorption/desorption, and (or) ion exchange. Infiltration of irrigation water provides oxidizing conditions for mobilization of selenium from alluvium and shale residuum and transport to streams and irrigation drains tributary to the Uncompahgre, Gunnison and Colorado Rivers. 
Wright, W.G. (1999). "Oxidation and mobilization of selenium by nitrate in irrigation drainage." Journal of Environmental Quality 28(4): 1182-1187.

Selenium (Se) can be oxidized by nitrate (NO3-) from irrigation on Cretaceous marine shale in western Colorado. Dissolved Se concentrations are positively correlated with dissolved NO3- concentrations in surface water and ground water samples from irrigated areas. Redox conditions dominate in the mobilization of $\mathrm{Se}$ in marine shale hydrogeologic settings; dissolved Se concentrations increase with increasing platinum-electrode potentials. Theoretical calculations for the oxidation of Se by NO3- and oxygen show favorable Gibbs free energies for the oxidation of Se by NO3-, indicating NO3- can act as an electron acceptor for the oxidation of Se. Laboratory batch experiments were performed by adding Mancos Shale samples to zero-dissolved-oxygen water containing $0,5,50$, and $100 \mathrm{mg} / \mathrm{L} \mathrm{NO3-}$ as $\mathrm{N}(\mathrm{mg} \mathrm{Nn})$. Samples were incubated in airtight bottles at 25 degrees $\mathrm{C}$ for $188 \mathrm{~d}$; samples collected from the batch experiment bottles show increased $\mathrm{Sr}$ concentrations over time with increased NO3- concentrations. Pseudo first order rate constants for NO3- oxidation of Se ranged from 0.0007 to $0.0048 / \mathrm{d}$ for 0 to $100 \mathrm{mg} \mathrm{Nn} \mathrm{NO3-} \mathrm{concentrations,} \mathrm{respectively.} \mathrm{Management} \mathrm{of}$ $\mathrm{N}$ fertilizer applications in Cretaceous shale settings might help to control the oxidation and mobilization of $\mathrm{Se}$ and other trace constituents into the environment. 


\section{SOILS - EROSION - SEDIMENTATION}

Akram, M., and W.D. Kemper (1979 (PDF)). "Infiltration of soils as affected by the pressure and water content at the time of compaction." Soil Science Society of America Journal 43: 1080-1086.

Infiltration rates, volume reduction, and bulk densities of soils were determined as a function of compacting pressures and water content at the time of compaction. Maximum compaction generally occurred when the soils were packed at water contents near field capacity. When compacting loads were $<1$ $\mathrm{kg} / \mathrm{cm} 2$ the minimum bulk densities occurred when soils had water contents of about one half field capacity, indicating that surface tension of water films in the soils plays a major role in cohesiveness and stabilization against compaction under these conditions. Compacting loads of $3.46 \mathrm{~kg} / \mathrm{cm} 2$, at field capacity on sandy loams and finer textured soils, reduced infiltration rates to $<0.1 \%$ of values obtained after these soils had been compacted when they were air dried. In a loamy sand soil this reduction was $1 \%$. The low infiltration rates following compaction were increased by wetting and drying, although several cycles of wetting and drying did not raise the infiltration rate to the level observed before packing. Freezing and thawing cycles also increased the infiltration rates of previously compacted soils. Most of the change took place in the first freezing and thawing cycle. The large changes in infiltration rates using achievable levels of compaction at the "optimum" water contents indicate that compaction can play a major role in the management of water in ditches, reservoirs, furrows, and watersheds.

Branson, F. A. and J. B. Owen (1970). "Plant cover, runoff, and sediment yield relationships on Mancos Shale in western Colorado." Water Resources Research 6(3): 783-790.

Relationships between vegetation and hydrologic measurements for 17 watersheds near Grand Junction, Colorado, were subjected to correlation analyses. Six years of vegetation measurements, four vegetation measurement methods, and 15 years of hydrologic records were used in the analyses. Highly significant correlation coefficients were found for percent bare soil and runoff, but the relationships between bare soil and sediment yields were not statistically significant. Geomorphic parameters such as angle of junction, mean slope, drainage density, relief ratio, length-width ratio, and watershed area were more highly correlated with sediment yields than with runoff. Correlation coefficients for spring vegetation measurements and runoff were higher than for autumn measurements. First contact methods and step point vegetation measurement methods were superior to the loop method and the all contacts point method. Curves for the relationship of runoff to bare soil were strikingly different for three sets of watersheds from different precipitation zones. Bare soil measurements may provide rapid and inexpensive estimates of runoff for.

Canfield, H.E., V.L. Lopes, and D.C. Goodrich (2001). "Hillslope characteristics and particle size composition of surficial armoring on a semiarid watershed in the Southwestern United States." Catena 44(1): 1-11.

Distributed process-based hydrologic models have been used to describe and predict the movement of sediment on small watersheds. However, to 
parameterize these models requires an understanding of the spatial variability of erosion processes and the particle sizes of the sediment being moved. In this study, a high resolution digital elevation model (DEM) and detailed sediment particle sampling allowed a comparison of hillslope characteristics and particle sizes of surficial armoring in a semiarid watershed. Individual particle size classes on hillslopes are correlated with the underlying sediment type, local slope, aspect, and area draining through a grid element. The strongest correlations are between the underlying sediment and overlying sediment. However, the distribution of the particle size classes is consistent with a hydrodynamic explanation for sorting. In particular, increased area draining through a grid node and increased slope are correlated with higher concentrations of the $16-64-\mathrm{mm}$ particle size class. Both the coarsest and finest particle size classes are significantly correlated with the aspect of flow from a grid cell, with increased coarse particles and decreased fines on east-facing slopes. These spatial differences with aspect are attributed to dry season prevailing winds. These observations about process and spatial distribution are useful in predicting the spatial distribution of particles on the watershed for applications such as distributed hydrologic models.

Darboux, F., and C. Huang (2001 (PDF)). "Contrasting effects of surface roughness on erosion and runoff." Pp. 143-146 in Soil Erosion Research for the 21st Century, Proc. Int. Conf. (3-5 January 2001, Honolulu, Hawaii, USA), eds. J. C. Ascough II and D. C. Flanagan. St. Joseph, Michigan: ASAE. Pub. Date 3 January 2001. ASAE Pub \#701P0007.

Soil surface roughness is a key factor in affecting runoff generation and erosion. Nevertheless, contradictory results on the roughness effect are found in the literature: an increased soil roughness can either increase or decrease runoff and erosion. With the recent development of second-generation instantaneous-profile laser scanning technology, it is possible to acquire high-resolution soil microtopographic data rapidly, thus, enabling a further exploration of soil roughness effects on runoff and erosion. Additionally, the development of multiplebox system with controls for the near-surface hydraulic gradient allows us to quantify sediment mass balance relationships under different hydrologic conditions. This study is part of a project designed to identify conditions when soil roughness acts to either enhance or reduce erosion and to further explore how roughness elements interact with dominant erosion processes. The basic concepts are to split the random roughness in two sub-components based on their function and to characterize surface morphology considering the process scale. Simulated rainstorms were applied on the multiple-box system with different kinds of initial roughness, near-surface hydraulic gradient and feeding rate, to cover a wide range of transport conditions from detachment limited to transport limited. Surface microtopography was measured using an instantaneous-profile laser scanner. First results tend to show that a low density of aggregates reduces soil loss. These results will be completed in the near future and extended to others morphologies.

Gellis, A.C., R. Hereford, S. A. Schumm, and B. R. Hayes (1991). "Channel evolution and hydrologic variations in the Colorado River Basin - Factors influencing sediment and salt loads." Journal of Hydrology 124(3-4): 317-344. 
Suspended-sediment and dissolved-solid (salt) loads decreased after the early 1940 s in the Colorado Plateau portion of the Colorado River basin, although discharge of major rivers - the Colorado, Green and San Juan - did not change significantly. This decline followed a period of high sediment yield caused by arroyo cutting. Reduced sediment loads have previously been explained by a change in sediment sampling procedures or changes in climate, land-use and conservation practices. More recent work has revealed that both decreased sediment production and sediment storage in channels of tributary basins produced the decline of sediment and salt loads. Sediment production and sediment storage are important components of incised-channel evolution, which involves sequential channel deepening, widening and finally floodplain formation. Accordingly, the widespread arroyo incision of the late nineteenth century resulted initially in high sediment loads. Since then, loads have decreased as incised channels (arroyos) have stabilized and begun to aggrade. However, during the 1940s, a period of low peak discharges permitted vegetational colonization of the valley floors, which further reduced sediment loads and promoted channel stabilization. This explanation is supported by experimental studies and field observations. Both geomorphic and hydrologic factors contributed to sediment storage and decreased sediment and salt loads in the upper Colorado River basin.

Gellis, A. C., A. Cheama, V. Laahty, and S. Lalio (1995). "Assessment of gullycontrol structures in the Rio-Nutria watershed, Zuni Reservation, New-Mexico." Water Resources Bulletin 31(4): 633-646.

During the latter part of the 19th century and the early part of the 20th century, a major cycle of erosion, arroyo cutting, and gullying occurred in the southwestern United States. Since this erosion cycle began, many projects to control erosion, such as the Civilian Conservation Corps projects in the 1930s, were initiated. However, in the Southwestern United States few studies have documented the effect of these structures in reducing erosion or their effect on gully systems. As part of a watershed rehabilitation project on the Zuni Reservation, New Mexico, 47 structures made either of earth or rocks and 23 rock and brush structures were assessed. Sixty percent of the 47 earth or rock structures have breached and relative to dam height, 65 percent of 47 structures are more than 50 percent silted. Of the 23 rock and brush structures, 22 percent have breached or are close to breaching. Reasons for breaching of all structural types may be piping, scour immediately below the structures, large runoff and large drainage area, poor maintenance, headcutting, and active arroyo deepening and widening. In most cases, documentation does not exist on structure design, the specific purpose for a structure, or when these structures were built.

Gellis, A.C. (1996). "Gullying at the Petroglyph National Monument, New Mexico." Journal of Soil and Water Conservation 51(2): 155-159.

Fifty gullies were mapped along a $32 \mathrm{~km}(20 \mathrm{mi})$ escarpment in the Petroglyph National Monument, New Mexico, of which 14 were located along dirt roads, 7 along foot and bicycle trails, 18 on undisturbed hillslopes, and 11 part of a natural channel network. The dirt road and foot and bicycle trails channel surface runoff and increase erosion. Thirty of 50 gullies assessed received runoff from the dirt road. Ten gullies mapped in 1991 were not evident on 1987 aerial photographs and may have been formed during 1987 to 1991 . Natural factors such as high- 
intensity rain storms during the intervening period were thought to have initiated or increased erosion and gullying in the National Monument. Analyses of storm data during this period indicated that most storms had recurrence intervals of 2 years or less for rainfall intensity measured in millimeters per 30-minute, 1-hour and 2-hour durations. An exception was a storm on July 28, 1987, that for a 1hour period had a recurrence interval of 25 years. However, the rainfall for this storm was highly localized falling in the southern portion of the monument and not in the vicinity of the 10 new gullies. Results from this study show the sensitivity of semiarid landscapes to certain forms of development, such that storms with recurrence intervals of 2 years or less might cause considerable erosion.

Gellis, A.C., M.J. Pavich, P.R. Bierman, E.M. Clapp, A. Ellevein and S. Aby (2004 (PDF)). "Modern sediment yield compared to geologic rates of sediment production in a semi-arid basin, New Mexico: Assessing the human impact." Earth Surface Processes and Landforms 29(11): 1359-1372.

In the semi-arid Arroyo Chavez basin of New Mexico, a $2.28 \mathrm{~km}(2)$ sub-basin of the Rio Puerco, we contrasted short-term rates (3 years) of sediment yield measured with sediment traps and dams with long-term, geologic rates (similar to 10,000 years) of sediment production measured using Be-10. Examination of erosion rates at different time-scales provides the opportunity to contrast the human impact on erosion with background or geologic rates of sediment production. Arroyo Chavez is grazed and we were interested in whether differences in erosion rates observed at the two time-scales are due to grazing. The geologic rate of sediment production, $0.27 \mathrm{~kg} \mathrm{~m}(-2) \mathrm{a}(-1)$ is similar to the modern sediment yields measured for geomorphic surfaces including colluvial slopes, gently sloping hillslopes, and the mesa top which ranged from 0.12 to $1.03 \mathrm{~kg} \mathrm{~m}(-2) \mathrm{a}(-1)$. The differences between modern sediment yield and geologic rates of sediment production were most noticeable for the alluvial valley floor, which had modern sediment yields as high as $3() .35 \mathrm{~kg} \mathrm{~m}(-2)$ a(-1). The hydraulic state of the arroyo determines whether the alluvial valley floor is aggrading or degrading. Arroyo Chavez is incised and the alluvial valley floor is gullied and piped and is a source of sediment. The alluvial valley floor is also the portion of the basin most modified by human disturbance including grazing and gas pipeline activity, both of which serve to increase erosion rates.

Gifford, G.E., D.B. Thomas, and G.B. Colthart (1977 (PDF)). "Effects of gully plugs and contour furrows on erosion and sedimentation in Cisco Basin, Utah." Journal of Range Management 30(4): 290-292.

The effects of contour furrows and gully plugs on erosion and sedimentation within the Cisco Basin, Utah, were evaluated. Soils studied were less than $10 \mathrm{~cm}$ deep and had developed from Mancos Shale and sandstone. When combined, contour furrows and gully plugs held all runoff and sediment. Contour furrows alone were only able to hold a portion of the runoff and sediment. Expected life of the contour furrows ranges from 6 to 12 years, while that of the gully plugs is from 14 to 33 years.

Godfrey, A.E. (1997 (PDF)). "Mass movement of Mancos Shale crust near Caineville, Utah: A 30-year record." Geografiska Annaler Series a-Physical Geography 79A(3): 185-194. 
Rates of soil creep were studied periodically over a 30-year period in southeastern Utah on Mancos Shale badland slopes averaging 35 degrees. More intensive studies were carried out over a 10-year period on slopes averaging 40 degrees. On the 35 degree slope the average rate of movement was $2.71 \mathrm{~cm}$ yr(1) On the 40 degree slopes, rates varied from 3.14 to $5.94 \mathrm{~cm}$ yr(-1). Individual rates of movement varied widely, but average movement of a given line was consistent. No statistical differences in rates of movement were found between north- and south-facing slopes. About two-thirds of the total movement occurred during the winter/spring period; episodes of rapid movement coincided with years in which storms deposited at least $0.6 \mathrm{~cm}$ of precipitation per day for at least two consecutive days. Downslope rotation of nails indicates that creep involves only the top few centimeters of soil.

Howard, A.D. (1997 (PDF)). "Badland morphology and evolution: Interpretation using a simulation model." Earth Surface Processes and Landforms 22(3): 211 227.

A drainage basin simulation model is used to interpret the morphometry and historical evolution of Mancos Shale badlands in Utah. High relief slopes in these badlands feature narrow divides and linear profiles due to threshold masswasting. Threshold slopes become longer in proportion to erosion rate, implying lower drainage density and higher relief. By contrast, in slowly eroding areas of low relief, both model results and observations indicate that drainage density increases with relief, suggesting control by critical shear stress. Field relationships and simulation modeling indicate that the badlands have resulted from rapid downcutting of the master drainage below an Early Wisconsin terrace to the present river level, followed by base level stability. As a result, Early Wisconsin alluvial surfaces on the shale have been dissected up to $62 \mathrm{~m}$ into steep badlands, and a Holocene alluvial surface is gradually replacing the badland slopes which are eroding by parallel retreat.

Simanton, J.R., M.A. Weltz and H.D. Larsen (1991). "Rangeland experiments to parameterize the water erosion prediction project model - vegetation canopy cover effects." Journal of Range Management 44(3): 276-282.

The Water Erosion Prediction Project (WEPP) is a new water erosion prediction technology being developed by the USDA-Agricultural Research Service to replace the Universal Soil Loss Equation. Rangeland field experiments were designed to parameterize the WEPP rangeland erosion model. Included in the field experiments were plot treatments designed to separate direct from indirect effects of vegetation canopy on runoff and soil erosion. Nine rangeland sites from a wide range of soil and vegetation types were evaluated using rainfall simulation techniques. Natural versus clipped treatment surface characteristics and runoff and erosion responses were compared using regression analyses. These analyses showed that there were no significant differences between natural and clipped plot surface characteristics, runoff ratios, final infiltration rates, or initial rainfall abstractions. Erosion rates were different between treatments with the clipped plots having slightly less erosion than the natural plots. Results indicated that, under the rainfall conditions simulated, canopy cover was not directly contributing to initial abstractions through rainfall interception loss or significantly affecting runoff or erosion. 


\section{DISTURBANCE}

Adams, J.A., E.S. Endo, L.H. Stolvy, P.G. Rowlands, and H.B. Johnson (1982 (PDF)). "Controlled experiments on soil compaction produced by off-road vehicles in the Mojave Desert, California." Journal of Applied Ecology 19(1): 167175.

Soil compaction is being caused by intensive use of off-road recreational vehicles in the California deserts. Vehicle tracks produced by different numbers of motorcycle and four-wheel drive passes were made on the Mojave Desert of California on both Typic Haplargid and a Typic Torripsamment soil in an attempt to estimate minimum amounts of soil compaction which may produce significant reductions in growth of desert annual plants. A motorcycle produced much smaller increases in soil strength than did a four-wheel drive vehicle. Soil strength of drying compacted soil (even slightly compacted soil) increased at a much greater rate than soil strength of drying uncompacted soil. This may be an explanation for observed reductions in annual desert plant growth even on areas with a relatively small amount of compaction.

Belnap, J. (1995 (PDF)). "Surface disturbances: Their role in accelerating desertification." Environmental Monitoring and Assessment 37(1-3): 39-57.

Maintaining soil stability and normal water and nutrient cycles in desert systems is critical to avoiding desertification. These particular ecosystem processes are threatened by trampling of livestock and people, and by off-road vehicle use. Soil compaction and disruption of cryptobiotic soil surfaces (composed of cyanobacteria, lichens, and mosses) can result in decreased water availability to vascular plants through decreased water infiltration and increased albedo with possible decreased precipitation. Surface disturbance may also cause accelerated soil loss through wind and water erosion and decreased diversity and abundance of soil biota. In addition, nutrient cycles can be altered through lowered nitrogen and carbon inputs and slowed decomposition of soil organic matter, resulting in lower nutrient levels in associated vascular plants. Some cold desert systems may be especially susceptible to these disruptions due to the paucity of surface-rooting vascular plants for soil stabilization, fewer nitrogenfixing higher plants, and lower soil temperatures, which slow nutrient cycles. Desert soils may recover slowly from surface disturbances, resulting in increased vulnerability to desertification. Recovery from compaction and decreased soil stability is estimated to take several hundred years. Re-establishment rates for soil bacterial and fungal populations are not known. The nitrogen fixation capability of soil requires at least 50 years to recover. Recovery of crusts can be hampered by large amounts of moving sediment, and re-establishment can be extremely difficult in some areas. Given the sensitivity of these resources and slow recovery times, desertification threatens million of hectares of semiarid lands in the United States.

Belnap, J. (1996 (PDF)). "Soil surface disturbances in cold deserts: Effects on nitrogenase activity in cyanobacterial-lichen soil crusts." Biology and Fertility of Soils 23(4): 362-367.

Cyanobacterial-lichen soil crusts can be a dominant source of nitrogen for colddesert ecosystems. Effects of surface disturbance from footprints, bike and 
vehicle tracks on the nitrogenase activity in these crusts was investigated. Surface disturbances reduced nitrogenase activity by $30-100 \%$. Crusts dominated by the cyanobacterium Microcoleus vaginatus on sandy soils were the most susceptible to disruption; crusts on gypsiferous soils were the least susceptible. Crusts where the soil lichen Collema tenax was present showed less immediate effects; however, nitrogenase activity still declined over time. Levels of nitrogenase activity reduction were affected by the degree of soil disruption and whether sites were dominated by cyanobacteria with or without heterocysts. Consequently, anthropogenic surface disturbances may have serious implications for nitrogen budgets in these ecosystems.

Belnap, J. (2002 (PDF)). "Impacts of off road vehicles on nitrogen cycles in biological soil crusts: resistance in different US deserts." Journal of Arid Environments 52(2): 155-165.

Biological soil crusts are an important component of desert ecosystems, as they influence soil stability and fertility. This study examined and compared the shortterm vehicular impacts on lichen cover and nitrogenase activity (NA) of biological soil crusts. Experimental disturbance was applied to different types of soil in regions throughout the western U.S. (Great Basin, Colorado Plateau, Sonoran, Chihuahuan, and Mojave deserts). Results show that pre-disturbance cover of soil lichens is significantly correlated with the silt content of soils, and negatively correlated with sand and clay. While disturbance appeared to reduce NA at all sites, differences were statistically significant at only 12 of the 26 sites. Cool desert sites showed a greater decline than hot desert sites, which may indicate non-heterocystic cyanobacterial species are more susceptible to disturbance than non-heterocystic species. Sandy soils showed greater reduction of NA as sand content increased, while fine-textured soils showed a greater decline as sand content increased. At all sites, higher NA before the disturbance resulted in less impact to NA post-disturbance. These results may be useful in predicting the impacts of off road vehicles in different regions and different soils.

Belnap, J. and D.A. Gillette (1997 (PDF)). "Disturbance of biological soil crusts: Impacts on potential wind erodibility of sandy desert soils in southeastern Utah." Land Degradation \& Development 8(4): 355-362.

Friction threshold velocities (FTVs) were determined for biological soil crusts in different stages of recovery. Particles on the surface of crusts that had been relatively undisturbed for at least 20 years were found to have significantly higher FTVs than those that had been disturbed 5,10 or 1 years previously $(376,87$, and $46 \mathrm{~cm}$ sec(-1) respectively). FTVs for crust breakage was also much higher for undisturbed crusts when compared to the previously disturbed crusts (573, 148 , and $88 \mathrm{~cm} \mathrm{sec}(-1)$ respectively). All crusted surfaces were more stable than ban sand, which had an FTV of $16 \mathrm{~cm} \mathrm{sec}(-1)$ Disturbance treatments were then applied to the three crustal classes. Disturbance significantly reduced the FTVs of all classes by 73-92 per cent. Comparing crustal FTVs with mean and high monthly wind speeds found in this region, it was observed that only crusts that had been undisturbed for approximately 20 years or more were able to protect soil surfaces from wind gusts expected on the average of once a month. Other crustal classes, as well as all disturbance treatments, had FTVs lower or equal to that of commonly occurring winds in this region. Because most of the crustal 
biomass occurs in the top $0.3 \mathrm{~mm}$ of soils, even slight soil loss can negatively influence stability and nutrient inputs to this ecosystem.

Belnap, J., K.T. Harper, and S.D. Warren (1994). "Surface disturbance of cryptobiotic soil crusts - nitrogenase activity, chlorophyll content, and chlorophyll degradation." Arid Soil Research and Rehabilitation 8(1): 1-8.

Cryptobiotic soil crusts are an important component of semiarid and arid ecosystems. An important role of these crusts is the contribution of fixed nitrogen to cold-desert ecosystems. This study examines the residual effects of various intensities and combinations of different surface disturbances (raking, scalping, and tracked vehicles) on nitrogenase activity, chlorophyll content, and chlorophyll degradation in these soil crusts. Nine months after disturbance chlorophyll content of disturbed soils was not statistically different from undisturbed controls, except in the scalped treatments, indicating recovery of this characteristic is fairly quick unless surface material is removed. Differences in chlorophyll degradation among treatments were not statistically significant. However, nitrogenase activity in all treatments showed tremendous reductions, ranging from $77-97 \%$, when compared to the control, indicating this characteristic is slow to recover. Consequently, assessment of crustal recovery, from disturbance must include not only visual and biomass characteristics but other physiological measurements as well. Areas dominated by these crusts should be managed conservatively until the implications of crustal disturbance is better understood.

Belnap, J. and S. D. Warren (2002 (PDF)). "Patton's tracks in the Mojave Desert, USA: An ecological legacy." Arid Land Research and Management 16(3): 245258.

Recovery of soil properties from World War II-era military training exercises in the Mojave Desert was measured approximately 55 years following disturbance. Tracks from military vehicles were still visible, particularly in areas of desert pavement. Soil penetrability was much lower in visible tracks than outside the tracks. Soils in tracks had fewer rocks in the top $10 \mathrm{~cm}$ of the soil profile than adjacent untracked soils. Larger particles $(>4.8 \mathrm{~mm}$ ) formed a moderately welldeveloped pavement outside of the tracks, while smaller, loose particles (less than or equal to $4.8 \mathrm{~mm}$ ) dominated the surface of the tracks. The time required to restore the desert pavement is likely to he measured in centuries. Based on biomass estimates, the cyanobacterial component of biological soil crusts had recovered $46-65 \%$ in tracks, compared to outside the tracks. Overall recovery of lichen cover has been much slower. Under plant canopies, cover of Collema tenax was not significantly different between areas inside and outside the tracks; however, recovery of Canapyrenium squamulosum was only $36 \%$. In plant interspaces with less favorable moisture and temperature conditions, $\mathrm{C}$. tenax showed a $6 \%$ recovery and $C$. squamulosum a $3 \%$ recovery. Assuming recover of the biological soil crust is linear, and complete only when the most sensitive species (C. squamulosum) has fully recovered in the most limiting microhabitats (plant into-spaces), it may require almost two millennia for full recovery of these areas.

Dohrenwend, J.C. (2003 (PDF)). "Accelerated erosion in areas disturbed by OHV activity in the Mancos Shale badlands of the Factory Butte-North Caineville Mesa 
area, Wayne County, Utah." Report prepared for Richfield Field Office Bureau of Land Management.

This study is a preliminary assessment of the erosional impacts of OHV use in the Mancos Shale badlands of the Caineville area of central Wayne County, Utah. This assessment is based on a comparative geomorphic analysis of the microtopographic characteristics of undisturbed versus heavily disturbed hillslopes in these badlands. This comparative analysis focuses on a determination of what is present in the undisturbed landscape but is missing from disturbed areas. Therefore, it provides a direct determination of the additional erosion that has occurred in the disturbed areas. Three geomorphic elements characteristic of the natural, undisturbed hillslopes within the Caineville badlands were identified and measured: surface soil crust, rills and small gullies, and the hillslope mantel of soil and colluvium. Soil crust relief averages approximately 1.5 inches on undisturbed slopes; but soil crust is not present on heavily disturbed hillslopes. Rill depth averages 3.1 inches on undisturbed hillslopes; but rills and small gullies are not present on heavily disturbed hillslopes. The thickness of soil and colluvium averages 5 inches on undisturbed hillslopes. Structured soil and colluvium are not present on heavily disturbed hillslopes. Instead, these slopes are covered by a thin mantel of pulverized rock and soil with an average thickness of 1.9 inches. The absence of soil crust, rills and small gullies, and soilcolluvium on hillslopes that have been heavily disturbed by OHV activity demonstrates that at least 3 inches of additional erosion has occurred on these hillslopes as compared to natural, undisturbed slopes. This amount of additional erosion is equivalent to a soil loss of one million pounds ( 500 tons) per hillslope acre; and this additional erosion has been occurring at a rate that is approximately five times higher than the natural (late Quaternary) erosion rate in the Caineville badlands.

Durbin, T.D., M.R. Smith, R.D. Wilson, and S.H. Rhee (2004). "In-use activity measurements for off-road motorcycles and all-terrain vehicles." Transportation Research Part D-Transport and Environment 9(3): 209-219.

Off-road recreation vehicles are an important source of emissions and make a disproportionately high contribution to the emissions inventory. Here 58 off-road motorcycles and 39 all-terrain vehicles (ATVs) were instrumented to collect activity data. The activity data for motorcycles and ATVs varied significantly depending on the type of terrain, the type of off highway vehicle, and personal riding habits. The most rapid transitions in speed were typically observed for motorcycles operated on motocross tracks or in trail riding. Over similar terrain, motorcycles had slightly higher top speeds than the ATVs. The highest observed speeds were for motorcycles in open terrain riding conditions. Interestingly, average speeds were comparable between different types of terrain. (C) 2004 Elsevier Ltd. All rights reserved.

Eckert, R.E. Jr., M.K. Wood, W.H. Blackburn, and F.F. Peterson (1979 (PDF)). "Impacts of off-road vehicles on infiltration and sediment production of two desert soils." Journal of Range Management 32(5): 394-397.

Impacts of motorcycle and 4-wheel drive truck traffic on infiltration rate and sediment production were evaluated on two desert soils. Infiltration was similar for both soils; however, more sediment was produced from a surface with exposed mineral soil than from a gravel-mulched surface. Infiltration was 3 to 13 
times greater on the coppice soil beneath shrubs than on interspace soil between shrubs, but sedimentation was 10 to 20 times greater on interspace soil. Infiltration was less and sediment yield was greater after soil was disturbed by vehicular traffic, and after reformation of the surface crust, particularly on interspace soil. High sediment production from interspace soil was attributed to reduced infiltration after 10 minutes. The soil then became saturated and unstable, was dispersed by raindrop impact, and particles were carried in runoff water for the remaining 20 minutes of the test period. Coppice soil had a high infiltration rate for the entire test period and did not become saturated. In addition, the high organic matter and aggregate stability of coppice soil prevented soil movement, though some runoff occurred.

Iverson, R. M. (1980 (PDF)). "Processes of accelerated pluvial erosion on desert hillslopes modified by vehicular traffic." Earth Surface Processes 5: 369-388.

Accelerated pluvial erosion on hillslopes modified by off-road vehicles (ORVs) is analyzed using results from 50 rainfall simulation experiments conducted in the Mojave Desert, California. Sediment yield from $1 \mathrm{~m} 2$ hillslope plots subjected to intense, 20-minute rainfalls is typically increased 10 to 20 -fold following ORV use. Salient effects of vehicle traffic, which reduce infiltration, increase runoff sediment transport efficiency, and enhance gully formation, are further studied by combining simple theoretical relations with experimental data. This analysis helps identify factors controlling erosion on natural desert hillslopes, as well as those used by ORVs. Erosion of natural or vehicle-used desert surfaces is heavily influenced by runoff hydraulics. Calculated Darcy-Weisbach friction factors decrease by an average of 13 -fold following vehicular slope modification, whereas runoff Reynolds numbers increase by an average of 5.5 fold. The capacity of overland flow to transport sediment is related to runoff power and its degree of localization, which usually increase considerably following ORV activity; however, the ability of overland flow to move large grains (competency) is related to a combination of factors not always systematically influenced by ORV use. Kinematic runoff routing, which is used to extrapolate experimental results to longer slope lengths, leads to the suggestion that the hydraulic roughness of desert hillslopes strongly influences their erosional behavior.

Lacey, R.M., H.E. Balbach, R.S. Baran, and R. Graff (1980 (PDF)). "Evaluation of areas for off-road recreational motorcycle use. Volume I: Evaluation method." Report. US Army Corps of Engineers. Technical Report N-86, Vol I, November. 1980, U.S. Army Construction Engineering Research Laboratory

Based on user demands for more areas on which to operate off-road recreational motorcycles (trailbikes), and to respond to Presidential Executive Order which require that Federally owned land be evaluated for such use, an evaluation process was developed for Army land managers to systematically make such use determinations. Volume I of this report describes the method developed by the U.S. Army Construction Engineering Research Laboratory (CERL) for this purpose

Lacey, R.M., and H.E. Balbach (1980 (PDF)). "Evaluation of areas for off-road recreation motorcycle use. Volume II: Alternate soil suitability determination methods." Report. US Army Corps of Engineers. Technical Report N-86, Vol II, November, 1980, U.S. Army Construction Engineering Research Laboratory 
Based on user demands for more areas on which to operate off-road recreational motorcycles (trailbikes), and to respond to Presidential Executive Order which require that Federally owned land be evaluated for such use, an evaluation process was developed for Army land managers to systematically make such use determinations. Volume II of this report illustrates and describes seven alternative soil evaluation methods developed by the U.S. Army Construction Engineering Research Laboratory (CERL). Each method is defined as more or less useful in terms of its reliability and the ease and speed by which its results may be obtained. Included are descriptions of simple ways to conduct the field and laboratory soil analysis required when using alternative soil evaluation methods.

Leet, C.W. (1986). "Historical BLM Mancos Shale management in NW, CO." Proceedings of the Fourth Federal Interagency Sedimentation Conference March 24-27. Nevada. Volume I 9 ref. I.

The Bureau of Land Management (BLM) has been implementing salinity and erosion control structures in the Lower Wolf Creek (LWC) watershed for the past 40 years. The LWC watershed has a semi-arid climate and sparse vegetation. It is characterized by highly erodible Mancos Shale, a marine sedimentary formation that is exposed on the surface and contains a high concentration of soluble salts. In this 31,858 -ha $(78,720$-acre) watershed, about 80 projects have been completed to reduce erosion which accelerated because of overgrazing by cattle, sheep, and horses, from approximately 1897 to 1936 . Project work was started in 1938 by the Civilian Conservation Corps (CCC) and has continued sporadically by the BLM to the present. Stabilization techniques include contour furrows, reseedings, spreader dikes, detention and retention dams, pit reservoirs, and gully plugs. Many of the original erosion control projects have silted full, but most are still functional in slowing runoff velocities and depositing sediment. Some of the old reservoirs have spillways that are too steep, and the spillways are eroding into the existing reservoirs and are threatening the stability of the stored sediment. In 1984 the Lower Creek Watershed Management Plan (LWC WMP) was written to develop a systematic approach to salinity and erosion control from the discontinuous and continuous gully systems on the Mancos Shale Formation. The watershed was divided into treatment units for project implementation. Hypalon drop structures and new pit reservoirs are being designed for construction in 1985, and in the future, as funds become available for salinity control, and for the establishment of riparian habitat.

Lusby G.C., G. T. T., J.R. Thompson, and V.H. Reid (1963 (PDF)). "Hydrologic and biotic characteristics of grazed and ungrazed watersheds of the Badger Wash Basin in western Colorado, 1953-58." Geological Survey Water-Supply Paper 1532-B in cooperation with USDA, Forest Service, U.S.D.I., Fish and Wildlife Service, the Bureau of Land Management, and Bureau of Reclamation.

A comprehensive study of the hydrologic and biotic characteristics of small drainage basins on the Colorado Plateau and the effect of grazing on these characteristics was begun in 1953, in an area consisting predominantly of Mancos Shale derived soils and sediments. This report presents data obtained during the first 5 years of the proposed 20-year study. Periodic observations were made at permanent transects in 8 paired fenced and unfenced watersheds to characterize plant and ground cover, determine degree of use by livestock and 
measure changes in watershed cover. Results after 5 years of study indicate that changes in watershed cover have been relatively small on both grazed and ungrazed areas. Changes that did take place were mainly on shale and mixed type soil. Ground-cover index on mixed type soil was significantly higher, 4 percent, on ungrazed areas at the end of the 5 years. Plot records were obtained using the Rocky Mountain Infiltrometer at 12 plots in each of the 8 study watersheds to determine the effect of livestock exclusion on infiltration and sheet erosion. Infiltration rates for the last 20 minutes of both the wet and dry runs were significantly higher in 1958 than they were 5 years before, but this difference was not associated with treatment because rates on both grazed and ungrazed plots increased about the same amount. The initial water-absorbing capacity increased significantly on ungrazed plots. No change in erosion rates was observed. Rainfall was variable and below normal during 4 of the first 5 years of study. Runoff was produced mainly by thunderstorms during the summer months and was characterized by high rates of flow for short periods. Comparison of runoff in grazed and ungrazed watersheds indicates a change in the relationship between precipitation and runoff resulting from the exclusion of livestock. More sediment per unit area was produced during the 5 years of study from grazed areas than from ungrazed areas. No definitive trend in small mammal population on grazed and ungrazed watersheds has yet been determined

Lusby, G.C., V.H. Reid, and O.D. Knipe (1971 (PDF)). "Effects of grazing on the hydrology and biology of the Badger Wash Basin in western Colorado, 1953-66." Geological Survey Water-Supply Paper 1532-D in cooperation with USDA. Forest Service, U.S.D.I., Fish and Wildlife Service, the Bureau of Land Management, and Bureau of Reclamation.

An intensive study of the effect of grazing on the hydrologic and biotic characteristics of small drainage basins on the Colorado Plateau was begun on the fall of 1953 in an area consisting predominantly of Mancos Shale derived soils and sediments. This report presents data obtained during the first 13 years of the proposed 20-years study. For the period of record 1954-66, runoff from grazed watersheds has averaged about 33 acre-feet per square mile per year. Runoff from ungrazed watersheds averaged from 71 to 76 percent of that from grazed watersheds. During the last 6 years of the period, however, ungrazed watersheds produced 69 to 71 percent as much runoff as grazed watersheds. The runoff from grazed watersheds during the same period was about 3 acre-feet per square mile per year. Sediment yield from ungrazed watersheds ranged from 51 to 75 percent of that from grazed watersheds and averaged 66 percent. The largest change in these relations occurred 2 years after livestock were excluded from certain watersheds. The causative factors for changes in the runoff and sediment yield relations are not entirely clear. At the end of 13 years, a significant change had occurred in the amount of bare soil and rock, in the ground-cover index, and in the litter and moss components of the grazed watersheds. These items remained essentially unchanged on ungrazed watersheds. The changes in ground-cover factors were not of large magnitude and did not occur at the same rate as the changes of runoff and sediment yield. A large part of the difference appears to have been caused by a change in the structure of surface soil, which was brought about by the elimination of trampling by livestock. Deer mice were the most common rodent present on the 
experimental watersheds, but even their population was not great enough to affect the composition of range vegetation. Deer mice populations remained comparable on grazed and ungrazed watersheds during the study. Other rodents were not present in sufficient numbers to allow their comparison on grazed and ungrazed range. Desert cottontail rabbits and black-tailed jackrabbits were more plentiful in ungrazed watersheds but were not present in large enough numbers to affect range vegetation.

Lusby, G.C. (1979 (PDF)). "Effects of grazing on runoff and sediment yield from desert rangeland at Badger Wash in western Colorado, 1953-73." Geological Survey Water-Supply Paper 1532-I in cooperation with the Bureau of Land Management.

Four different systems of livestock management were compared hydrologically during a 20-year study (November 1953-November 1973) in western Colorado in an area consisting predominantly of Mancos Shale derived soils and sediments. These systems consisted of grazing by cattle and sheep from November 15 to May 15 each year, complete elimination of grazing, grazing by sheep from November 15 to February 15 each year, and grazing by sheep from November 15 to February 15 every other year. Grazing by both cattle and sheep from November 15 to May 15 each year was the standard grazing practice in the area at the beginning of the study. Complete grazing exclusion resulted in a reduction in runoff of about 20 percent during the period 1953-65 and an additional 20 percent during 1966-73. During the same periods sediment yield was reduced by 35 and 28 percent, respectively, for a total of 63 percent. A change in grazing use from cattle and sheep, November 15-May 15 each year, to sheep only at approximately the same utilization rate, November 15-February 15 each year, was accompanied by a reduction in runoff and sediment yield of about 29 percent. The same change in use, except that grazing was allowed every other year during the sheep grazing period, resulted in a reduction in runoff and sediment yield of about 20 percent. Recurrence intervals of annual runoff occurring on three soil types at Badger Wash are provided. These data may be applied to similar soils in areas of like climate and physiography shown on accompanying maps.

Lusby, G.C. (1979 (PDF)). "Effects of converting sagebrush cover to grass on the hydrology of small watersheds at Boco Mountain, Colorado." Geological Survey Water-Supply Paper 1532-J in cooperation with the Bureau of Land Management.

Changes in runoff and sediment yield caused by changing sagebrush cover to grass cover were studied at four small watersheds in western Colorado during a 9-year period, from 1965 to 1973 in an area consisting predominantly of Mancos Shale derived soils and sediments. Measurements of runoff and sediment yield from the four watersheds were made for 3 years, at which time two watersheds were plowed and seeded to beardless bluebunch wheatgrass. The same measurements were then continued for an additional 6 years. Measurements indicated that conversion to grass caused a reduction in runoff from summer rainstorms of about 75 percent. Runoff from spring snowmelt increased about 12 percent, and annual runoff from treated watersheds decreased about 20 percent when compared with control watersheds. Sediment yield from the seeded watersheds was reduced by about 80 percent; most of this reduction is related to 
the decrease in runoff from summer rainstorms. The size of barren interspaces between plants was reduced on the converted watersheds to about 30 percent of those on the untreated watersheds. Linear regression analysis indicates that a reduction of 38 percent in the amount of bare soil resulting from planting grass would result in a decrease of 73 percent in sediment concentration.

Prose, D.V., and H.G. Wilshire (2000 (PDF)). "The lasting effects of tank maneuvers on desert soils and intershrub flora." U.S. Department of the Interior. U.S. Geological Survey. Open-File Report OF 00-512.

Mojave Desert soils and intershrub flora sustained lasting disturbances during military training maneuvers initiated by General George Patton, Jr. in the 1940s, and during Operation Desert Strike in 1964. At six sites, mean desert pavement clast size was significantly smaller by $15 \%$ to $50 \%$ in single tank tracks compared to undisturbed surfaces. The finer-grained tracks yielded significantly higher surface reflectance values at two of three sites. At one site, Patton era tank tracks cross centuries-old "intaglios" and there was no significant difference in clast size between the disturbances. Full recovery of pavement surfaces may require a change in climate since pavements formed in Pleistocene times under climatic conditions that no longer exist. Tank tracks of both ages exhibited significant levels of soil compaction, as indicated by penetrometer resistance values that were $51 \%$ to $120 \%$ greater than those in undisturbed soils to $0.3 \mathrm{~m}$ depth. Soil bulk density in tracks was $4 \%$ to $6 \%$ higher than in undisturbed soils. Soil compaction lowered infiltration rates in tank tracks by $24 \%$ to $55 \%$ in comparison to undisturbed soils. Compaction has prevented the intershrub flora from recovering in tank tracks. Annual and herbaceous perennial plant density was higher by $13 \%$ to $56 \%$ in tank tracks than in undisturbed soils, but compaction has restricted the growth of individual plants. This was reflected in plant cover values, which were $3 \%$ to $16 \%$ lower in tank tracks than in undisturbed soils. Soil compaction also altered the species composition. Species with long taproots, such as Chaenactis fremontii, were reduced in density and cover in tank tracks, whereas grass species with shallow, fibrous root systems had large density increases in tracks. Another important element of the intershrub flora, cryptobiotic crust, exhibited a low rate of recovery from the impact of tank travel at one site. The cover of the most well-developed component of the crusts, growing on delicate soil pedicels in undisturbed soils, was reduced by $50 \%$ in tank tracks because of destruction and compaction of the uppermost soil layers.

Raghaven, G.S.V., E. McKyes, I. Amir, M. Chasse, and R.S. Broughton (1976 (PDF)). "Prediction of soil compaction due to off-road vehicle traffic." Transactions of the American Society of Agricultural Engineers 19(4): 610-613.

Simultaneous field and laboratory compaction data were examined in order to determine the prediction possibilities. Several existing theories were also considered for comparison. An equation representing dry density in terms of applied pressure and moisture content was used to describe the field and laboratory data. The pressure application on the agricultural soil varied from near 0 to $1.62 \mathrm{~kg} / \mathrm{cm} 2$, and field data obtained at various moisture contents provided necessary information for arriving at the laboratory index test methods. The pattern of real compaction under tire loads was found to compare well with 
the standard Proctor compaction test. Results of such attempts are very useful for off-road machinery designers and farmers.

Snyder, C. T., D.G. Frickel, R.F. Hadley, and R.F. Miller (1976). "Effects of offroad vehicle use on the hydrology and landscape of arid environments in central and southern California." U.S Geological Survey. Water Resources Investigations 76-99.

Two widely separated sites in California used for motorcycle hillclimbing were studied to evaluate the impact on the landscape and hydrology. At panoche Hills in central California, an area formely used by motorcycles together with an adjacent unused area were monitored from 1971 to 1975 . Observations in both areas included measurements of precipitation, runoff, soil moisture; soil bulk density, plant cover, and erosion surveys. At Dove Spring Canyon in southern California erosion was measured on a site that is currently being used for motorcycle hill climbing. At the Panoche Hills site, the area used by motorcycles produced about eight times as much runoff as the unused area. Similarly, sediment yield from the used area was $857 \mathrm{~m} 3 / \mathrm{km} 2$, while the quantity of sediment from the unused area was not measurable by standard survey methods. At the Doce Spring Canyon site, which is still being used for hillclimbing, erosion surveys show that degradation in trails has been as much as $0.3 \mathrm{~m}$ in the period 1973-75. Compaction of soils and reduction of permeability appears to be the most serious hydrologic impact of motorcycle use at Panoche Hills. Increased bulk density of soils reduces depth of moisture penetration which deprives plants of moisture needed for growth.

Steiger, J. W., and R.H. Webb (2000 (PDF)). "Recovery of perennial vegetation in military target sites in the eastern Mojave Desert, Arizona." U.S Geological Survey, Open-File Report OF 00-355.

The effect of the age of geomorphic surfaces on the recovery of desert vegetation in military target sites was studied in the Mohave and Cerbat Mountains of northwestern Arizona. The target sites were cleared of all vegetation during military exercises in 1942-1943 and have not been subsequently disturbed. The degree of recovery was measured by calculating percentage similarity (PS) and correlation-coefficient indices on the basis of differences in cover, density, and volume of species growing in and out of each target site. PS values, ranging from 22.7 to 95.1 percent $(100$ percent $=$ identical composition), indicate a wide range of recovery that is partially controlled by the edaphic properties of the geomorphic surfaces. Statistical analyses show a strong pattern that indicates a greater variability in the degree of recovery for sites on older surfaces than on younger surfaces and a weak pattern that indicates an inverse relation between the degree of recovery and geomorphic age. Comparisons of the different effects of target site construction on the edaphic characteristics of each target site provides an explanation for these patterns and suggests the soil properties critical to the recovery process. Statistically significant negative or positive response to disturbance for most species are independent of the age of the geomorphic surfaces; however, there is strong evidence for a shift in response for the common perennial species Acamptopappus sphaerocephalus, and to a lesser extent, Salazaria mexicana, Encelia farinosa, and Coldenia canescens, among different geomorphic surfaces. 
Thompson, J. (1968). "Effect of grazing on infiltration in a western watershed." Journal of Soil and Water Conservation. 23(2): 63-65.

Infiltration, runoff, and erosion were measured from test plots on both grazed and ungrazed areas in the Badger Wash area in western Colorado. The area, at an altitude of about $5,000 \mathrm{ft}$, has sparse desert-type vegetation and shallow soil largely derived from weathered Mancos shale bedrock. During tests made in 1953-54, 1958, and 1963, rainfall at 5-in/hr was applied artificially to each 2.5 sq$\mathrm{ft}$ plot for a 50 -min period. The infiltration rate, measured during the last $20 \mathrm{~min}$ of the test, was about . $15 \mathrm{in} . / \mathrm{hr}$ greater for grazed than ungrazed areas, but erosion was about $18 \%$ higher on grazed areas. Infiltration rate in 1963 was only about $3 / 4$ that for 1958 in both areas although bulk density and penetrometer tests showed the soil was less compacted in 1963. It is suggested that the reduced infiltration might result from less than normal frost shrink-swell in the winter preceding 1963 and in surface compaction from above-normal summer thunderstorms. If the surface soil could be held in optimum condition, perhaps by use of wetting agents or by controlled soil cracking, normal storm rainfall of 25 to .50 in. might be held where it falls. Additional investigations in the Badger Wash area seem to be warranted.

Turner, G.T. (1971 (PDF)). "Soil and grazing influences on a salt-desert shrub range in western Colorado." Journal of Range Management: 31-37.

Responses of vegetation and ground cover to winter grazing by livestock and to exclusion of livestock for 10 years were observed on soils derived from shale, sandstone, and a mixture of shale and sandstone. Although distinct soilvegetation relationships were evident, changes attributable to grazing were relatively small. Vegetation and other cover on nongrazed range was practically the same at the end as at the beginning of the study. Overall reductions in galleta, shadscale, and snakeweed were attributed to drought, while differential responses of Salina wildrye, Gardner saltbush, Greenes rabbitbrush, and annual plants were ascribed to grazing. Inherently low site capability and subnormal precipitation were believed responsible for the general lack of response of vegetation on to exclusion of livestock.

Webb, R.H. and H.G. Wilshire, (1978 (PDF)). "An annotated bibliography on the effects of off-road vehicles on the environment". U.S. Geological Survey Open File Report 78-149, $21 \mathrm{pp}$.

This Open File Report presents a bibliography of research at the time dealing with the impact of OHV's on the environment. The papers are grouped as general papers, OHV effects on soil, OHV effects on vegetation, OHV effects on wildlife, and related abstracts. The papers cover research on impacts from OHV's across a wide array of landscapes from the Mojave Desert, to tundra. to coastal dune areas. Many of the papers looked specifically at impacts in the Mojave Desert.

Webb, R.H. (1982 (PDF)). "Off-road motorcycle effects on a desert soil." Environmental Conservation (3): 197-208.

Motorcycle use in the California Desert is a widespread and recognized management problem (Bureau of Land Management, 1980) such that an understanding of compaction under motorcycle tires is necessary in order to 
minimize the adverse effects of their use. Compaction and its effects on soil properties are widely recognized in agricultural and engineering practices but information on compaction in rangelands is generally incomplete. In this paper, the effects of an off-road motorcycle on the soil density, penetration resistance, and infiltration properties are reported for a Mojave Desert loamy sand at one moisture content, while the probable effects on different soils at varying moisture content are discussed. Four experimental trails, representing 1, 10, 100, and 200 passes each with an off-road motorcycle were established in a loamy sand at $6.2 \%$ by weight moisture content. Penetration resistance, density, infiltration rate, and response to rainfall, were measured for the undisturbed soil and for the experimental trails immediately after the conclusion of the impacts, and soil cores were measured in the laboratory to determine pore size distribution. The soil density was remeasured again one year after the impact, to determine the amount of recovery. Immediately after motorcycle use, the average density of the soil in the 0 to $60 \mathrm{~mm}$ depth increased from an average of 1.53 metric tons/cubic meter in the undisturbed soil to 1.77 metric tons/cubic meter in the 200 pass trail, and the average density in all the trails could be expressed empirically as a logarithmic function of the number of motorcycle passes. The soil penetration profile for the 200 passes trail showed that the maximum compaction occurred between 30 and $60 \mathrm{~mm}$ depth, and that changes in penetration resistance could be measured to a depth of 0.21 to $0.25 \mathrm{~m}$. The infiltration rate after 2 hours decreased from an average of $98 \mathrm{~mm} / \mathrm{hr}$ in the undisturbed soil to $29 \mathrm{~mm} / \mathrm{hr}$ in the 200 pass trail. The undisturbed soil infiltrated artificial rainfall up to an intensity of $46 \mathrm{~mm} / \mathrm{hr}$ before surface ponding occurred in the 100 and 200 pass trails at intensities greater than $25 \mathrm{~mm} / \mathrm{hr}$. Decreases in soil pore volume were greatest in pores with effective radii of greater than $150 \mathrm{um}$, with incremental; decreases occurring in pores with radii between 150 and $4.5 \mathrm{um}$; the total volumes of the smaller pores were similar in the compacted and undisturbed soils. One year after the impact, the density of the soil at a depth of $0-30 \mathrm{~mm}$ had decreased significantly in the 10,100 and 200 pass trails, but the densities at 30-60 $\mathrm{mm}$ depth remained unchanged.

Webb, R.H., and H.G. Wilshire (1983). "Environmental effects of off-road vehicles. Impacts and management in arid regions." $534 \mathrm{pp}$. Book. SpringerVerlag. New York.

This book was conceived as a result of a public meeting on the environmental effects of human uses of resources in the California Desert Conservation Area. Clearly, one of the most controversial subjects discussed at this meeting was the use of recreational off-road vehicles (ORVs) and their effects on the natural desert terrain of California. Such environmental problems, and the controversies they arouse, are found all over the world-in Australia, Canada, Spain, and Italy to name a few countries. Nonrecreational vehicles also cause adverse environmental effects in arid areas. Chief among these are military vehicles and vehicles used in exploration for minerals. Serious problems resulting from such uses have been reported from western United States, the Near-East deserts, North Africa, Peru, Australia, Russia, and China. Our purpose in publishing this book is to provide authoritative information on the physical and biological impacts of vehicles on the desert ecosystems. We then use this information to formulate general management guidelines for recreational ORV use in deserts. The chapters of this book are divided into five main categories: (1) the physical 
effects, (2) the biological effects, (3) the rehabilitation potential, (4) case histories of specific problem areas, and (5) management concepts and practices. Under physical effects, the types of soils commonly found in arid lands and their rates of formation are described (Chapter 2). These desert soils are vulnerable to modification by vehicles, and the nature of such modifications is described in Chapter 2 through 4 . The effects of these modifications on accelerating water and wind erosion are presented in Chapter 5 and 6 . Under biological effects, the vegetative communities of deserts are described, emphasis being placed on deserts of the West of the United States. The effects of ORVs on those communities are discussed in Chapters 7,8 , and 10 . The effects of vehicle noise on desert vertebrates and the general impacts of vehicles on dune fauna and flora are examined in Chapter 9 and 10 respectively. Under rehabilitation, reclamation techniques for physical systems of the desert are covered in Chapters 11 and 12, and for vegetative communities in Chapters 16 and 17 . The degree and rate of natural recovery of soils and vegetation in disturbed arid lands are described in Chapters 13 through 15. Under case histories, specific ORV problem areas in Australia and the United States are described in Chapters 18 through 20. These diverse studies illustrate the great range of adverse environmental effects caused by ORVs. Some of these effects could be anticipated; others were a surprise, thus emphasizing the need for thorough planning and careful plan implementation. The environmental effects of ORVs as described in these 20 chapters are potentially so severe, and the incompatibility of mechanical recreation with passive recreation so universal, that special planning and regulatory considerations must be applied if ORVs are to be accommodated. Management concepts and practices, including regulations, funding, and education, are covered in Chapters 21 through 23. As a consequence of the rapid escalation of recreational ORV use in the western United States in the late 1960 s and 1970 s most studies specifically related with this activity have been made in the United States, and most of this concern the California deserts. Moreover, the concepts and practices dealt with in this book are also those developed in the United States since more ORVs are used here than elsewhere in the world. However, the physical and biological effects of ORV use in arid areas are the same everywhere. Thus, the conclusions and recommendations in this book are generally applicable to arid lands throughout the world. Contributors to the book were asked to use language that was readily understood by interested laypersons, land managers, recreation planners, and policy makers. The comprehensive reference lists of important technical reports should be useful to all readers, particularly in indicating potential lines of investigation. The book is intended for use as background material for undergraduate and graduate courses in environmental and recreational planning, not merely as it applies to ORVs in the desert, but also it applies to any modification of the physical and biological resources of those lands.

Webb, R.H. (2002). "Recovery of severely compacted soils in the Mojave Desert, California, USA." Arid Land Research and Management 16(3): 291-305.

Often as a result of large-scale military maneuvers in the past, many soils in the Mojave Desert are highly vulnerable to soil compaction, particularly when wet. Previous studies indicate that natural recovery of severely compacted desert soils is extremely slow, and some researchers have suggested that subsurface compaction may not recover. Poorly sorted soils, particularly those with a loamy 
sand texture, are most vulnerable to soil compaction, and these soils are the most common in alluvial fans of the Mojave Desert. Recovery of compacted soil is expected to vary as a function of precipitation amounts, wetting-and-drying cycles, freeze-thaw cycles, and bioturbation, particularly root growth. Compaction recovery, as estimated using penetration depth and bulk density, was measured at 19 sites with 32 site-time combinations, including the former World War II Army sites of Camps Ibis, Granite, Iron Mountain, Clipper, and Essex. Although compaction at these sites was caused by a wide variety of forces, ranging from human trampling to tank traffic, the data do not allow segregation of differences in recovery rates for different compaction forces. The recovery rate appears to be logarithmic, with the highest rate of change occurring in the first few decades following abandonment. Some higher-elevation sites have completely recovered from soil compaction after 70 years. Using a linear model of recovery, the full recovery time ranges from 92 to 100 years; using a logarithmic model, which asymptotically approaches full recovery, the time required for $85 \%$ recovery ranges from $105-124$ years.

\section{DUST - WIND}

Belnap, J. and D.A. Gillette (1997 (PDF)). "Disturbance of biological soil crusts: Impacts on potential wind erodibility of sandy desert soils in southeastern Utah." Land Degradation \& Development 8(4): 355-362.

Friction threshold velocities (FTVs) were determined for biological soil crusts in different stages of recovery. Particles on the surface of crusts that had been relatively undisturbed for at least 20 years were found to have significantly higher FTVs than those that had been disturbed 5,10 or 1 years previously $(376,87$, and $46 \mathrm{~cm} \mathrm{sec}(-1)$ respectively). FTVs for crust breakage was also much higher for undisturbed crusts when compared to the previously disturbed crusts (573, 148 , and $88 \mathrm{~cm} \mathrm{sec}(-1)$ respectively). All crusted surfaces were more stable than sand, which had an FTV of $16 \mathrm{~cm} \sec (-1)$ Disturbance treatments were then applied to the three crustal classes. Disturbance significantly reduced the FTVs of all classes by 73-92 per cent. Comparing crustal FTVs with mean and high monthly wind speeds found in this region, it was observed that only crusts that had been undisturbed for approximately 20 years or more were able to protect soil surfaces from wind gusts expected on the average of once a month. Other crustal classes, as well as all disturbance treatments, had FTVs lower or equal to that of commonly occurring winds in this region. Because most of the crustal biomass occurs in the top $0.3 \mathrm{~mm}$ of soils, even slight soil loss can negatively influence stability and nutrient inputs to this ecosystem. 
Belnap, J. and D.A. Gillette (1998 (PDF)). "Vulnerability of desert biological soil crusts to wind erosion: the influences of crust development, soil texture, and disturbance." Journal of Arid Environments 39(2): 133-142.

Biological soil crusts, consisting of cyanobacteria, green algae, lichens, and mosses, are important in stabilizing soils in semi-arid and arid lands. Integrity of these crusts is compromised by compressional disturbances such as foot, vehicle, or livestock traffic. Using a portable wind tunnel, we found friction threshold velocities (FTVs) of undisturbed crusts well above wind forces experienced at these sites; consequently, these soils are not vulnerable to wind erosion. However, recently disturbed soils or soils with less well-developed crusts frequently experience wind speeds that exceed the stability thresholds of the crusts. Crustal biomass is concentrated in the top $3 \mathrm{~mm}$ of soils. Sandblasting by wind can quickly remove this material, thereby reducing $\mathrm{N}$ and $\mathrm{C}$ inputs from these organisms. This loss can result in reduced site productivity, as well as exposure of unprotected subsurface sediments to wind and water erosion. Actions to reduce impacts to these crusts can include adjustments in type, intensity, and timing of use.

Cahill, T.A., T.E. Gill, J.S. Reid, E.A. Gearhart, and D.A. Gillette (1996). "Saltating particles, playa crusts and dust aerosols at Owens (dry) Lake, California." Earth Surface Processes and Landforms 21(7): 621-639.

As part of the multinational Lake Owens Dust Experiment (LODE), we have studied the generation of dust storms on the south sand sheet of Owens (dry) Lake, California, an anthropogenically desiccated playa reported to be the single greatest source of particulate matter in North America. During March 1993, we performed an intensive field study including eight significant dust storms, building on our prior work (1978-1984) and preliminary studies (1991-1992). We studied sources and magnitude of coarse saltating particles, the meteorological conditions that allow them to become mobile across the flat playa of Owens (dry) Lake, and how the motion of saltating particles across different types of playa surfaces results in the generation of PM(10) dusts (aerosol particles smaller than $10 \mathrm{mu} \mathrm{m}$ aerodynamic diameter). Saltating grains of lacustrine sand and broken crust abrade and disaggregate the playa surface into fine aerosols, and the resulting $\mathrm{PM}(10)$ concentrations recorded during major dust storms are among the highest ever recorded in North America. On 23 March 1993, we measured a

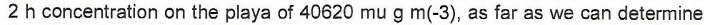
the highest ambient PM(10) value ever recorded in the U.S.A. Abrasion of saltsilt-clay crusts by saltation is shown to be responsible for all but a small part of one dust storm. The quantity 'sand run', saltating particle transport multiplied by wind run, is shown to be very closely correlated with dust aerosol concentration. Finally, we have established that on-lake bed studies are essential for quantitative prediction of dust events on the Owens (dry) Lake bed, despite the difficult conditions encountered.

Chen, W.N., D.W. Fryrear, and D.A. Gillette (1998). "Sedimentary characteristics of drifting sediments above an eroding loessal sandy loam soil as affected by mechanical disturbance." Journal of Arid Environments 39(3): 421-440.

Our understanding of the physical mechanisms of wind erosion and dust emission stimulated by disturbance of surface soils is not adequate, even though it is a problem leading to desertification in the arid zone. Simulations of the 
influence of surface soil disturbance ratios on wind erosion and sedimentary characteristics of an eroded loessal sandy loam soil were conducted in an indoor wind tunnel. The results showed that the grain-size composition of the drifting soil was finer than, though similar to, the original soil, as the surface disturbance ratio increased. Wind erosion on the loessal sandy loam soil was selective. The eroded sediments were poorly sorted and became poorer with increases in the disturbance ratio and wind speed. The relative proportion of suspension population increased with increasing disturbance ratio. Several parameters such as the pattern of the frequency distribution curves, skewness and kurtosis reflected the dependence of the sedimentary characteristics of the drifting sediments on the eroding source soil. Soil erosion and dust emission by wind in drylands can be reduced by reducing unnecessary mechanical disturbance during erosion seasons.

Fryrear, D.W. (1995). "Soil losses by wind erosion." Soil Science Society of America Journal 59(3): 668-672.

Measurements of wind erosion from fields are limited, but with recently developed erosion samplers, it is possible to determine soil losses from natural winds. Erosion of soils by wind was measured in five states. The soil loss was dependent on wind velocity, storm duration, and soil surface characteristics. Average annual rainfall varied from $356 \mathrm{~mm}$ at Eads, CO, to $915 \mathrm{~mm}$ at Crown Point, IN. Field soil varied from $29 \%$ sand at Eads, CO, to $83 \%$ sand at Big Spring, TX. Soil losses from individual erosion events in 3.1-ha fields varied from $0.050 \mathrm{~kg} \mathrm{~m}(-2)$ at Big Spring, TX, to $7.007 \mathrm{~kg} \mathrm{~m}(-2)$ at Elkhart, KS. Soil surface roughness, percentage of wind-erodible aggregates on the soil surface, and percentage of the soil surface covered with nonerodible material such as crop residues are extremely important in controlling wind erosion. A ground cover of $4 \%$ reduced wind erosion losses $15 \%$ compared with bare soil. Ridging a smooth soil with 50 - to $70-\mathrm{mm}$ ridges reduced soil erosion $98 \%$ on a sandy loam soil.

Godfrey, A.E. (1997 (PDF)). "Wind erosion of Mancos Shale badland ridges by sudden drops in pressure." Earth Surface Processes and Landforms 22(4): 345352.

One process of erosion of Mancos Shale badlands near Hanksville, Utah, appears to be caused by nearly instantaneous drops in air pressure accompanying gusts of wind. A series of sharp-crested bedrock ridges trend nearly perpendicular to the strong, gusty southwesterly winds that precede cold fronts passing through the area. The Bernoulli effect, resulting from the explosive onset of wind gusts in which the wind over the ridges can accelerate from 7 to $14 \mathrm{~m} \mathrm{~s}(-1)$, can cause nearly instantaneous pressure drops of $1.27 \mathrm{mmHg}$. This provides a unit lifting force of $0.01697 \mathrm{~N}$. Since the average gravitational force acting on a unit area of the crust is only $0.00883 \mathrm{~N}$, this force is sufficient to lift the crust, exposing the underlying weathered shale chips to further wind erosion. Soils susceptible to this type of erosion consist of polygonally cracked surface crust averaging $1.2 \mathrm{~cm}$ thick overlying a porous subsoil of silt-sized shale chips. The arid environment permits complete soil drying between weather fronts, greatly reducing the cohesion that would occur if the soil were moist. The pressure drops, and the erosion caused by them, were observed on the lee side of bedrock ridges about $10 \mathrm{~m}$ high, within $1 \mathrm{~m}$ of the ridge crest. Landforms resulting from this process are micro-cirque forms located near the ridge crests. 
Continued development of micro-cirques eventually forms cliffs on the lee sides of the ridges.

Labban, R., J. Veranth, J. Chow, J.P. Engelbrecht, and J. Watson (2004 (PDF)). "Size and Geographical Variation in PM1, PM2.5 and PM10: Source Profiles from Soils in the Western United States." Water, Air, \& Soil Pollution 157(1 - 4): 13-31. Source profiles (fractional mass abundances and uncertainties) for use in chemical mass balance (CMB) source apportionment are reported for soil dust from unpaved roads and desert lands. The objectives were to add to the library of source composition profiles available for CMB studies, and to provide data on the variation in wind-blown dust composition between particle sizes and geographical locations. Samples were resuspended and sampled through PM1, PM2.5 and PM10 inlets onto filters, then chemically analyzed for 40 elements, seven ions and eight carbon fractions. Air quality management would benefit from technology that can distinguish soil dust from sites in different geographical locations and sites with different land uses. Five geographical clusters representing Ft Bliss, TX, Dona Ana County, NM, Ft Irwin, CA, the west desert and the Canyonlands, UT, were examined. Distinctive differences were found between sites within a cluster and these differences were comparable to the differences between cluster averages. Some sites showed small differences in chemical composition between particle sizes, but these differences were less than the differences observed between nearby geographical locations. Dust emissions from sites with uniform geology have distinctive source profiles that may be useful for CMB receptor modeling. Heterogeneous regions, defined by land management boundaries, will require extensive field sampling to develop representative composite source profiles.

Mahowald, N.M. and C. Luo (2003). "A less dusty future?" Geophysical Research Letters 30(17).

Atmospheric desert dust is potentially highly sensitive to changes in climate, carbon dioxide and human land use. In this study we use 6 different scenarios of the processes responsible for changes in source areas and explore changes in desert dust loading in pre-industrial and future climates, although all the scenario results are likely to be sensitive to the climate model simulations used for this study. Simulations suggest that future dust may be 20 to $60 \%$ lower than current dust loadings. The anthropogenic portion of the current dust loading may be as large as $60 \%$, or humans may have caused a $24 \%$ decrease in desert dust, depending on the relative importance of land use, carbon dioxide and human induced climate change. These results suggest there may be a high sensitivity of 'natural aerosols' to human intervention, which has enormous implications for climate and biogeochemistry in the future.

Reynolds, R., J. Belnap, M. Reheis, P. Lamothe and F. Luiszer (2001 (PDF)). "Aeolian dust in Colorado Plateau soils: Nutrient inputs and recent change in source." Proceedings of the National Academy of Sciences of the United States of America 98(13): 7123-7127.

Aeolian dust (windblown silt and clay) is an important component in arid-land ecosystems because it may contribute to soil formation and furnish essential nutrients. Few geologic surfaces, however, have been characterized with respect to dust-accumulation history and resultant nutrient enrichment. We have 
developed a combination of methods to identify the presence of eolian dust in arid regions and to evaluate the roles of this dust in ecosystem processes. Unconsolidated sandy sediment on isolated surfaces in the Canyonlands region of the Colorado Plateau differs greatly in mineralogical and chemical composition from associated bedrock, mainly eolian sandstone. Detrital magnetite in the surficial deposits produces moderately high values of magnetic susceptibility, but magnetite is absent in nearby bedrock. A component of the surficial deposits must be eolian to account for the abundance of magnetite which formed originally in far-distant igneous rocks. Particle-size analysis suggests that the eolian dust component is typically as much as $20-30 \%$. Dust inputs have enriched the sediments in many elements, including $\mathrm{P}, \mathrm{Mg}, \mathrm{Na}, \mathrm{K}$, and $\mathrm{Mo}$, as well as $\mathrm{Ca}$, at sites where bedrock lacks calcite cement. Soil-surface biologic crusts are effective dust traps that apparently record a change in dust sources over the past several decades. Some of the recently fallen dust may result from human disturbance of land surfaces that are far from the Canyonlands such as the Mojave Desert. Some land-use practices in the study area have the potential to deplete soil fertility by means of wind-erosion removal of eolian silt.

Rice, M.A., C.E. Mullins and I.K. McEwan (1997). "An analysis of soil crust strength in relation to potential abrasion by saltating particles." Earth Surface Processes and Landforms 22(9): 869-883.

Wind erosion depends on the ease with which particles can be detached from the soil surface, but suitable tests to characterize this property are not available. Two possible methods to determine surface soil strength in the held were therefore compared on a range of artificially 'crusted' surfaces. These were made by spraying or tension wetting aggregates $(10-2,2-0.5$ and $<0.5 \mathrm{~mm})$ from a structurally unstable sandy loam, followed by drying. Each test involved measuring the force exerted on a probe driven at a steady rate into the surface, using either a flat-tipped $0.6 \mathrm{~mm}$ diameter penetrometer or a flat-ended cylindrical punch with inner and outer diameters of 5 and $6 \mathrm{~mm}$, respectively. Both probes showed that crusts could be produced reproducibly. Depending on the probe and aggregate size, penetration mainly occurred either as a result of aggregates being deflected out of the pathway of the probe or by genuine rupture of aggregates or of the crusted surface. The penetrometer, because it was comparable to the size of sand grains, gave results that can be used to characterize surface erodibility to saltating particles. The punch gave results that would be unsuitable for this purpose, as would other strength tests that are on too large a scale. Penetrometer results were analyzed to calculate the energy required for penetration. It was thus possible to demonstrate that only the spraywetted fine aggregates had a surface that could undergo large-scale rupture by saltating sand grains. For all other surfaces, saltating particles would be unable to supply sufficient energy to rupture aggregates or the crusted surface. Erosion could only occur by a slower process of abrasion in which smaller particles or aggregates are chipped away from the surface. However, it is shown that saltating particles could rupture the interaggregate bonding in the $2-0.5 \mathrm{~mm}$ aggregate surfaces, thus permitting creep. An alternative and potentially simpler way of characterizing surface erodibility by using a surface modulus of elasticity is also discussed. Our results demonstrate that the small diameter penetrometer is a promising technique for characterizing erodibility of aggregated and crusted surfaces. 
Rice, M.A., B.B. Willetts and I.K. McEwan (1996). "Wind erosion of crusted soil sediments." Earth Surface Processes and Landforms 21(3): 279-293.

Saltating particles increase the rate of dust release from sediments in arid and semi-arid areas. They also break interparticle bonds in aggregated and crusted soils, thereby increasing the number of particles available for entrainment. This pilot study examines rates of erosion in relation to the flux of saltating grains for three crusted sediments of different strengths. Dislodgement of surface particles decreases with increasing crust strength, as measured by a cylindrical flat-ended penetrometer. In addition, initial dust release from craters formed by single impactors in unaggregated soil is examined in relation to the associated saltator. The volume of material removed depends linearly on the kinetic energy of the abraders.

Selah, A. and D.W. Fryrear (1995). "Threshold wind velocities of wet soils as affected by wind blown sand." Soil Science 160(4): 304-309.

Soil moisture influences the susceptibility of a soil to wind erosion and has direct influence on the wind velocity required for initiation of soil movement (threshold wind velocity). Soil texture is another factor affecting threshold wind velocity. Threshold water content (TWC) and threshold friction velocity $\left(\mathrm{U}^{*}(\mathrm{t})\right)$ of five soils, ranging from loamy fine sand to clay, under abrading and non-abrading conditions were measured using a suction-type wind tunnel. Each soil was wetted and subjected to $8.5,10.5$, and $13 \mathrm{~ms}(-1)$ free stream wind velocities at $80 \mathrm{~mm}$ above the wind tunnel surface, with and without abrading material in the wind tunnel. Soils with higher clay content had higher water holding capacity at $1.5 \mathrm{MPa}\left(\mathrm{W}^{\prime}\right)$. Higher TWC for the same wind velocity was obtained for soils with higher $W^{\prime}$ or clay content under abrading and nonabrading conditions. All five soils required a similar wind velocity $\left(U^{*}(t)\right.$ of $0.31 \mathrm{~ms}(-1)$ for nonabrading and $0.21 \mathrm{~ms}(-1)$ for abrading conditions) to initiate their movement at oven dried condition. However, the threshold friction velocity of soils increased about $20 \%$ for 0.1 unit of equivalent threshold moisture (TWCM ') increment. Because of the erosive impact of abrading materials on soil surface, less wind $\left(U^{*}(t)\right)$ was required to initiate soil erosion with abrasion compared with nonabrading conditions. A soil with a threshold water content of $4 \%$ at the surface and $5 \%$ at $1.5 \mathrm{MPa}$ requires $\mathrm{U}^{*}(\mathrm{t})$ of $0.646 \mathrm{~ms}(-1)$ under nonabrading and $0.596 \mathrm{~ms}(-1)$ under abrading conditions to start eroding wet, loose erodible materials at the soil surface eroded when abrading materials were introduced in the wind tunnel. Predictive equations were developed from which TWC and $U^{*}(t)$ could be predicted, based on soil physical properties.

Singer, M.J. and I. Shainberg (2004 (PDF)). "Mineral soil surface crusts and wind and water erosion." Earth Surface Processes and Landforms 29(9): 1065-1075.

The first few millimeters of soil largely control the soil's response to the eroding forces of wind and water. The tendency of soils to form surface seals and crusts influences the processes of wind and water erosion differently. For wind, dry particle size distribution and particle organization determine the shear strength and threshold wind velocity necessary to initiate particle movement. In loams and clay loams, seals and crusts decrease roughness but increase surface soil strength, generally decreasing wind erosion. Conversely, in sand and sandy loams, loose erodible sandy material may either deposit on the crust and is 
subject to erosion or it may disrupt the crust, accelerating the erosion process. For water erosion, particle size distribution and structure determine infiltration rate, time to ponding, and energy required for soil particle detachment. Seals and crusts tend to decrease infiltration rate and time to ponding thus increasing overland flow and soil erosion. This paper briefly reviews how permanent and time-dependent soil properties influence surface seals and crusts and how these affect soil erosion by wind and water. The tendency of a soil to form a seal and crust depends to some degree on the time-dependent property of soil structural stability, which tends to increase with increasing clay content and smectitic mineralogy which are permanent properties. These permanent properties and their effect on structure are variable depending on dynamic properties of exchangeable sodium percentage and soil solution electrical conductivity. Antecedent water content prior to irrigation or rainfall, rate of wetting before an erosive event and aging, the time between wetting and an erosive event, greatly influence the response of soil structure to raindrop impact. The effect of these dynamic processes is further influenced by the static and dynamic properties of the soil. Weak structure will be less influenced by wetting rate than will a soil with strong structure. Process-based models of wind and water erosion need to consider the details of the interactions between soil static and dynamic properties and the dynamic processes that occur prior to erosive events.

\section{RECLAMATION - RESTORATION}

Amemiya, M., C.W. Robinson, and E.W. Coley (1955 (PDF)). "Reclamation of a saline-alkali soil in the upper Colorado River Basin." Soil Science Society of America Journal $20: 423-426$.

An experiment to determine the feasibility of reclaiming an unproductive salinealkali calcareous soil (Billings silty clay loam) in the upper Colorado River Basin was established near Grand Junction, Colo. The effects of leaching and gypsum on the reclamation of this soil, which is typical of the soils of the upper Colorado River Basin, were followed by periodic soil analysis and by measuring the yield of alfalfa. The amounts of soluble salts and exchangeable sodium in the soil were materially decreased by the leaching treatments. This decrease was a function of the amount of water used to leach the soil. From 4 to 6 feet of water were required to reclaim such soils to a depth of 50 inches. Gypsum application in combination with leaching had little or no effect on reducing exchangeable sodium. After cropping with alfalfa for 1 year, soluble salts and exchangeable sodium adversely affected the yield of alfalfa where only 2 feet of water were used to reclaim. There are indications that salts and exchangeable sodium may be re-accumulating in the profile. Soil differences attributable to different reclamation treatments significantly affected the yield of alfalfa. Plots leached with 6 feet of water yielded 5.15 tons of hay per acre, as compared with 4.37 tons per acre obtained from plots leached with only 2 feet of water. Yield differences were attributed to differences in the chemical and physical properties of the soil which resulted from the reclamation treatments. 
Davidson, D.W., M. Bowker, D. George, S.L. Phillips, and J. Belnap (2002). "Treatment effects on performance of $\mathrm{N}$-fixing lichens in disturbed soil crusts of the Colorado Plateau." Ecological Applications 12(5): 1391-1405.

Biological soil crusts arrest soil erosion and supply nitrogen to ecosystems. To understand their recovery from disturbance, we studied performances of Collema $\mathrm{spp}$. lichens relative to four experimental treatments plus microtopography of soil pedicels, oriented north-northwest to south-southeast in crusts. At sites in Needles (NDLS) and Island in the Sky (ISKY) districts of Canyonlands National Park, lichens were transplanted to NNW, SSE, ENE, WSW, and TOP pedicel faces and exposed to a full-factorial, randomized block experiment with four treatments: nutrient addition ( $\mathrm{P}$ and $\mathrm{K}$ ), soil stabilization with polyacrylamide resin (PAM), added cyanobacterial fiber, and biweekly watering. After $14.5 \mathrm{mo}$ (NDLS) and 24 mo (ISKY), both visual rankings of lichen condition and measures of chlorophyll fluorescence were generally higher at ISKY than on more fertile but less stable soils at NDLS. On ENE and NNW pedicel faces, both these values and nitrogenase activity (NDLS only) exceeded corresponding values on WSW and SSE faces. Treatment effects were site specific and largely negative at NDLS; both nutrient and cyanobacterial addition led to poorer lichen condition, and added nutrients led to reduced fluorescence, Responses to nutrients may have been mediated partly by disturbance of unstable soils and by competition with cyanobacteria. In a separate experiment investigating recruitment responses to adding fungal spores or Nostoc cells, rates of Collema establishment responded significantly to the former but not the latter. Low establishment overall suggests that natural recruitment may occur mainly from iscidia or thallus fragments not spores. Measured simultaneously on artificial soil pedicels at NDLS and ISKY, both deposition and erosion declined at NDLS across the four pedicel microaspects as: WSW > SSE > NNW > ENE (or ENE > NNW), during fall and spring trials. Patterns were similar at ISKY, but WSW SSE for spring deposition, and deposition did not differ by microaspect in fall. Greater deposition at ISKY, despite higher abundance of cyanobacteria, may be explained by stronger wind velocities. Together, microtopographic differences in erosion, microclimate, and nutrient regimes help explain variable lichen performance, but microtopography influenced lichen performance more consistently than did any treatment. Demonstrated effects of pedicel development in crust recovery concur with prior surveys showing greatest microbial biomass and/or cover on ENE and NNW exposures at various spatial scales.

Flanagan, D.C., K. Chaudhari, and L.D. Norton (2002 (PDF)). "Polyacrylamide soil amendment effects on runoff and sediment yield on steep slopes: Part I. Simulated rainfall conditions." Transactions of the ASAE 45(5): 1327-1337.

Steep slopes consisting of disturbed soil are very often found in construction, landfill, and surface mining situations. Although legislation and economics dictate that vegetative cover be established on these slopes as rapidly as possible, the occurrence of large rainfall events during critical periods of vegetation establishment can frequently cause extensive soil loss. Sediment generated from erosion can impair off-site water quality, and on-site damages to the eroded, region can be so extensive that expensive earthmoving, regrading, reseeding, and remulching may be necessary. We evaluated the effectiveness of two soil treatments for reducing runoff and. soil loss from a silt loam topsoil placed on a constructed $32 \%$ slope. The three treatments were an untreated control, $80 \mathrm{~kg}$ 
ha(-1) anionic polyacrylamide (PAM) applied as a liquid spray, and $80 \mathrm{~kg}$ ha(-1) $\mathrm{PAM}$ as a liquid spray combined with a dry granular application of $5 \mathrm{Mg} \mathrm{ha(-1)}$ of gypsum. Replicated plots were subjected to a range of rainfall intensities under a programmable rainfall simulator, and resulting runoff and sediment loss were measured. In the first event of $69 \mathrm{~mm} h(-1)$ uniform rainfall applied for one hour to initially dry soil, the PAM and PAM with gypsum treatments significantly reduced runoff by almost $90 \%$ and sediment yield by $99 \%$, compared to the control. Total runoff through a series of simulated rainfall events was reduced by $40 \%$ to $52 \%$, and sediment loss was reduced by $83 \%$ to $91 \%$ for the plots treated with PAM and PAM plus gypsum, respectively. These results indicate that the use of PAM alone or in combination with gypsum can significantly reduce runoff and soil loss from large storm events, and may be a cost-effective approach to protect the soil during critical periods of vegetation establishment, particularly for disturbed soils on steep slopes.

Flanagan, D.C., K. Chaudhari, and L.D. Norton (2002 (PDF)). "Polyacrylamide soil amendment effects on runoff and sediment yield on steep slopes: Part II. Natural rainfall conditions." Transactions of the ASAE 45(5): 1339-1351.

Soil loss from embankments at highway construction sites, sanitary landfills, and elsewhere can be extremely large due to the loosened state of the soil and very steep slope gradients (typically $2: 1$ to $3: 1$ ). Soil amendments have the potential to protect the soil during critical periods of vegetation establishment, thus reducing on-site damages and costs as well as reducing off-site impacts on water quality. In Part I of this study, results from a rainfall simulator experiment showed that use of an anionic polyacrylamide (PAM) could significantly reduce runoff and soil loss under the extreme condition of a large rainfall event occurring immediately after PAM application. In this part of the study, the same soil amendment treatments were tested in field situations on steep slopes under natural rainfall, to determine PAM effectiveness for typical constructed embankment conditions. One experiment was conducted on a highway cutslope on a clay loam subsoil placed at a $35 \%$ slope. The second experiment was in a surface sanitary landfill on a filled silt loam topsoil placed at a $45 \%$ slope, typical of a landfill cap. The soil amendment treatments used were an untreated control, an application of $80 \mathrm{~kg} \mathrm{ha(-1)}$ anionic polyacrylamide (PAM) as a liquid spray, and $80 \mathrm{~kg}$ ha(-1) PAM applied as a liquid spray combined with a dry granular application of $5 \mathrm{Mg} \mathrm{ha(-1)}$ of gypsum. A barrel collection system was used to measure total runoff volume and sediment loss. Total soil loss over all events at the two experiment site for plots treated with PAM was reduced in the range of $40 \%$ to $54 \%$, compared to the control. The addition of gypsum had a significant effect on runoff volume only on the silt loam soil, possibly due to higher rainfall at that site and/or to the presence of substantial amounts of calcium in the clay loam subsoil at the other location. PAM and PAM with gypsum increased grass establishment and growth on treated plots-compared to the control. These results indicate that the use of anionic polyacrylamide (with or without gypsum) can provide substantial benefits in reducing runoff and soil loss, and enhancing vegetation growth on very steep embankments.

Heller, H. and R. Keren (2002 (PDF)). "Anionic polyacrylamide polymers effect on rheological behavior of sodium-montmorillonite suspensions." Soil Science Society of America Journal 66(1): 19-25. 
Polyacrylamide (PAM) is a long-chain synthetic polymer that acts as a strengthening agent, binding clay particles together. The interaction between anionic PAM and clay particles is not well understood yet. This interaction was evaluated by rheological measurements for Na-montmorillonite suspensions. Three anionic PAMs of three molecular weights (MWs) (3.5 X 10(3), $2 \times 10(5)$, and $8 \times 10(6) \mathrm{g} \mathrm{mol}(-1))$ at similar hydrolysis levels $(>85 \%)$ and three anionic PAMs at various degrees of hydrolysis $(\mathrm{DH})(15,33$, and $92 \%)$ of similar MW were studied. In an electrolyte-free clay suspension at $\mathrm{DH}>85 \%$, only the polymers with high MWs $(2 \times 10(5)$, and $8 \times 10(6))$ could form a threedimensional structure of clay platelets. The smallest polymer molecule size ( 3.5 X 10(3)) was too short for bonding two adjacent platelets. At similar MW, the effect of the polymers increased with $\mathrm{DH}$. At $\mathrm{NaCl}$ concentration of $10 \mathrm{mmol}(\mathrm{c}) \mathrm{L}$ 1 , at which the attractive forces between clay platelets were weak, the polymers had a significant impact on flow behavior. The effectiveness of the polymers increased with increasing $\mathrm{MW}$ and $\mathrm{DH}$. At $\mathrm{NaCl}$ concentration of $100 \mathrm{mmol}(\mathrm{c}) \mathrm{L}$ 1 , the three polymers of $\mathrm{DH}>85 \%$ stabilized flocs that already existed in the clay suspension. The effectiveness of the polymers in bridging adjacent clay floes increased as their DH decreased. The polymer conformation factor has a greater impact on clay structure stabilization in suspension than the electrostatic repulsion effect. The clay structure stability was increased with increasing polymer electrostatic negative charge for similar molecular weights.

Jaynes, R.A. and K.T. Harper. (1978 (PDF)). "Patterns of natural revegetation in arid Southeastern Utah." Journal of Range Management 31(6): 407-411. Current and pending legislation will require that lands disturbed by mining activities be revegetated. Since few adapted species are now available for reclamation of such lands in the arid zone, this study was initiated to identify native species that are successful colonizers of disturbed sites. The native vegetation of bladed roadways in the Kane County, Utah, was sampled to identify natural colonizer species. Sixteen successful colonizers have been identified and studied to determine (1) their relative colonizing efficiency, and (2) their individual responses to elevation, soil textural, and other environmental gradients. The species fall into two natural groups: one group is well adapted to lower benchlands with sandy clay loam soils and the other is adapted to upper benchlands with sandy loam soils. Some of the species that appear to be most successful in initially revegetating disturbed areas include: (1) upper benchlandsIndian ricegrass, galleta grass, sand aster, pepperweed, broom snakeweed, small leaf scarlet globemallow, and blue locoweed; (2) lower benchlandsshadscale, desert molly, cut-leaf globemallow, and pink locoweed.

Malik, M., C. Amrhein, and J. Letey (1991 (PDF)). "Polyacrylamide to improve water-flow and salt removal in a high shrink-swell soil." Soil Science Society of America Journal (6): 1664-1667.

Reclamation of salt-affected high shrink-swell soils using chemical amendments combined with deep loosening and tile drainage is very expensive. As an alternative, the utilization of cracks as pathways for water and salts is possible if these cracks could be stabilized by the application of a polyacrylamide (PAM) polymer and their complete closure prevented upon rewetting. A laboratory column study was conducted on two soil samples with exchangeable sodium percentages (ESP) of 8 and 25 from a heavy-textured, swelling soil. The soil 
samples were packed into columns, ponded with irrigation water for $24 \mathrm{~h}$, then drained and dried to create cracks. After drying, the soil samples were ponded for $24 \mathrm{~h}$ with irrigation water containing $0,25,75$, and $200 \mathrm{mg} \mathrm{L}-1$ of an anionic polyacrylamide polymer, allowed to drain, and dried. The treated soils were then ponded without drainage for $1,6,12$, and $24 \mathrm{~h}$ to allow crack closure and the hydraulic conductivity $(\mathrm{HC})$ and effluent salinity were measured. The experiment was repeated except that the polymer solution was added to the soil without initially creating the cracks. An additional study was carried out to test the durability of the polymer when subjected to wetting and drying cycles. Increasing the amount of polymer significantly increased the $\mathrm{HC}$ and salt removal in the cracked soils. When the polymer solution was applied directly onto soils without initially creating cracks, there was no increase in HC on the ESP 8 soil and a small increase on the ESP 25 soil. The polymer had a stabilizing effect on soil cracks, but the increase in $\mathrm{HC}$ did not persist through several wetting and drying cycles.

Peterson, J.R., D.C. Flanagan, and J.K. Tishmack (2002 (PDF)). "Polyacrylamide and gypsiferous material effects on runoff and erosion under simulated rainfall." Transactions of the Asae 45(4): 1011-1019.

An indoor laboratory study was conducted to compare the dry versus sprayed application of polyacrylamide (PAM) and the use of different gypsiferous materials (gypsum and a class $\mathrm{C}$ ponded fly ash) on runoff and sediment yield. The six treatments incorporated in this study were: control, Nutra-Ash (NA), gypsum (G), sprayed PAM plus NA (PAMW+NA), sprayed PAM plus $G$ $(P A M W+G)$, and granular PAM plus $G(P A M D+G)$. Simulated rainfall at an intensity of $70 \mathrm{~mm} \mathrm{hr}(-1)$ was applied for 2 hours to a silty clay loam soil packed into erosion pans. Only one of the two liquid PAM treatments (PAMW+G) significantly reduced runoff $(35 \%)$, while both liquid PAM treatments (PAMW+G and PAMW+NA) significantly reduced sediment yield ( $74 \%$ and $77 \%$ ) compared to the control. Sprayed PAM was more effective than granular application in terms of total runoff, but there was no statistical difference with regard to total sediment yield. Differences between the effects of sprayed and granular PAM are explained by the mechanisms by which they reduce erosion. Sprayed PAM, in combination with gypsum, increases infiltration during the first part of a rainfall event until sufficient rainfall has occurred to break down the PAM-treated aggregates, at which time runoff rate and sediment yield rate approach those of the control. Runoff and sediment yield rates from the granular PAM application were initially similar to those from the control. However, as time increased, sediment yield reached a maximum and then decreased without a corresponding decrease in runoff. This likely occurred because the PAM particles became activated during the rainfall and acted as a mortar to stabilize the soil matrix. Gypsum was a better source of electrolyte than a class C ponded fly ash, commercially known as Nutra-Ash (NA), likely due to its greater solubility. Addition of PAM decreased soil erodibility and may be a viable erosion control practice for soils susceptible to flow detachment. Choice of application method should be based on the expected amount and severity of precipitation before vegetation establishment. These results indicate that sprayed PAM, in combination with gypsum or Nutra-Ash, provides immediate erosion control, but its effectiveness decreases over time, as indicated by steadily increasing sediment yield rate. Dry PAM application was not as effective in the beginning of 
the experiment, but after sufficient rainfall it became "activated" and sediment yield continuously decreased over the remainder of the experiment.

Peterson, J.R., D.C. Flanagan, and J.K. Tishmack (2002 (PDF)). "PAM application method and electrolyte source effects on plot-scale runoff and erosion." Transactions of the Asae 45(6): 1859-1867.

Previous research has indicated that polyacrylamide (PAM) soil amendments can be effective in reducing runoff and soil erosion by reducing soil sealing and stabilizing soil structure. Furthermore, the application of a multivalent electrolyte $(\mathrm{Ca}++)$ in addition to PAM has been shown to further reduce runoff volume and sediment yield on some soils. A field study was conducted using simulated rainfall to test the effectiveness of the method of PAM application (dry or in solution) and the effectiveness of two sources of $\mathrm{Ca}++$ electrolytes. Treatments using an application of a liquid PAM solution that was allowed to dry on the soil surface were the most effective in reducing total runoff $(62 \%$ to $76 \%$ reduction compared to control) and total sediment yield (93\% to $98 \%$ reduction compared to control). Spraying of PAM in solution was significantly more effective in controlling runoff and erosion than was the dry granular application for the rainfall events simulated in this study. The slope of regressing sediment yield rate on runoff rate was used as a measure of erodibility. Sprayed PAM treatments dramatically reduced erodibility compared to the control. Dry PAM application also reduced soil erodibility compared to the control, but not as dramatically as the sprayed PAM. For intense rainstorms on initially dry soil, we recommend using a sprayed application of PAM for the best erosion control. More research is needed to determine whether this holds true for less intense storms under different field conditions.

Reeves, F.B., D. Wagner, T. Moorman, and J. Kiel (1979 (PDF)). "The role of endomycorrhizae in revegetation practices in the semiarid west: A comparison of incidence of mycorrhizae in severely disturbed vs. natural environments." Amer. J. Boot. 66(1): 6-13.

A comparison of a natural, undisturbed ecosystem, a mid-elevation sage community, with a severely disturbed old roadbed through this community revealed that more than $99 \%$ of the plant cover in the natural community was mycorrhizal (vesicular-arbuscular), whereas less than $1 \%$ of the plant cover in the disturbed area (roadbed) was mycorrhizal. Examples of nonmycorrhizal plants as primary successional species in severely disturbed habitats are discussed. The importance of maintaining or re-establishing the mycorrhizal fungal components in reclamation programs designed to produce stable ecosystems is emphasized.

Robinson, C. (1968). "Reclamation of saline-sodic soils in the upper Colorado River Basin." Source Colorado State University Experiment Station, Bulletin 535S, Mar 1968. 19 p. 11 Fig. 1 Tab.

Below-average yields in arid and semi-arid lands may be due to accumulation of soluble salts and alkaline soils. Sodic soils commonly become abandoned. The irrigated Grand Valley of western Colorado has 20,000 acres of below-average crop production. The Mancos Shale, parent material for soil, contains highly saline groundwater--electrical conductivity of $9.0 \mathrm{mmhos} / \mathrm{cm}$ in the shallow gravel aquifer, and more than $100 \mathrm{mmhos} / \mathrm{cm}$ in saturated soil pastes. Sodium, calcium, 
and magnesium chlorides and sulfates accumulate and may be leached to reclaim soils by additional irrigation. Soil amendments and salt tolerance are discussed. Pump drainage lowers the water table to reclaim soils efficiently. Pumping at 250 to 300 gallons per minute after 15 months lowered the water table about 2 feet in 150 to 200 acres with significant wheat and corn production improvement. Over irrigation and pump drainage proved a successful rehabilitation method for saline-sodic soils in the upper Colorado River Basin. A table shows effects of leaching treatments on soluble salt content and exchangeable sodium percentages of soil. Eleven figures show general topography of study area, typical fields of reclaimed and abandoned land, leaching effects conductivities, yields and crop response.

\section{VEGETATION - SOIL CRUSTS - INVASIVES}

Anderson, J.L. and J.M. Porter (1994). "Astragalus tortipes (Fabaceae), a New Species from Desert Badlands in Southwestern Colorado and its phylogenetic relationships within Astragalus." Systematic Botany 19(1): 116-125.

Astragalus tortipes is a new species from the southern flank of Sleeping Ute Mountain in southwestern Colorado that grows with mixed desert scrub on Mancos Shale badlands overlain by pediment gravel. Based on phylogenetic estimations using parsimony, the new species is placed as a member of Barneby's sect. Lonchocarpi subsect. Lonchocarpi and is compared morphologically to other astragali, Astragalus tortipes is characterized by its hyper-reflexed pod, a character unique in North American Astragalus.

Anderson, J.L., J.L. Reveal, and R.C. Rollins (1997). "Lesquerella vicina (Brassicaceae), a new species from the Uncompahgre River valley in Western Colorado." Novon 7(1): 9-12.

Lesquerella vicina (Brassicaceae) is proposed for a perennial with white flowers found near Montrose, Colorado. It is most closely related to the yellow-flowered L. rectipes, differing additionally by having broader basal leaves. In the Montrose area it grows on Mancos Shale from 6000 to 7200 feet at the ecotone between pinyon-juniper woodland and salt desert scrub. At the lower elevation the plants have a more ephemeral growth form, but at the higher elevations the plants are longer-lived perennials with well-developed caudices.

Bashkin, M., T.J. Stohlgren, Y. Otsuki, M. Lee, P. Evangelista, and J. Belnap (2003). "Soil characteristics and plant exotic species invasions in the Grand 
Staircase - Escalante National Monument, Utah, USA." Applied Soil Ecology 22(1): 67-77.

The Grand Staircase-Escalante National Monument (GSENM) contains a rich diversity of native plant communities. However, many exotic plant species have become established, potentially threatening native plant diversity. We sought to quantify patterns of native and exotic plant species and cryptobiotic crusts (mats of lichens, algae, and mosses on the soil surface), and to examine soil characteristics that may indicate or predict exotic species establishment and success. We established 97 modified-Whittaker vegetation plots in 11 vegetation types over a 29,000 ha area in the Monument. Canonical correspondence analysis (CCA) and multiple linear regressions were used to quantify relationships between soil characteristics and associated native and exotic plant species richness and cover. CCA showed that exotic species richness was significantly $(P<0.05)$ associated with soil $P(r=0.84)$, percentage bare ground $(r=0.71)$, and elevation $(r=0.67)$. Soil characteristics alone were able to predict 41 and $46 \%$ of the variation in exotic species richness and cover, respectively. In general, exotic species invasions tend to occur in fertile soils relatively high in C, $\mathrm{N}$ and $\mathrm{P}$. These areas are represented by rare mesic high-elevation habitats that are rich in native plant diversity. This suggests that management should focus on the protection of the rare but important vegetation types with fertile soils.

Belnap, J. and S. L. Phillips (2001). "Soil biota in an ungrazed grassland: Response to annual grass (Bromus tectorum) invasion." Ecological Applications 11(5): 1261-1275.

Bromus tectorum is an exotic annual grass that currently dominates many western U.S. semi-arid ecosystems, and the effects of this grass on ecosystems in general, and soil biota specifically, are unknown. Bromus recently invaded two ungrazed and unburned perennial bunchgrass communities in southeastern Utah. This study compared the soil food-web structure of the two native grassland associations (Stipa [S] and Hilaria $[\mathrm{H}]$ ), with and without the presence of Bromus. Perennial grass and total vascular-plant cover were higher in $S$ than in $\mathrm{H}$ plots, while quantities of ground litter were similar. Distribution of live and dead plant material was highly clumped in $\mathrm{S}$ and fairly homogenous in $\mathrm{H}$. Soil food-web structure was different between $\mathrm{H}$ and $\mathrm{S}$, with lower trophic levels more abundant in $\mathrm{H}$ and higher trophic levels more abundant in $\mathrm{S}$. In Bromus-invaded plots. the quantity of ground litter was 2.2 times higher in Hilaria-Bromus (HB) than in $\mathrm{H}$ plots, and 2.8 times higher in Stipa-Bromus (SB) than in S plots. Soil biota in HB generally responded to the Bromus invasion in an opposite manner than in SB, e.g., if a given component of the food web increased in one community, it generally decreased in the other. Active bacteria decreased in $\mathrm{H}$ vs. HB, while increasing in S vs. SB. Soil and live plant-infecting fungi were the exception, as they increased in both types of invaded plots relative to uninvaded plots. Dead-plant-infecting fungi decreased in $\mathrm{H}$ vs. $\mathrm{HB}$ and increased in $\mathrm{S}$ vs. SB. Most higher-trophic-level organisms increased in $\mathrm{HB}$ relative to $\mathrm{H}$, while decreasing in SB relative to $S$. Given the mixed response to invasion, the structure of these soil food webs appears to be controlled by both plant inputs and internal dynamics between trophic levels. When compared to non-invaded sites, soil and soil food-web characteristics of the newly invaded sites included: (1) lower species richness and lower absolute numbers of fungi and invertebrates; (2) greater abundance of active bacteria; (3) similar species of 
bacteria and fungi as those found in soils invaded over $50 \mathrm{yr}$ ago; (4) higher levels of silt (thus greater fertility and soil water-holding capacity); and (5) a more continuous cover of living and dead plant material (thus facilitating germination of the large-seeded Bromus). These results illustrate that (1) soil food-web structure can vary widely within what would generally be considered one vegetation type (semi-arid grassland), depending on plant species composition within that type, and (2) addition of a common resource can evoke disparate responses from individual food-web compartments, depending on their original structure.

Bestelmeyer, B.T., J.E. Herrick, J.R. Brown, D.A. Trujillo, and K.M. Havstad (2004 (PDF)). "Land management in the American Southwest: A state-andtransition approach to ecosystem complexity." Environmental Management 34(1): 38-51.

State-and-transition models are increasingly being used to guide rangeland management. These models provide a relatively simple, management-oriented way to classify land condition (state) and to describe the factors that might cause a shift to another state (a transition). There are many formulations of state-andtransition models in the literature. The version we endorse does not adhere to any particular generalities about ecosystem dynamics, but it includes consideration of several kinds of dynamics and management response to them. In contrast to previous uses of state-and-transition models, we propose that models can, at present, be most effectively used to specify and qualitatively compare the relative benefits and potential risks of different management actions (e.g., fire and grazing) and other factors (e.g., invasive species and climate change) on specified areas of land. High spatial and temporal variability and complex interactions preclude the meaningful use of general quantitative models. Forecasts can be made on a case-by-case basis by interpreting qualitative and quantitative indicators, historical data, and spatially structured monitoring data based on conceptual models. We illustrate how science- based conceptual models are created using several rangeland examples that vary in complexity. In doing so, we illustrate the implications of designating plant communities and states in models, accounting for varying scales of pattern in vegetation and soils, interpreting the presence of plant communities on different soils and dealing with our uncertainty about how those communities were assembled and how they will change in the future. We conclude with observations about how models have helped to improve management decision-making.

Bleak, A.T., N.C. Frischknecht, A. Perry Plummer, and R.E. Eckert, JR. (1962 (PDF)). "Problems in artificial and natural revegetation of the arid shadscale vegetation zone of Utah and Nevada'." Journal paper No. 364, Utah Agricultural Experiment Station.

Vast areas of the arid shadscale zone have been rehabilitated through management, but direct plantings of both native and introduced species usually have failed. Future success will likely be with native plants, including shrubs, adapted to the particular site. Returns from revegetation of lands in the shadscale zone are low contrasted with those in the sagebrush zone. Many problems were encountered in the shadscale zone, but the arid climate appeared to be the major factor. Average annual precipitation ranged from 3 to more than 8 inches. Droughts were general throughout the zone. Low humidity, high evaporation, and high diurnal temperature fluctuations increased the severity of 
the climate. The heterogeneous soils in the shadscale zone usually contained more soluble salts than comparable soils in the sagebrush zone. Although vast areas have been rehabilitated through management, direct plantings of both introduced and native species usually failed. Good seedling stands usually were obtained with the wheat grasses, but most plants perished during the first summer. A few plantings of the introduced crested wheatgrass, fairway wheatgrass, Siberian wheatgrass, and Russian wildrye maintained stands for 10 or more years. Although resident shrubs and grasses dominated the various communities within the zone, good stands were difficult to obtain by artificial seeding. Low seed viability and seed dormancy were problems. Since seeds of many native and introduced species germinated at relatively low temperatures in late winter and early spring, frost damage occurred. Seedlings of native shrubs usually were not highly drought resistant and frequently perished during the first year. Site differences coupled with inherent differences between strains of a single species may have limited adaptability of these strains to specific localities. In addition, insects, rabbits, and rodents ravished the depleted land in some years. Success in this arid zone will likely depend on use of native plants adapted to the particular site. Future revegetation efforts should include the use of native shrubs which dominate the natural communities within this zone.

Duda, J.J., D.C. Freeman, J.M. Emlen, J. Belnap, S.G. Kitchen, J.C. Zak, E. Sobek, M.Tracy, and J. Montante (2003 (PDF)). "Differences in native soil ecology associated with invasion of the exotic annual chenopod, Halogeton glomeratus." Biology and Fertility of Soils 38(2): 72-77.

Various biotic and abiotic components of soil ecology differed significantly across an area where Halogeton glomeratus is invading a native winterfat, [Krascheninnikovia (=Ceratoides) lanata] community. Nutrient levels were significantly different among the native ecotone, and exotic-derived soils. NO3, P, $\mathrm{K}$, and $\mathrm{Na}$ all increased as the cover of halogeton increased. Only $\mathrm{Ca}$ was highest in the winterfat area. A principal components analysis, conducted separately for water-soluble and exchangeable cations, revealed clear separation between halogeton- and winterfat-derived soils. The diversity of soil bacteria was highest in the exotic, intermediate in the ecotone, and lowest in the native community. Although further studies are necessary, our results offer evidence that invasion by halogeton alters soil chemistry and soil ecology, possibly creating conditions that favor halogeton over native plants.

Evans, R.D., R. Rimer, L. Sperry, and J. Belnap (2001). "Exotic plant invasion alters nitrogen dynamics in an arid grassland." Ecological Applications 11(5): $1301-1310$.

The introduction of normative plant species may decrease ecosystem stability by altering the availability of nitrogen $(\mathrm{N})$ for plant growth. Invasive species can impact $\mathrm{N}$ availability by changing litter quantity and quality, rates of $\mathrm{N}$-2-fixation, or rates of $\mathrm{N}$ loss. We quantified the effects of invasion by the annual grass Bromus tectorum on $\mathrm{N}$ cycling in an arid grassland on the Colorado Plateau (USA). The invasion occurred in 1994 in two community types in an undisturbed grassland. This natural experiment allowed us to measure the immediate responses following invasion without the confounding effects of previous disturbance. Litter biomass and the $\mathrm{C}: \mathrm{N}$ and lignin: $\mathrm{N}$ ratios were measured to determine the effects on litter dynamics. Long-term soil incubations ( $415 \mathrm{~d}$ ) were 
used to measure potential microbial respiration and net $\mathrm{N}$ mineralization. Plantavailable $\mathrm{N}$ was quantified for two years in situ with ion-exchange resin bags, and potential changes in rates of gaseous $\mathrm{N}$ loss were estimated by measuring denitrification enzyme activity. Bromus invasion significantly increased litter biomass, and Bromus litter had significantly greater $\mathrm{C}: \mathrm{N}$ and lignin: $\mathrm{N}$ ratios than did native species. The change in litter quantity and chemistry decreased potential rates of net $\mathrm{N}$ mineralization in sites with Bromus by decreasing nitrogen available for microbial activity. Inorganic N was $50 \%$ lower on Hilaria sites with Bromus during the spring of 1997, but no differences were observed during 1998. The contrasting differences between years are likely due to moisture availability; spring precipitation was $15 \%$ greater than average during 1997 , but $52 \%$ below average during spring of 1998 . Bromus may cause a shortterm decrease in $\mathrm{N}$ loss by decreasing substrate availability and denitrification enzyme activity, but $\mathrm{N}$ loss is likely to be greater in invaded sites in the long term because of increased fire frequency and greater $\mathrm{N}$ volatilization during fire. We hypothesize that the introduction of Bromus in conjunction with land-use change has established a series of positive feedbacks that will decrease $\mathrm{N}$ availability and alter species composition.

Fowler, N. (1986 (PDF)). "The role of competition in plant communities in arid and semiarid regions." Ann. Rev. Ecol. Syst. 17: 89-110.

The importance, and even the existence, of competition among plants in arid ecosystems has often been questioned. An influential statement of Shreve asserted that interspecific competition does not occur in deserts, and Went denied that competition between desert plants occurs at all. Neither provided evidence for his assertions, although Shreve pointed out the diversity of habits and phenologies found among desert species. He may have been responding to the strong emphasis placed on competition by Clements and his followers. The importance of competition in natural communities has recently been debated. These reviews suggested that terrestrial plant communities are among the communities in which competition is relatively important. However, the majority of studies upon which this conclusion is based were made in humid regions. Grime suggested that competition is less important in "high stress" habitats (in which he included dry habitats), but he presented little evidence from arid or semiarid environments. This paper reviews the available evidence for competition in plant communities in arid and semiarid regions; as is demonstrated, competition certainly occurs in these communities and involves many different species. In several instances it appears to be important in the determination of community structure. Competition may be less frequent in these communities, though not less important on that account. This review also addresses several other questions concerning the role of competition in these communities, including: the role of competition in determining the absence, or presence and abundance, of species in a community, and their spatial arrangement; which species are in competition with one another; and at which stages in the life cycle they experience competition. In addition, I review current knowledge of the mechanisms of competition and the ways in which plants partition niches in these communities, as well as facilitation of one plant by another, and succession. Finally, potential directions of future work are discussed. 
Garcia-Pichel, F., S.L. Johnson, D. Youngkin, and J. Belnap (2003). "Small-scale vertical distribution of bacterial biomass and diversity in biological soil crusts from arid lands in the Colorado Plateau." Microbial Ecology 46(3): 312-321.

We characterized, at millimeter resolution, bacterial biomass, diversity, and vertical stratification of biological soil crusts in arid lands from the Colorado Plateau. Microscopic counts, extractable DNA, and plate counts of viable aerobic copiotrophs (VAC) revealed that the top centimeter of crusted soils contained atypically large bacterial populations, tenfold larger than those in uncrusted, deeper soils. The plate counts were not always consistent with more direct estimates of microbial biomass. Bacterial populations peaked at the immediate subsurface $(1-2 \mathrm{~mm})$ in light-appearing, young crusts, and at the surface $(0-1$ $\mathrm{mm}$ ) in well-developed, dark crusts, which corresponds to the location of cyanobacterial populations. Bacterial abundance decreased with depth below these horizons. Spatially resolved DGGE fingerprints of Bacterial 16S rRNA genes demonstrated the presence of highly diverse natural communities, but we could detect neither trends with depth in bacterial richness or diversity, nor a difference in diversity indices between crust types. Fingerprints, however, revealed the presence of marked stratification in the structure of the microbial communities, probably a result of vertical gradients in physicochemical parameters. Sequencing and phylogenetic analyses indicated that most of the naturally occurring bacteria are novel types, with low sequence similarity (83$93 \%$ ) to those available in public databases. DGGE analyses of the VAC populations indicated communities of lower diversity, with most types having sequences more than $94 \%$ similar to those in public databases. Our study indicates that soil crusts represent small-scale mantles of fertility in arid ecosystems, harboring vertically structured, little-known bacterial populations that are not well represented by standard cultivation methods.

Hodgkinson, H. S. (1987). "Relationship of saltbush species to soil chemicalproperties." Journal of Range Management 40(1): 23-26.

The relationship of pure stands of 6 saltbush species to sodium adsorption ratio [SAR], electrical conductivity [EC], and alkalinity are documented. The data gathered were obtained while correlating soils to range sites for National Cooperative Soil Surveys. Soil scientists gathered detailed soil information and obtained lab data. Range conservationists correlated the saltbush species to specific soils and by using lab data made a direct relationship to pure saltbush stands. Species ranked from highest to lowest adaptability to SAR, EC, and $\mathrm{pH}$ are: mat saltbush (Atriplex corrugata $S$. Wats.), mound saltbush (A. obovata Mog.), Castle Valley clover (A. cuneata A. Nels.), sickle saltbush (A. falcata (M. E. Jones) Standl.), shadscale (A. confertifolia (Torr. and Frem.) S. Wats.) and fourwing saltbush (A. canescens (Pursh) Nutt.). By knowing the SAR, EC, and $\mathrm{pH}$ tolerances of these 6 species, interpretations for inventorying, rating plant community potentials, and applying range improvements will be achieved with greater success.

Potter, L.D., R.C.J. Reynolds, and E.T. Louderbough (1985). "Mancos Shale and plant community relationships analysis of shale soil and vegetation transects." Journal of Arid Environments 9(2): 147-166.

Analyses of an extensive collection of Mancos shale and derived soils from the western United States showed pH values from 3.4 to 9.4 , sulfate concentrations 
high and widely distributed, and soil solution equilibria of gypsum and sodiumdominated smectite important to soil salinity. In situ soils show little change in $\mathrm{pH}$, conductivity, sulfate, GSI (gypsum saturation index), or sodium values with respect to the shales from which they were derived. On slopes, vegetative sequences from big sagebrush or blackbrush to shadscale to mat saltbush to greasewood are related to increases of sulfate. Galleta grass is also restricted by high sulfate values. The blackbrush to shadscale transition is related to sodium increase. Mat saltbush was found in soils with 17,685 ppm sodium (saturated soil solution) and $4350 \mathrm{ppm}$ sulfate (1:5 extract).

Potter, L.D., R.C.J. Reynolds, and E.T. Louderbough (1985). "Mancos Shale and plant community relationships field observations." Journal of Arid Environments 9(2): 137-146.

Field observations were made of associated vegetational communities during an extensive program of collection of Mancos shale samples and derived soils. Vegetative responses in the same climate regime were related to physical and chemical variations of the shale. Sulfuric acid, formed by the oxidation of sulfur compounds, either lowers $\mathrm{pH}$ or forms calcium sulfate by alteration of calcium carbonate. Partial dissolution of calcium sulfate results in the formation of sodium sulfate and an ion exchange equilibrium with sodium-dominated smectite is attained. The most mesic vegetation occurs when sandstone fragments cap, or are mixed with, Mancos shale soils. Leaching and transport of weathered shale also removes inhibitive aspects of the Mancos shale materials and favors good vegetational development. 


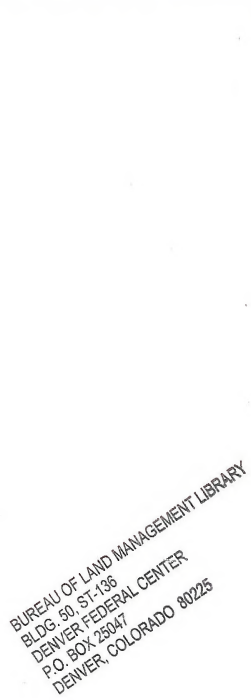

I

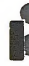




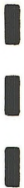

I

I

I

I

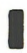

I

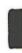

I

,

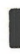

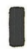

I

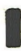

I

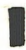

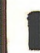


